\title{
APORTACIONES AL ESTUDIO DE LA MÚSICA EN LA SANTA CAPILLA DE SAN ANDRÉS DE JAÉN DURANTE EL SIGLO XVI: DOS JUEGOS DE VERSOS PARA MINISTRILES DE GIL DE ÁVILA (FL. 1574-1597)*
}

\author{
CONTRIBUTIONS TO THE STUDY OF MUSIC AT THE SANTA CAPILLA OF \\ SAN ANDRÉS IN JAÉN DURING THE 16TH CENTURY: TWO SETS OF VERSES \\ FOR MINSTRELS BY GIL DE ÁVILA (FL. 1574-1597)
}

Javier Marín-López

Universidad de Jaén marin@ujaen.es

ORCID iD: https://orcid.org/0000-0003-3337-5565

Virginia Sánchez-López

Universidad de Jaén

vsanchez@ujaen.es

ORCID iD: https://orcid.org/0000-0003-2619-7502

José A. Gutiérrez-Álvarez

Universidad Complutense de Madrid

jotonogutierrez@hotmail.com

ORCID iD: https://orcid.org/0000-0002-3229-9321

Pedro Jiménez-Cavallé

Universidad de Jaén

pjimenez@ujaen.es

ORCID iD: https://orcid.org/0000-0002-1959-2507

\begin{abstract}
Resumen
En el año 2015 se conmemora el quinto centenario de la fundación en Jaén de una importante cofradía adscrita a la iglesia parroquial de San Andrés y conocida con el nombre de Santa Capilla. Lo que diferencia a esta hermandad de otras creadas en la España de la época es la presencia, estatutariamente establecida, de una capilla de música con el propósito de enaltecer sus celebraciones religiosas. El presente artículo ofrece un estudio panorámico sobre la Santa Capilla como institución musical durante el siglo XVI, basándose en nuevos hallazgos archivísticos. El trabajo incluye un análisis de los modelos de mecenazgo que pudo tener en mente su fundador, el protonotario apostólico Gutierre González Doncel; una revisión crítica de las actividades musicales de cantores, instrumentistas y maestros de capilla al servicio de la cofradía; algunas hipótesis sobre el repertorio musical empleado; y un estudio específico, acom-
\end{abstract}

\begin{abstract}
2015 marks the 500th anniversary of the foundation in Jaén of a major confraternity attached to the parish church of San Andrés and known as Santa Capilla. What differentiates this brotherhood of others created in Spain at the time is the bylaws established presence of a music chapel in order to exalt its religious celebrations. This article offers a panoramic study of the Santa Capilla as a musical institution during the 16th century, based on new archival findings. The work includes an analysis of models of patronage that its founder, the Apostolic Protonotary Gutierre González Doncel, might have in mind; a critical review of the musical activities of singers, instrumentalists and chapelmasters at the service of the institution; some hypotheses about the repertoire used; and a specific study, accompanied by the critical edition, of two interesting sets of verses for minstrels by Gil de Ávila, the only pieces preserved by the only
\end{abstract}

* Deseamos expresar nuestro agradecimiento a las autoridades de la Santa Capilla de San Andrés y del Archivo Histórico Diocesano de Jaén (España), y de la Catedral de Puebla (México) por las facilidades dadas para la realización de esta investigación. 
pañado de la edición crítica, de dos singulares juegos de versos para ministriles de Gil de Ávila, únicas piezas del único maestro de la Santa Capilla del siglo XVI del que conocemos música.

\section{Palabras clave}

Santa Capilla de San Andrés (Jaén), Gutierre González Doncel, mecenazgo musical, capilla de música, circulación de música y músicos, Gil de Ávila, versos para ministriles, Catedral de Puebla (México). 16th-century chapelmaster of the Santa Capilla with known musical production.

\section{Keywords}

Santa Capilla of San Andrés (Jaén), Gutierre González Doncel, musical patronage, music chapel, circulation of music and musicians, Gil de Ávila, verses for minstrels, Puebla cathedral (Mexico).

Pues siempre ha habido en Jaén perfectísimos músicos de voces muy estimadas así en su iglesia como en las más ricas y principales del Reino para donde cada día salen con salarios aventajados por la calidad que tienen consigo de ser naturales del lugar que tanto nombre tiene en todas partes ${ }^{1}$.

En 1515, hace justo 500 años, Gutierre González Doncel funda en la iglesia parroquial de San Andrés de Jaén una cofradía a la advocación de la Inmaculada Concepción conocida como Santa Capilla. Lo que distingue a esta hermandad de otras creadas en la España de la época es que sus estatutos recogían de manera expresa la creación de una capilla de cantores con el propósito de enaltecer las celebraciones religiosas y enseñar música no sólo a los mozos de coro y ministros de la institución, sino a todas aquellas personas interesadas en aprenderla. Pero junto a este uso estrictamente funcional, como motor solemnizador de la liturgia, el fundador incorporó la música también como manifestación de su riqueza y símbolo de su propio estatus y distinción. González seguía así un modelo de mecenazgo de las artes y la educación musical plenamente establecido en Italia que él conocía de primera mano y que respondía a la perfección al ideal humanista expresado por diversos teóricos desde el siglo XV y condensado por Baltasar de Castiglione en su difundido tratado El cortesano (1528): la música como atributo indispensable de príncipes y gobernantes. Al establecer un conjunto musical estable en una humilde parroquia, su fundador instauraba la primera capilla polifónica adscrita a una institución eclesiástica en el Santo Reino, anterior cronológicamente a la de la propia catedral.

Con este trabajo pretendemos desarrollar estos aspectos, subrayando la singularidad de este modelo de mecenazgo en el contexto hispano de la época, y reconstruyendo algunos hitos de la actividad y los músicos en la Santa Capilla durante el siglo de su fundación. El archivo de papeles de música de San Andrés se destruyó en su integridad, lo cual nos impide analizar el proyecto de González en toda su dimensión, es decir, no sólo como iniciativa institucional sino como generador de un repertorio con funciones simbólicas reflejo de los ideales del fundador. Una excepción en este panorama la constituyen dos juegos de versos instrumentales para ministriles del itinerante maestro de capilla Gil de Ávila, que presentamos en transcripción moderna y que constituyen la única muestra musical conocida del siglo XVI de un compositor al servicio de la Santa Capilla. La conservación de estas piezas en la Catedral de Puebla de los Ángeles (México) sirve asimismo como ejemplo de la proyección de los repertorios musicales de la metrópoli en el Nuevo Mundo, donde llegó no sólo el Libro de la doctrina christiana del benefactor sino también la música compuesta por algunos de los maestros de su institución.

\section{GUTIERRE GONZÁLEZ DONCEL Y EL MECENAZGO MUSICAL EN LA ROMA PRETRIDENTINA}

Todo personaje ilustre, como el que protagoniza este aniversario, es hijo de su época reflejándose en él, de alguna manera, las peculiaridades que la definen. El jiennense $\mathrm{Gu}-$ tierre González Doncel (ca. 1468-1529) no fue una excepción a ello y, tras haber recibido en Roma (1489) la primera tonsura de clérigo por el obispo de Salamanca, Diego Meléndez Valdés, y ostentar algunos cargos eclesiásticos en la diócesis de Jaén, se estableció en la Ciudad Eterna en 1502 e inició una ascendente carrera eclesiástica en los círculos humanistas de la curia bajo la protección de Julio II (papa entre 1503-1513) y León X (1513-1521), a los que sirvió en diversos cargos. Este último le nombró en 1517 protonotario apostólico, dignidad con honores de prelacía que le permitió conocer causas y asuntos por delegación de Su Santidad; se sumaba así a la nutrida colonia de castellanos que ocuparon puestos destacados en la administración papal en esa época, entre los que destacaba un connotado paisano, el cardenal Esteban Gabriel Merino.

Nada más insertarse en la corte pontificia, González comienza a recibir una larga serie de beneficios eclesiásticos 
en Sevilla, Córdoba y Jaén, cuyas rentas le permitieron acometer, en consonancia con la mentalidad piadosa de la época, la fundación en 1515 de una obra pía en una de las capillas de la iglesia parroquial de San Andrés de Jaén, de la que era prior. Se trataba de una cofradía de advocación inmaculista, denominada Noble Cofradía de la Limpia Concepción de Nuestra Señora ${ }^{2}$. En los estatutos se mencionaban los fines fundamentales de esta institución religioso-benéfica (casar doncellas, vestir pobres y enseñar niños) y se contemplaba la creación de una capilla de música (entendida aquí como conjunto estructurado de cantores e instrumentistas profesionales). El fundador justificaba su presencia por la importancia de la música como elemento solemnizador del culto: "porque una de las cosas que principalmente adorna y multiplica la devoción del culto divino es la música concertada"3. La presencia de una agrupación de músicos como ornato del rito no resulta sorprendente, ya que la polifonía era un elemento característico de la identidad de las élites religiosas de la época, lo que dio lugar al establecimiento de capillas estables desde finales del siglo XV en todas las catedrales españolas, muchas colegiatas y algunas parroquias de alto rango. Sin embargo, interpretar la instauración de la capilla musical desde una perspectiva estrictamente litúrgico-funcional nos haría perder de vista la dimensión cultural e ideológica de la fundación, una práctica simbólica de ejercicio del poder que, además de dotar al patrono de supuestos beneficios espirituales, le permitía proyectar su prestigio entre sus conciudadanos y perpetuar su memoria entre las generaciones futuras ${ }^{4}$.

Este modelo de mecenazgo musical de origen humanístico estaba plenamente establecido en cortes italianas como Mantua, Ferrara o Florencia (además de en la propia curia romana) y se materializó de diversas formas: la contra-

2 Entre la bibliografía más relevante sobre esta institución y su fundador se cuentan los siguientes trabajos: MOZAS MESA, Manuel, 1925; GARCÍA DE QUESADA y MARTÍNEZ, Manuel, 1950; GONZÁLEZ LÓPEZ, Luis, 1960: 2119-23; ORTEGA SAGRISTA, Rafael, 1961: 23-63; HIGUERAS MALDONADO, Juan, 1985: 241-302; CABALLERO VENZALÁ, Manuel y ALMANSA TALLANTE, Rufino, 2009: 526-533; y LÓPEZ PÉREZ, Manuel, en prensa. El más reciente y completo estudio es la importante tesis de LÓPEZ ARANDIA, María Amparo, 2007.

3 Archivo Histórico Diocesano de Jaén (AHDJ), Cofradías, leg. sin signatura, «Estatutos de la Cofradía de la Purísima Concepción», manuscrito, $¿ 1512$ ?, tratado $2^{\circ}$, cap. XI, f. $22 \mathrm{v}$. En este trabajo, en el que hemos optado por modernizar la transcripción y puntuación de los textos, utilizamos la tercera edición impresa de 1882 (hubo ediciones anteriores en 1674 y 1712): Libro de los Estatutos de la Santa Capilla y Noble Cofradía de la Limpia Concepción de Nuestra Señora la Virgen María, sita en la Iglesia Parroquial de San Andrés. Madrid, Imprenta de D. A. Pérez Dubrull, 61. Véase JIMÉNEZ CAVALLÉ, Pedro, 1987: 10. 4 Sobre las implicaciones simbólicas, antropológicas y semióticas del mecenazgo musical, véase ANNIBALDI, Claudio, 1993: 9-43. tación de músicos (de manera eventual o estable), el apoyo a la edición de libros de música (que luego eran dedicados a los protectores), la propia práctica musical o el coleccionismo de instrumentos y partituras (hábito muy extendido entre la aristocracia y el alto clero). Bajo este sistema de patronazgo subyacía la idea de que príncipes y gobernantes debían poseer una cultura musical amplia y ser capaces de tañer no sólo las piezas simples, sino también madrigales y composiciones complejas, pudiendo cantar en conjunto o recitar acompañándose de un instrumento, siguiendo la práctica del "cantar por vihuela" que requería Juan Boscán, o del «cantare alla viola» que relata Castiglione en El cortesano ${ }^{5}$. No se debe olvidar, por otra parte, que en la concepción neoplatónica característica del Renacimiento, la música tenía un positivo efecto en el alma y era la única disciplina que merecía el nombre de "originaria del cielo", según señalaba, entre otros, Marsilio Ficino en su De amore $^{6}$. En este contexto no sorprende el protagonismo cultural de la música durante los siglos XV y XVI, que viene a coincidir con una eclosión en lo que a consumo de repertorio polifónico se refiere, a lo que también contribuyó en buena medida la invención de la imprenta musical.

Desconocemos las razones últimas que llevaron a González a establecer una capilla de música en su cofradía, ya que lo más frecuente tanto en Italia como en España era que estas instituciones de carácter gremial, sacramental o penitencial no tuviesen agrupaciones propias, acudiendo a la contratación de capillas externas para cubrir sus necesidades musicales y solemnizar las principales festividades de su calendario litúrgico anual ${ }^{7}$. ¿Respondería al modelo que Annibaldi denomina "mecenazgo convencional", en el sentido de establecer una capilla musical de patrocinio privado para cumplir con la red de expectativas y aspiraciones de la época, expresando así su poder y riqueza?, ¿o estaríamos ante un caso de patronazgo propiamente humanístico, reflejo del interés personal, experiencia musical y buen gusto del patrón? Ambas manifestaciones de mecenazgo no son incompatibles y, en el caso de González, pudo confluir el doble deseo de expresar su estatus y su propia sensibilidad artística. Carecemos de evidencias concretas sobre la relación de González con la música, más allá de la formación musical general que recibiría como eclesiástico en Roma. En su Historia de la antigua y continuada nobleza de la ciudad de Jaén (1628), Bartolomé Jiménez Patón incluyó una referencia a González como "buen cantor", si bien lo hizo en un tono metafórico y en el marco de una fantasiosa descripción del supuesto mar-

5 VEGA, María José, 2007: 296.

6 Ibídem, 282. Véase también QUEROL, Miguel, 1988: 213225; y ROBLEDO, Luis, 1998: 385-430.

7 BEJARANO PELLICER, Clara, 2013: 472-489. 
tirio del fundador durante el Saco de Roma ${ }^{8}$. El hecho de que el Libro de la doctrina christiana (1532; reed. 1564) de González no incluya ejemplos musicales o referencias explícitas a la enseñanza de la música no implica necesariamente que esta disciplina no formase parte de su proyecto educativo, como se ha venido sosteniendo ${ }^{9}$. Por un lado, los estatutos de la Santa Capilla establecen claramente -como veremos más adelante- que los mozos de coro debían recibir instrucción musical; por otro, es altamente probable que, al igual que ocurría con otros catecismos del siglo XVI como los de Andrés Flórez (1546) o Juan de Ávila (1554), el aprendizaje de los preceptos contenidos en el Libro de la doctrina christiana de González se realizase al son de sencillas melodías que, a modo de contrafacta, ayudaban a memorizar las coplas a los niños ${ }^{10}$; así ocurriría no sólo en la Santa Capilla (donde obviamente está documentado el volumen) sino también en otros lugares de España y de las Indias, donde el libro del protonotario gozó de gran popularidad ${ }^{11}$. Todos estos aspectos invitan a aplicar a González con total propiedad el calificativo de mecenas de la música, labor que canalizó a través de su obra pía, dotándola de los ingresos y bienes raíces necesarios para sustentar un grupo de músicos. Ello nos descubre un perfil hasta ahora no suficientemente valorado en esta emblemática figura, pero que encaja a la perfección con el ambiente de humanismo religioso en el que se desenvolvió.

El modelo de capilla musical adoptado en la Santa Capilla no sería el proveniente de la Catedral de Jaén, que en la temprana fecha, ya citada, de 1515, no existía o, al menos, no está probado documentalmente; no será hasta 1536 cuando se crearía la ración de maestro de capilla de la seo jiennense, existiendo hasta entonces sólo una ración de cantor creada en 1505 con obligación de enseñar "canto figurado" a seis niños ${ }^{12}$. Ello convierte a la fundación de San Andrés -con la documentación conocida hoy- en la primera capilla polifónica estable adscrita a una institución eclesiástica en

8 JIMÉNEZ PATÓN, Bartolomé, 1628: ff. 88r-v: "En estas obras y tormentos no se olvidó como buen cantor de entonar la tercera voz en el verso que entonó primero el maestro de capilla de la Iglesia, Cristo, y después metió el segundo en voz el protomártir Esteban, y triplicándole dijo una y muchas veces: 'Señor, perdona a estos pobres hombres [...]"”.

9 LÓPEZ ARANDIA, María Amparo, 2007: 394.

10 DE VICENTE, Alfonso, 2007.

11 Archivo Histórico de la Santa Capilla de San Andrés de Jaén (AHSCSAJ), leg. 10, “Cuentas Hacienda 1531-1543”, Libro de cuentas $1531-1543$, f. $114 \mathrm{v}$, descargo de 1535 , registra un pago de cincuenta maravedís al librero Antonio de Medina por la encuadernación del Libro de la doctrina christiana. Sobre la difusión de este libro en México gracias a la labor del obispo Vasco de Quiroga, véase LÓPEZ ARANDIA, María Amparo, 2010: 129-147.

12 AHDJ, leg. sin signatura, Informe de la ración de cantor 14771767; y JIMÉNEZ CAVALLÉ, Pedro, 2007: 328-329. el Santo Reino, anterior cronológicamente a la de la propia catedral; sólo la capilla del Condestable Lucas de Iranzo, de carácter cortesano, se adelantó a ella en pleno siglo $\mathrm{XV}^{13}$. Por tanto, los modelos de referencia que González tendría en mente no estarían en Jaén sino en Roma, donde residió más de veinticinco años. Este largo periodo de tiempo le permitiría contactar y conocer de cerca las tipologías de patronazgo musical no sólo del papado, sino también de los múltiples centros romanos con los que pudo mantener relación, en especial iglesias (entre ellas la de Santiago de los Españoles o el Hospital de Santo Espíritu) y cofradías (Annunziata, Divino Amor, Concepción, Caridad o del Popolo). Parece evidente que nos hallamos ante una imitación (consciente o inconsciente) de modelos de mecenazgo conocidos de primera mano por González en Roma y posteriormente traslados y adaptados a un nuevo contexto.

La etapa de mayor poder de González en la Ciudad Eterna coincidió con el periodo de Giovanni de Medici, conocido como León X. Como ya señaló hace décadas André Pirro, Giovanni recibió una exquisita educación musical bajo la tutela de los destacados maestros que su padre, Lorenzo el Magnífico, tenía a su servicio en la corte de Florencia $^{14}$. Siendo un excelente cantante y rodeado de música desde su niñez, no resulta extraño que, al ser nombrado papa, elevase el número de cantores de la capilla pontificia hasta los treinta, señalase a un compositor como cabeza visible del coro (Elzéar Genet, conocido como Carpentras), apoyase la publicación de libros de música y contratase un importante conjunto de músicos para su servicio privado, los llamados «cantores e musici secreti» ${ }^{15}$. En lo que respecta a la capilla papal, es necesario recordar que sus interpretaciones en la mítica Cappella Sistina se realizaban totalmente «a cappella» con uno o dos cantantes por parte y sin acompañamiento instrumental alguno, lo que hacía que las plazas fueran muy competidas. Precisamente uno de los aspectos más destacados del pontificado de León X consistió en la masiva incorporación de cantores españoles -la mayoría sopranos falsetistas- que trajeron consigo prácticas peninsulares y un estilo de canto "a la manera española" muy valorado en la interpretación de lamentaciones y pasiones ${ }^{16}$. En este auge de la presencia de cantantes hispanos (algunos de los cuales fueron también compositores) pudo tener un papel relevante Esteban Gabriel Merino, a quien se dirigían las solicitudes

13 Ibídem, 327 y ss. Véase también GÓMEZ MUNTANÉ, Maricarmen, 1996: 25-45; y KNIGHTON, Tess, 1997: 661-677.

14 PIRRO, André, 1935: 1-16.

15 Sobre este último aspecto, véase BLACKBURN, Bonnie, 1992: 1-37.

16 SHERR, Richard, 1992: 601-609. 
de admisión de los músicos que aspiraban a ser miembros de la capilla papal de León X y de su antecesor Julio $\mathrm{II}^{17}$. Desconocemos si su mención era simplemente institucional o si, por el contrario, asumió un rol efectivo en la selección. Aunque no se han localizado evidencias documentales sobre la carrera de Merino como músico, resulta revelador que en la biografía de León X escrita por Angelo Fabronio y publicada en 1797, se señalase que fue la pericia vocal de Merino la que le hizo merecedor del obispado de Bari ${ }^{18}$.

Entre los cantores de la «nación española» con quien González coincidió en Roma estaban los compositores Juan Escribano, cantor papal entre 1502 y 1539, y Andreas de Silva, músico al servicio privado de León X entre 1519 y 1521 , de probable (pero no confirmado) origen español ${ }^{19}$. El compositor y dramaturgo Juan del Encina gozó de la protección de sucesivos papas y cardenales (en particular de Alejandro VI y del cardenal Francisco Loriz) entre 1500 y 1518. Aunque Encina no consta nominalmente como cantor de la Cappella Sistina en ningún momento, formó parte de la corte papal en la que también se desenvolvía González, y fácilmente pudieron conocerse ${ }^{20}$. Quizá el más importante músico español en Roma en la época de González fue el toledano Francisco de Peñalosa, quien antes de servir como cantor papal (1517-21), trabajó en la capilla real aragonesa al servicio de Fernando el Católico (1498-1516), regresando después a ocupar una canonjía en la Catedral de Sevilla, donde murió en 1528, el mismo año en que veía la luz un destacado maestro hispalense relacionado con Jaén: Francisco Guerrero. No se conservan obras de Peñalosa en archivos italianos, pero el repertorio transmitido en fuentes ibéricas (integrado sobre todo por misas, motetes y magnífcats) evidencia una depurada técnica contrapuntística deudora de las tendencias compositivas internacionales ${ }^{21}$. La muerte de González en 1529 le impidió conocer al compositor ibérico más renombrado de la siguiente generación, Cristóbal de Morales, quien trabajó como cantor

17 Ibídem, 608.

18 FABRONIUS, Angelo, 1797: 26-27: "Ea propter minime reverens reprehensiones prudentiorum, uno eodemque die Jacobus Gherardum Volterranum qui praesulum Romanorum acetate \& sapientia decus \& Lumen erat Segninum episcopum, \& Gabrielem Merinum Hispanum cujus tantummoda nota erat in psallendo et canendo peritia, Barii archiepiscopum creavit" (el énfasis es nuestro).

19 Véase LLORENS CISTERÓ, José María, 1957: 96-122; y KIRSCH, Winfried, 2001.

20 SHERR, Richard, 1982: 159-172.

21 Dos de los principales libros con música de Peñalosa son el Ms. 2/3 de la Catedral de Tarazona [E:TZ 2/3] (de probable origen sevillano) y el Cancionero Musical de Palacio [E: $M p$ 1335] (este último para su obra en castellano); véase KNIGHTON, Tess, 2002: 231-257. Véase la edición de su obra latina a cargo de PRECIADO, Dionisio, 1986-1991. papal durante diez años (1535-45), periodo durante el cual publicó varias obras de gran influencia, como sus magníficats o sus dos libros de misas ${ }^{22}$. Sí coincidió, en cambio, con Josquin des Prez, quien llegó a Roma el mismo mes y año que González recibió la tonsura clerical allí (junio de 1489); Josquin permaneció como cantor de la capilla papal al menos hasta noviembre de 1494, si bien en esos años el joven clérigo jiennense no tenía aún ningún peso en la curia pontificia, por lo que lo más probable es que no tuvieran una relación directa ${ }^{23}$.

Aunque la capilla del papa era el centro musical de mayor prestigio de Roma (en realidad de toda la cristiandad), un nutrido conjunto de iglesias contaban con capillas de música de manera permanente, tales como la Cappella Giulia de San Pedro, las basílicas de San Juan de Letrán, Santa María la Mayor y las iglesias de San Lorenzo en Dámaso, Santa María en Vallicella (conocida como Chiesa nuova), y San Luis, esta última iglesia nacional de los franceses ${ }^{24}$. También consta la presencia de grupos musicales a lo largo del siglo XVI en seminarios jesuitas como el Collegio Germanico (para el que trabajó Tomás Luis de Victoria) y el Collegio Inglese y en las iglesias nacionales que aragoneses y castellanos tenían en Roma, Santa María de Montserrat y Santiago, que constituían el punto de encuentro de la comunidad de españoles ${ }^{25}$. A diferencia de lo que ocurría en la capilla papal, donde sólo había cantores, en estas otras iglesias se ha documentado la contratación de capillas integradas por un nutrido conjunto de instrumentos.

En el caso romano, el cultivo de la polifonía sacra se vio notablemente enriquecido por las numerosas cofradías que contrataban anualmente a músicos para sus fiestas y procesiones. Aunque no existen estudios sistemáticos sobre la actividad musical de las fraternidades romanas en tiempos de González, la presencia de la música en sus prácticas devocionales cotidianas era constante, si bien limitada -según apuntan todas las evidencias- al canto $1 \mathrm{lano}^{26}$. En las festivi-

22 Otros músicos españoles residentes en Roma, ya de la segunda mitad del siglo XVI, serán Tomás Luis de Victoria (activo en distintas instituciones entre 1565 y 1585) y el castrado Francisco Soto de Langa (cantor papal entre 1562 y 1611).

23 González regresó a Jaén en algún momento de la década de 1490, pues en 1497 figura como prior de la parroquia de San Pedro de Jaén, según LÓPEZ ARANDIA, María Amparo, 2007: 268-269. La pérdida de los registros de pago de la Cappella Sistina entre 1495 y 1500 impide determinar hasta qué año sirvió Josquin; véase STARR, Pamela F., 1997: 43-65

24 Véase SHERR, Richard, 2001.

25 Sobre la actividad musical de esta última institución en tiempos de González, véase PIETSCHMANN, Klaus, 1999: 451-476.

26 BLACK, Christopher F., 1989: 272. Un caso excepcional se daba en Venecia, donde las ricas cofradías o scuole grandi sí que disponían de capillas de música propias durante el siglo XVI; véase GLIXON, Jonathan, 2003. 
dades más importantes de las hermandades, en cambio, consta la contratación de capillas de música (a veces referidas simplemente como "música"), un fenómeno en permanente expansión a lo largo del siglo XVI, en particular tras el impulso dado por el Concilio de Trento a estas agrupaciones como forma de sacralización de los hábitos cotidianos. Los estudios sobre las cofradías de la Trinidad de los Pellegrini, San Rocco o la Resurrección demuestran la importancia de estos colectivos en la vida pública, su proyección urbana y su importante labor de patronazgo musical, desvelando relaciones de intercambio y colaboración entre ellas ${ }^{27}$. La cofradía de la Resurrección, fundada en la iglesia española de Santiago, desplegó una actividad musical de notable importancia en las fiestas del Corpus Christi y Pascua, en las que a finales del siglo XVI llegaron a participar más de cincuenta cantores procedentes de casi todas las iglesias de Roma ${ }^{28}$. González, a quien suponemos dotado de una fina sensibilidad para captar todo lo que ocurría en su entorno, no podría permanecer ajeno a la importancia de la música en el sistema productivo romano, gracias al que escucharía repertorio polifónico de manera cotidiana, ya fuera en las cristalinas interpretaciones «a cappella» del coro papal o en las más nutridas versiones con acompañamiento instrumental patrocinadas por iglesias y fraternidades. El conocimiento de estas exuberantes prácticas polifónicas, unido a la ausencia de una capilla reglada en la catedral (donde le negaron el establecimiento de su obra pía), pudo llevarle a establecer un conjunto musical específico para su Santa Capilla.

\section{CANTORES E INSTRUMENTISTAS, DOS COLECTIVOS AL SERVICIO DE LA SANTA CAPILLA}

Tanto en los estatutos de la cofradía como en las sucesivas bulas y breves pontificios que González envió desde Roma se contempla la creación de diversos puestos para el gobierno de la Santa Capilla. Entre los ministros y oficiales que habían de servir en su fundación se menciona en el Proemio a "ciertos cantores, un tañedor de órganos, un sacristán, cuatro mozos de coro", sujetos todos ellos al Gobernador y Consiliarios $^{29}$. El capítulo XI del tratado II, dedicado específicamente a los cantores, concreta que serán "cuatro cantores instructos [sic] en canto de órgano, de los cuales el uno será principal, o maestro de capilla" ${ }^{30}$. Aunque las bulas de la

27 Sobre las dos primeras, véase O’REGAN, Noel, 1994: 521552; y del mismo autor, 1995.

28 O'REGAN, Noel, 1994: 286.

29 Libros de los Estatutos, 39.

30 Libros de los Estatutos, 57. institución hablan de este número de cantores, no prohíben "poner cinco, de los cuales el uno de ellos será maestro de capilla, al cual podrán mejorar en salario, según la calidad y habilidad suya" ${ }^{31}$. Estos cantores, que cubrían los principales registros vocales a uno por cada parte (tiple, contralto, tenor y bajo), se designaban de manera directa o tras la correspondiente oposición y tenían la obligación de asistir a la Santa Capilla con la vestimenta adecuada (sobrepellices los clérigos y hábitos los legos) los Domingos, días de fiesta "de guardar" y otras fiestas celebradas con solemnidad, participando en Misa y primeras y segundas Vísperas.

El capítulo XII se dedica al organista (llamado "tañedor de órganos"), cargo instituido expresamente "para solemnizar el culto divino y ayudar a los oficios de ella" ${ }^{32}$. A diferencia del salario de los cantores y del maestro de capilla, limitado a un monto total máximo de 100 ducados de oro (o 37.500 maravedís) al año, la paga del organista sería similar a la que le diese la parroquia de San Andrés (donde se intuye que ya existía el cargo), pudiendo aumentar su salario a discreción de la Santa Capilla sin superar los 3.000 maravedís y seis fanegas de trigo cada año. El órgano tenía un papel preponderante en las funciones de la Santa Capilla y muchas de las asistencias del organista eran comunes a las de los cantores: domingos y fiestas de guardar (igualmente a Misa y primeras y segundas Vísperas), sábados a la Misa de alba y Vísperas, y lunes a la Misa de los ángeles. Se incluye en este capítulo una curiosa prescripción ceremonial a propósito del Credo, que en la Santa Capilla se interpretaba con especial solemnidad, pausado y nunca con el órgano (por importante que fuera la fiesta), a no ser que se hiciese "a verso cantado con el órgano", es decir, "muy pronunciado por algún buen cantor un verso y respondiendo con otro verso en el coro" ${ }^{33}$.

El capítulo XIV se dedica a los mozos de coro, que servían de ayudantes de los sacerdotes en las misas. Su número quedó fijado en cuatro (pudiendo aumentarse a seis) y su salario en dos ducados (750 maravedís) para cada uno, quedando obligados a recibir enseñanza de "canto llano y canto de órgano" (por los cantores) y gramática (por el preceptor) ${ }^{34}$. En contraste con lo que ocurría en muchas catedrales, no parece que existiera en San Andrés una diferencia terminológica entre mozos de coro (generalmente versados en canto llano

\section{Ibídem.}

32 Libros de los Estatutos, 58-59.

33 Libros de los Estatutos, 58.

34 Libros de los Estatutos, 60-61. Dicho salario se mantenía para los cuatro mozos activos veinte años después, aunque en 1595 se había triplicado; véase AHSCSAJ, leg. 10, "Cuentas Hacienda 1531-1543", Libro de cuentas 1531-1543, f. 107r, descargo de 1535; leg. 12, "Cuentas Hacienda 1590-1604", Libro de cuentas 1590-1604, sin foliar (s.f.), descargo de 1595. 
y bajo la tutela de un maestro de mozos o del sochantre), y seises (al cuidado del maestro de capilla y responsables de cantar las partes de tiple en la polifonía). La Santa Capilla se convirtió, junto con la Catedral de Jaén, en un importante semillero de niños cantores que eran reclamados en toda Andalucía, según indica la documentación de otras instituciones del entorno andaluz y confirma la cita de la anónima Historia de Jaén con la que abrimos este trabajo. Finalmente, el «staff» musical se completaba con diez clérigos sacerdotes, seguramente instruidos en canto llano, con responsabilidad de decir misa y asistir a la Salve y Maitines; y dos capellanes por oposición dedicados en exclusiva a la Santa Capilla (se prohíbe que sirvan otros beneficios) que debían estar versados al menos en gregoriano y examinarse por un libro de canto que había en la propia capilla ${ }^{35}$. Si entre los capellanes opositores hubiese alguno versado en polifonía, se le daba prioridad en igualdad de condiciones ${ }^{36}$. Ello indica que los capellanes eran los responsables directos del canto llano, de ahí que en los estatutos no se haga referencia al sochantre, figura que no se introduce en la Santa Capilla hasta bien entrado el siglo XVII.

La Tabla 1 recoge las asistencias obligadas de los cantores establecidas en los estatutos, que aluden expresamente a que las misas de los domingos y fiestas de guardar debían hacerse "conformes al estilo y costumbre de la Iglesia Cate- dral de la ciudad de Jaén, salvo en todas las fiestas de Nuestra Señora y todas las otras que solemnizare la Santa Capilla, que la ha de decir cantada en ella" ${ }^{37}$, es decir, en polifonía. Este énfasis en la solemnidad de las fiestas de la Virgen está en consonancia con la advocación mariana de la cofradía. Como parte de sus obligaciones, los cantores debían participar, bajo pena de multa, en la Misa y las Vísperas todos los domingos y fiestas de guardar, entre ellas una serie de celebraciones a las que también asistía la Universidad de Priores y Curas Párrocos (tratado III, capítulo VII). Los cantores asimismo debían asistir a los Maitines de otras celebraciones, recibiendo por ello un salario adicional (tratado III, capítulo V), así como a algunas procesiones que permitían proyectar la magnificencia de la cofradía en su marco urbano. Más adelante (secciones 4 y 5) proponemos algunas hipótesis en relación al repertorio polifónico que pudo utilizarse en estas celebraciones. De todo ello podemos concluir que la presencia de la música polifónica en la Santa Capilla era constante, lo que permitió a los fieles de San Andrés escuchar polifonía de manera cotidiana, cosa que no ocurría ni mucho menos en todas las parroquias; en este aspecto, así como en su particular modelo de financiación a través de la obra pía de un particular (y no de los fondos parroquiales) radica la principal singularidad de la Santa Capilla en términos institucionales ${ }^{38}$.

Tabla 1. Asistencias de la capilla de cantores a festividades de la Santa Capilla de San Andrés

(Libro de los Estatutos, 101-108).

\begin{tabular}{|c|l|}
\hline Todos los Lunes & $\begin{array}{l}\text { Misa de alba de los Ángeles. } \\
\text { Conmemoración de los difuntos: primer responso de Vísperas en “canto de órgano". }\end{array}$ \\
\hline Todos los Jueves & Misa del Corpus Christi, Vísperas, Completas y Salve. \\
\hline Todos los Sábados & $\begin{array}{l}\text { Misa de Nuestra Señora y Salve "con mucha solemnidad de canto de órgano". } \\
\text { Los sábados de Resurrección en lugar de la Salve se canta la antífona Regina caeli } \\
\text { y las otras antífonas que ocurrieren, "con toda la solemnidad que ser pueda". }\end{array}$ \\
\hline Todos los Domingos y días de fiesta \\
de guardar & Misa mayor. \\
\hline Fiestas "con los cantores y con la & $\begin{array}{l}\text { San Sebastián (20 enero), Nombre del Señor (7 febrero), Ángel custodio (16 febrero), } \\
\text { San Gregorio (12 marzo), San José (19 marzo), Corona Domini (4 mayo), Santa } \\
\text { Potenciana (19 mayo), Corpus Christi y su octava, diez fiestas de Nuestra Señora } \\
\text { [Purificación, 2 febrero; Anunciación, 25 marzo; Transfixión; Visitación (2 julio); } \\
\text { Virgen de las Nieves (5 agosto); Asunción (15 agosto); Natividad (8 septiembre); } \\
\text { Presentación (21 noviembre); Inmaculada (8 diciembre); la O (18 diciembre)]. }\end{array}$ \\
\hline
\end{tabular}

35 Libros de los Estatutos, 42-44, 46 y 104.

36 Libros de los Estatutos, 46.
37 Libros de los Estatutos, 65.

38 A diferencia de lo que ocurría en catedrales y colegiatas, donde la presencia de capillas de música era imprescindible, las parroquias tendían a circunscribir su actividad musical al órgano y al canto llano, si bien no faltan ejemplos puntuales de capillas polifónicas parroquiales, casi siempre de modestas dimensiones. Véanse algunos ejemplos en PÉREZ MANCILLA, Victoriano, 2013: 47-80. 


\begin{tabular}{|c|c|}
\hline Maitines de diversas festividades ${ }^{39}$ & $\begin{array}{l}\text { De enero a diciembre: San Esteban, San Juan Apóstol y Evangelista, Circuncisión, } \\
\text { Epifanía, San Sebastián, San Ildefonso, Santa María de la Paz, Conversión de } \\
\text { Pablo, Purificación de la Virgen (Candelaria), Nombre del Señor, Ángel custodio, } \\
\text { San Gregorio, San Gabriel, San José y Anunciación de la Virgen, segundo día } \\
\text { de Pascua de Resurrección, San Marcos, Invención de la Cruz, Corona Domini, } \\
\text { Santa Potencia, Ascensión del Señor, segundo día de Pascua del Espíritu Santo, } \\
\text { Trinidad, Corpus y su octava, San Juan Bautista, Visitación de María, María } \\
\text { Magdalena, Santiago, Santa Ana, Santa Marta, Víncula de San Pedro, Santa María } \\
\text { de las Nieves, San Lorenzo, Asunción y Natividad de la Virgen, Exaltación de la } \\
\text { Cruz, San Miguel, San Jerónimo, San Francisco, San Lucas, Todos los Santos, } \\
\text { Presentación de la Virgen, Santa Catalina, San Andrés, Inmaculada, Navidad, } \\
\text { Santa Lucía, Santa María de la O. }\end{array}$ \\
\hline Procesiones de la cofradía & $\begin{array}{l}\text { Corpus Christi y su octava (procesión por la colación y parroquia). } \\
\text { Procesión el Jueves Santo tras las Tinieblas (con parada en la catedral y otras } \\
\text { parroquias principales). }\end{array}$ \\
\hline Aniversario por los difuntos & $\begin{array}{l}\text { Aniversario por los difuntos el día siguiente a la Inmaculada (con Vísperas el } \\
\text { mismo día de la Inmaculada y al día siguiente Misa de réquiem, con responso, } \\
\text { cantada en la capilla "con mucha solemnidad"). }\end{array}$ \\
\hline
\end{tabular}

Una de las obligaciones que destacan los estatutos es la relativa a la docencia de la música que estaría a cargo principalmente del maestro de capilla, quien debía instruir a los capellanes, mozos de coro y demás ministros tanto en el canto llano como el de órgano o polifónico. Para lo primero sería ayudado por los propios cantores, dando éstos las clases una o dos veces al día "repartiendo entre ellos el tiempo y trabajo por semanas o por meses o como a ellos mejor visto fuere y se concertaren por manera que cada día ordinariamente den lección a los que la quieran oír, según dicho es, sin les llevar cosa alguna. Pero a los de fuera de la Capilla bien podrán llevar lo que les pareciere" ${ }^{40}$. Este condicionamiento de la percepción de una gratificación a cambio de la enseñanza musical, lejos de limitar el proceso en sí, suponía una apertura hacia las personas no pertenecientes a la propia iglesia, en una época en que este tipo de educación organizada estaba muy restringida, al servicio de la religión y al alcance de unos pocos.

En síntesis, la capilla de música de la Santa Capilla estaba compuesta por un grupo de cuatro cantores, que crecería con el tiempo hasta los ocho de $1590^{41}$, coincidiendo con periodos de mayor prosperidad, a los que había que agre-

$39 \mathrm{Su}$ asistencia comportaba un salario adicional de tres maravedís para los cantores, si no eran sacerdotes.

40 Libros de los Estatutos, 58. Véase JIMÉNEZ CAVALLÉ, Pedro, 1988: 138.

41 Se trataba de Alonso de Huéscar, Miguel de Alvarado, Pedro de Salas, Domingo de la Pinilla, Juan de los Santos, Pedro Prieto y un cantor de nombre no especificado, además del maestro (AHSCSAJ, leg. 12, "Cuentas Hacienda 1590-1604", Libro de cuentas 1590-1604, s.f., descargo de 1590). Ocho cantores hubo también en 1544; véase JIMÉNEZ CAVALLÉ, Pedro, 1987: 15. gar los mozos de coro o seises, desde los cuatro o seis que requieren los estatutos y que figuran en 1536 hasta los diez de $1573^{42}$, todos ellos dirigidos por el maestro que, además, tenía la obligación de componer música religiosa, tanto en latín, como en castellano. Este modesto conjunto vocal, reunido en torno a un atril o facistol, era apto para la interpretación de la música polifónica de la época y contaría en algunos momentos con la ayuda del organista, quien tenía cada día dos horas de ejercicio: una en la "música" (con la capilla) y otra en el órgano, como así se especifica en 1632 en relación al nombramiento del nuevo organista, Juan de la Peña ${ }^{43}$.

No hay mención alguna en los estatutos a la participación de los instrumentos, a excepción del órgano. Sin embargo, consta desde temprano la colaboración de instrumentistas a propósito de acontecimientos importantes en la historia de la cofradía. Así, en 1528, con ocasión de la concesión de ciertas indulgencias a favor de la Santa Capilla, se abonaron un ducado a las trompetas y tres reales a los pregoneros ${ }^{44}$. Dado que el pregonero solía ser un oficial público asalariado

42 Los nombres de los seis mozos activos en 1536 eran Juan de Almagro, Bartolomé Murillo, Luis de Cambil, Juan de Galta (seguramente hijo del cantor Francisco de Galta), Miguel Álvarez y Andrés de Arjona; véase AHSCSAJ, leg. 10, “Cuentas Hacienda 1531-1543”, Libro de cuentas 1531-1543, f. 161v, descargo de 1536; y leg. 11, "Cuentas Hacienda 1551-1619", Libro de cuentas 1561-1578, s.f., descargo de 1573.

43 AHSCSAJ, Actas Capitulares (AC), libro 6, 18-VII-1632, f. 43r. Peña fue el ganador de las oposiciones convocadas tras la muerte de Gaspar de Pancorbo y estuvo en activo hasta su muerte en 1671.

44 AHSCSA, leg. 9, "Cuentas Hacienda 1523-1555", Libro de cuentas 1523-1530, s.f., descargo de 1528. 
por el ayuntamiento, es probable que las trompetas también lo fueran y que, aunque no se cite, fuesen acompañadas de atabales para llamar la atención de los ciudadanos y dar una dimensión sonora y representativa al evento. Es de suponer que, al igual que ocurrió en otras muchas parroquias, los ministriles pasasen al interior de la iglesia y participasen desde temprano en la solemnización de los oficios, ya fuera reforzando o sustituyendo a las voces, si bien no hemos podido precisar una fecha exacta. En abril de 1605, el gobierno de la cofradía ordena taxativamente que "se traigan ministriles para el servicio de la dicha Santa Capilla por ser así cosa muy decente y de mucho ornato y de aumento del culto divino", encomendando el asunto al Gobernador ${ }^{45}$. Un acuerdo posterior, del 15 de octubre de 1606, da cuenta del "concierto salario" de 10.000 maravedís establecido con Francisco de Morales y tres ministriles más de Jaén (entre ellos el bajón Mateo de Torres) para su incorporación a la Santa Capil$\mathrm{la}^{46}$. Aunque la redacción de ambos acuerdos da a entender que la presencia de ministriles suponía toda una novedad y que en ese momento no parece que los hubiera y que había que traerlos, hemos localizado pagos a "chirimías" durante cuatro años consecutivos (1568-1571) por valor de treinta ducados u 11.250 maravedís ${ }^{47}$. Ello indica que, aunque la contratación de ministriles como miembros de plantilla se produjo en 1605, su presencia efectiva en San Andrés era anterior, si bien con carácter de invitados eventuales. Ciertamente a partir de esa fecha las noticias sobre instrumentistas se incrementan en las actas y, en paralelo, las quejas y amenazas del cabildo por sus continuas ausencias ${ }^{48}$.

Si bien no consta expresamente, es probable que los chirimías registrados en la Santa Capilla a finales de la década de 1560 solemnizando funciones litúrgicas fueran los de la catedral, quienes aprovechando el prestigio de la institución desplegaron una intensa actividad ceremonial en la ciudad, sujeta -al menos teóricamente- a la licencia del cabildo. Los ministriles están documentados en la catedral desde el primer libro de actas conservado, que se inicia en 1540. A las cornetas y chirimías asalariadas entonces se unió un sacabuche en 1541; en esa misma década se mencionan también las flautas. En 1573 se añadió el bajón (instrumento fundamental como apoyo del canto llano y la capilla vocal) y diez años después un segundo sacabuche ${ }^{49}$.

45 AHSCSAJ, $A C$, libro 4, f. 140r, 24-IV-1605.

46 AHSCSAJ, $A C$, libro 4, f. 169v, 15-X-1606.

47 AHSCSAJ, leg. 11, “Cuentas Hacienda 1561-1619”, Libro de cuentas 1561-1578, s.f., pagos reflejados en los descargos de 1569 , 1570,1571 y 1572 , relativos a los años inmediatamente anteriores. IV-1615.

48 AHSCSAJ, $A C$, libro 4, f. 189v, 21-X-1607; y f. 348v, 20-

49 AHDJ, $A C$, libro 2, f. 4v, 17-IX-1540; f. 46r, 22-VIII-1541;
Al igual que ocurría en otras ciudades, los ministriles de la catedral funcionaban como una agrupación independiente de los cantores, con su propio estatus social y jurídico, y con un régimen de trabajo y libros de música específicos, ofreciendo sus servicios a diversas instituciones y particulares. Así ocurrió en 1542, cuando los instrumentistas catedralicios obtienen licencia para ir a Úbeda, o en 1544 , cuando se autoriza su asistencia a la profesión de una monja en el monasterio de Santa Clara en la misma ciudad de Jaén, práctica que se repetiría en años sucesivos en los más variados eventos, tanto religiosos como civiles y tanto públicos como privados (corridas de toros, funerales, juegos de cañas, etc. $)^{50}$.

El creciente número de salidas al exterior, y los pingües beneficios que ellas reportaban a los ministriles catedralicios, los obligó a agruparse formando compañías y a regular ante notario su constitución y régimen de funcionamiento. Así, sabemos que en 1586 los ministriles Pablo Dueñas, Pedro Fernández, Cristóbal Zamorano, Gabriel Carrillo y Francisco de Torres establecieron una compañía estable para actuar fuera de la Catedral de Jaén, repartiendo el salario a partes iguales y comprometiéndose a no formar compañías con otros ministriles de la ciudad ${ }^{51}$. Estas compañías o "copias" de ministriles, a veces denominadas "extravagantes" y sin adscripción institucional en algunos casos, formaban redes socio-profesionales de gran importancia en las que la solidaridad, la exclusividad y la formación de aprendices y discípulos eran valores por todos respetados ${ }^{52}$.

Agrupaciones de ministriles como la formada en 1586 u otras análogas sirvieron para reforzar la ya de por sí estrecha relación entre los músicos catedralicios y los de la Santa Capilla. Sabemos, por ejemplo, que los músicos de la seo actuaban como jueces en las oposiciones a plazas de la misma índole en San Andrés, como ocurrió en 1543 al quedar vacante el puesto de maestro de capilla. En esta ocasión los opositores Luis de Vergara y Martín de la Fuente fueron examinados en contrapunto y canto de órgano por el racionero de la catedral Francisco de Molina y por el maestro de la misma, Antonio de Viana ${ }^{53}$. Incluso en algunos casos se producirían movimientos de una institución a otra de maestros de capilla -como veremos después-, mozos de coro, cantores y capellanes, lo que sin duda llevó aparejado un intercambio

f. 47v, 26-IX-1541; f. 74r, 16-III-1542; f. 136r, 14-VI-1544; libro 3, f. 189r, 17-VII-1573; y libro 9, f. 141v, 7-X-1583.

50 AHDJ, $A C$, libro 2, f. 74r, 16-III-1542; y f. 136r, 14-VI-1544.

Para otros ejemplos, véase JIMÉNEZ CAVALLÉ, Pedro, 1998.

51 LÓPEZ MOLINA, Manuel, 2001: 93-96.

52 BEJARANO PELLICER, Clara, 2013: 315-336.

53 AHSCSAJ, $A C$, libro 2, s.f., 6-VIII-1543. 
de prácticas y repertorios musicales ${ }^{54}$. Quizá debido a esta fluida relación pudo haber un acuerdo informal que permitiese actuar a los ministriles catedralicios en San Andrés sin una licencia reglada, y esa podría ser la razón por la cual no ha quedado rastro documental de esas participaciones. Pero la información de mayor relevancia que podemos aportar sobre la posible presencia de los ministriles catedralicios en la Santa Capilla lo tenemos en el hecho de que Francisco Carrillo, ministril chirimía de la iglesia mayor desde $1559^{55}$ e iniciador de una destacada saga de instrumentistas, era un valedor de la institución de San Andrés al aportar 80.000 maravedís de un censo perpetuo de su propiedad ${ }^{56}$. Esta noticia evidencia cómo los músicos catedralicios se proyectaron en la trama urbana y desarrollaron una intensiva vida social y devocional fuera de sus instituciones de referencia.

En relación a las fuentes de financiación de los salarios de cantores e instrumentistas al servicio de la Santa Capilla, es necesario mencionar la importancia que adquirieron los sucesivos patronatos que se fueron anexando a la obra pía fundacional de Gutierre González. Estos padrinazgos alcanzaron el número de setenta y uno y la aplicación de sus rentas -derivadas sobre todo de propiedades rústicas-a favor de los fines de la cofradía hizo de la Santa Capilla la institución económica más poderosa de Jaén tras el cabildo catedral. Algunas de estas prósperas fundaciones tuvieron implicaciones musicales directas, pues aumentaron el número de efectivos de la capilla musical, mejoraron las condiciones de los ya existentes y, en algún caso, pudieron llevar aparejada la composición de nuevos repertorios (tanto monódicos como polifónicos), incrementando de manera notable la actividad ceremonial de San Andrés, tal y como se ha documentado en otros lugares ${ }^{57}$. Una

54 A título de ejemplo, los cantores Alonso Molina, García de Arnedo, Francisco de Heredia y Alonso de Navarrete, junto con el maestro Diego Jiménez, activos en 1564-66 en la Santa Capilla, pasaron antes o después de ese momento por la catedral (leg. 11, "Cuentas Hacienda 1551-1619", Libro de cuentas 1561-1578, s.f., descargos de 1564 y 1566). Un capellán de San Andrés, Juan Pérez, fue contratado como contrabajo por la catedral en 1571 (AHDJ, $A C$, libro 5, f. 95r, 9-XI-1571). Siendo mozo de coro en la Santa Capilla, Pedro de Figueroa fue empleado por la catedral en 1604 (AHDJ, $A C$, libro 9, f. 232v, 17-XII-1604). A la inversa, Francisco de Mesa, mozo de coro en la catedral desde 1600, fue fichado como contralto en San Andrés, donde se le concedió un aumento de salario en 1609 (AHDJ, $A C$, libro 12, ff. $133 \mathrm{v}$ 134r, 11-XII-1600; AHSCSAJ, AC, libro 4, f. 232v, 23-VIII-1609).

55 AHDJ, $A C$, libro 3, f. 238r, 2-VI-1559.

56 AHSCSAJ, leg. 11, "Cuentas Hacienda 1551-1619", Libro de cuentas 1561-1578, s.f., descargo de 1575, relativo al año anterior; y leg. 12, "Cuentas Hacienda 1590-1604", Libro de cuentas 1590-1604, s.f., descargo de 12-X-1602. Carrillo tuvo un hijo también llamado Francisco que fue organista de la Catedral de Jaén; véase JIMÉNEZ CAVALLÉ, Pedro, 1996: 185-195.

$57 \mathrm{La}$ importancia musical de estas dotaciones privadas fue subrayada hace años por HAGG, Barbara, 1992: 60-68. Para un caso de de las fundaciones más significativas de esta primera etapa fue la de Luis de Aguilar, hijo del notario Miguel de Aguilar, miembro de la parentela de la Santa Capilla desde 1553 y secretario del cabildo desde finales del siglo XVI ${ }^{58}$. En 1606 Aguilar instauró un patronato y una de sus cláusulas indicaba que el dinero sobrante de las rentas de su hacienda debía dedicarse (por este orden) a comprar más fincas, a aumentar "los ministriles y la música de cantores" y a los capellanes. Tras analizar la última voluntad del donante, la situación de riesgo en que se encontraban los ministriles "por ser tan poco" su salario y "el ornato que con ella [la música de los ministriles] tiene el culto divino y lo que importa para la celebración de las fiestas", el cabildo acordó en 1612 que 10.000 de los 44.000 maravedís excedentes del patronato ese año sirviesen para aumentar el salario de los dos ministriles ya en plantilla, Mateo de Torres y Alonso de la Cueva, y dar una renta digna a los dos que venían actuando hasta entonces «gratis et amore», Juan de Vilches y Alonso de la Calle ${ }^{59}$.

Finalmente, durante esta centuria la capilla de cantores de la Santa Capilla se proyectó también fuera de su ámbito natural y actuó, en algunas ocasiones, fuera de su iglesia en determinadas fiestas, como las celebradas en 1573 en honor de Santa Catalina, a requerimiento del cabildo municipal ${ }^{60}$. La práctica parece que era habitual, pues informado el cabildo en 1611 de que maestro y cantores iban a cantar a otras iglesias y descuidaban los oficios de la Santa Capilla, les amenazó con multarles ${ }^{61}$. Ello comporta que, a veces, los cantores de la institución, lejos de colaborar con los de la catedral pudieron hacerles la competencia. Esto mismo se aplica al terreno de los instrumentistas, como lo prueba un protocolo notarial de 1619; en esa época, con la capilla de ministriles de San Andrés perfectamente estructurada, los instrumentistas de la catedral se vieron obligados a establecer un contrato con los de la Santa Capilla para evitar favoritismos y competencia desleal entre los músicos de ambos colectivos de cara a los servicios externos por los que competían ${ }^{62}$.

estudio español sobre aniversarios particulares de difuntos, véase RUIZ JIMÉNEZ, Juan, 2014: 53-88.

58 LÓPEZ ARANDIA, María Amparo, 2007: 711.

59 AHSCSAJ, $A C$, libro 4, ff. 298r-v, 7-XII-1612. A Mateo de Torres le aumentaron 2.000 maravedís (que se añadieron a los 5.000 que ya cobraba de la Santa Capilla); a Alonso de la Cueva le añadieron 1.000 (sobre los 3.000 que ya tenía); y a Juan de Vilches y Alonso de la Calle les dieron 3.500 maravedís a cada uno "por no tener como no tienen salario ninguno de la Santa Capilla".

60 Archivo Histórico Municipal de Jaén, leg. 185, "Libro de cuentas de propios de la ciudad de Jaen", 22-XII-1573.

61 AHSCSAJ, $A C$, libro 4, f. 262r, 13-III-1611.

62 LÓPEZ MOLINA, Manuel, 1997: 345-351. A lo largo del siglo XVII la capilla de ministriles de San Andrés fue requerida en varios entierros; véase LÓPEZ MOLINA, Manuel, 1998: 57-61. 
En resumen, los aspectos comentados a propósito del funcionamiento del colectivo musical de la Santa Capilla son los típicos de las agrupaciones religiosas y sugieren que, en lo que a número de efectivos musicales y rentas se refiere, no estamos ante un centro situado en la cúspide del sistema eclesiástico castellano. Sin embargo, y al igual que otras parroquias y centros musicales "menores", la Santa Capilla se aproximó a la cima gracias a sus intensas relaciones con la seo jiennense y a un pequeño pero solvente y continuado grupo de cantores profesionales, cuya cantidad y diversidad de actividades musicales no debe subestimarse. Tamaño y riqueza (dos de las categorías favoritas usadas por los musicólogos a la hora de clasificar estas instituciones) no son incompatibles con la funcionalidad y el refinamiento musical ${ }^{63}$.

\section{EL MAGISTERIO DE CAPILLA DURANTE EL SIGLO DE FUNDACIÓN}

De todos los músicos integrantes de la capilla, obviamente destacaban por su protagonismo los maestros en su triple condición de responsables de la enseñanza musical (algo de particular relevancia en la Santa Capilla, dados sus fines fundacionales), directores del conjunto vocal-instrumental y compositores de la música que solemnizaba los cultos de la cofradía, de acuerdo con su obligación. Esta triple función ya se recoge en la definición del "maestro de capilla" que ofrece Alonso de Covarrubias en su diccionario de la lengua castellana (1611): "El que gobierna el facistol y cantores, llevándoles el compás y volviendo a entrar en labor al que yerra, Latine Rithmicus, \& Phonascus. Ultra de esto los maestros de capilla componen su música de misas, motetes, \&c" ${ }^{64}$. Sin embargo, en los primeros maestros -que eran experimentados cantores- parece que primó más su labor como profesores de música y como directores de la capilla que como compositores ${ }^{65}$.

Aunque no se indica de manera expresa en los estatutos, la plaza de maestro se cubría por oposición a la que generalmente acudían como jueces los músicos de la catedral, operando los mecanismos habituales en otras poblaciones con varios centros musicales. Durante el siglo XVI, los edictos convocatorios, con los requisitos y condiciones de los aspirantes, se enviaban incluso a ciudades de prestigio fuera de la provincia (Granada, Sevilla, Málaga); con el paso del tiempo, y dado el escaso atractivo que las plazas suscitaban, se limitó

63 BURGESS, Clive y WATHEY, Andrew, 2005: 85-87. 64 COVARRUBIAS, Sebastián de, 1611: ff. 97v-98r.

65 Sobre la labor del maestro de capilla como director, si bien en un contexto un poco posterior, véase GONZÁLEZ MARÍN, Luis Antonio, 2010: 81-117. su colocación en las iglesias de Jaén, Úbeda, Baeza y Andújar, donde había capillas musicales importantes y las plazas ofertadas podían suscitar el interés de los músicos ${ }^{66}$. El plazo establecido para la presentación de los opositores era de 30 días y los ejercicios de oposición para la elección de "persona benemérita" eran los acostumbrados en este tipo de pruebas ${ }^{67}$. Por tanto, aunque en el archivo de San Andrés no tenemos constancia de la conservación de ninguna obra polifónica, incluido el siglo en el que nos estamos moviendo, es factible la aparición de música compuesta por alguno de los maestros que pasaron por esta institución, dado el constante y natural intercambio de músicos y repertorios producido entre centros religiosos del entorno. Algo que parece a primera vista poco probable, no resulta imposible, como después veremos.

La Tabla 2 ofrece cronológicamente los maestros de capilla que se sucedieron durante el siglo XVI, añadiendo cuatro nuevos nombres con respecto a la secuencia conocida hasta la fecha ${ }^{68}$. En la mayoría de los casos, observamos una presencia breve en el tiempo, lo que nos induce a pensar que la Santa Capilla, dentro de la red de instituciones eclesiásticas de la que formaba parte, funcionaba como centro de paso en el que jóvenes maestros desarrollaban su labor de manera provisional unos años mientras adquirían la necesaria experiencia profesional antes de dar el salto a un centro mejor dotado (y, por tanto, mejor retribuido) o de mayor prestigio $^{69}$. A ello pudo contribuir de manera determinante que los estatutos fijasen un techo salarial (100 ducados o 37.500 maravedís para el maestro de capilla y los cantores, y ocho ducados o 3.000 maravedís para el organista), animando a Gobernador y Consiliarios a tener cantores "por los menos salarios que puedan" y prohibiendo expresamente aumentos ("que en ningún momento del mundo se pueda crecer en poco ni en mucho") ${ }^{70}$. Como era de esperar, dicho mandato no se respetó de manera escrupulosa y hubo varios incrementos; durante la primera mitad del siglo el salario del maestro osciló entre los 6.000 y los 14.000 maravedís anuales, llegando a los excepcionales 38.744 maravedís de 1596. Sin embargo, la renta ofrecida por la Santa Capilla solía ser en líneas generales baja, asimilándose a la de catedrales peri-

66 JIMÉNEZ CAVALLÉ, Pedro, 1987: 14.

67 Ese fue el periodo fijado en los edictos convocatorios de 1605; véase AHSCSAJ, $A C$, libro 4, f. 151v, 20-I-1606. Para una síntesis sobre el contenido de las oposiciones a maestro de capilla en la España de la época, véase MARTÍNEZ GIL, Carlos, 2008: 141-151.

68 JIMÉNEZ CAVALLÉ, Pedro, 1987: 16; JIMÉNEZ CAVALLÉ, Pedro, 2007: 332. Pese a nuestros esfuerzos, persiste un vacío de unos quince años entre Diego Jiménez y Gil de Ávila.

69 Véase una variada casuística de la movilidad de los maestros de capilla sobre la base del factor económico en SUÁREZ-PAJARES, Javier, 2004: 149-197.

70 Libro de los Estatutos, 57. 
féricas y colegiatas ${ }^{71}$. A ello se añadía la circunstancia de que, a diferencia de lo que ocurría en la mayoría de las catedrales, donde el maestro de capilla era racionero (con las prerrogativas y honores que ello significaba), en la Santa Capilla no pasaba de un simple asalariado. Por tanto, la aspiración lógica de cualquier músico le llevaría a promocionar en búsqueda de las mejoras salariales y honoríficas que la Santa Capilla no ofrecía, de ahí la relativa inestabilidad en el cargo y la continua sucesión de maestros, una característica que también se aplica al caso de los organistas, de los que aquí no nos ocuparemos $^{72}$. Pero siempre había excepciones que obedecían a contingencias de diverso tipo, así como a factores personales. De este modo, sorprende que el maestro de capilla Antonio de Viana, procedente de la catedral, dejara su puesto allí, para «promocionan» al mismo cargo en la Santa Capilla; suponemos que debieron concurrir otras circunstancias que expliquen este funcionamiento teóricamente anómalo.

Tabla 2. Maestros de capilla durante el siglo XVI en la Santa Capilla de San Andrés de Jaén.

\begin{tabular}{|c|}
\hline Francisco Ribera (1528-1530) \\
Juan Moreno (1530-1531) \\
Lorenzo de Jara (1532) \\
Martín de Fuente (1533-1539) \\
Juan de Vilches (1539-1543) \\
Martín González (1543) \\
Martín de Fuente (1544-1545) \\
Antonio de Viana (1546-1547) \\
Diego Jiménez (1548-1553) \\
Gonzalo Cano (1553-1554) \\
Pedro de Baeza (1555-?) \\
Diego Jiménez (i1563?-desp. 1578) \\
-- \\
Gil de Ávila (1595-1597) \\
Cristóbal de Zafra (1597-1602)
\end{tabular}

A continuación, presentamos un esbozo biográfico de cada uno de los maestros de capilla que se sucedieron du-

71 SUÁREZ-PAJARES, Javier, 2004: 179-182.

72 Durante el siglo XVI se documenta la presencia de los organistas Diego de Palma (1523-1526), Pedro Rodríguez (1526-1534), Diego de Paredes (1534-1548), Juan de Aguilera (1548-1553), Baltasar de Paredes (1561-1578?) y Juan de Oñate (1590-1602). El salario pagado por la Santa Capilla (que se sumaba al dado por la parroquia) se mantuvo fijo (con algunas oscilaciones) desde mediados del siglo XVI en los 3.000 maravedís y 12 fanegas de trigo hasta que en 1632 se aumenta a los 5.000 maravedís y 24 fanegas de trigo. Véase JIMÉNEZ CAVALLÉ, Pedro, 1987: 15-16 y 18-19. rante el siglo XVI. La información que sobre ellos hemos localizado en el Archivo de San Andrés es limitada y fragmentaria debido a que de esa centuria sólo se han conservado dos libros de actas que cubren el periodo 1545-56 -libro 2- y 1598-1616 -libro 4-). Por su parte, los libros de fábrica, además de la dificultad paleográfica que presentan, no son del todo sistemáticos a la hora de reseñar el nombre del perceptor, lo que impide conocer multitud de detalles, ya no sólo de los maestros, sino del resto de músicos al servicio de la Santa Capilla (nombres, procedencia y destino, periodo de servicio, etc.). Pese a ello, han arrojado una valiosa información que pone de manifiesto la enorme movilidad de este colectivo.

\section{Francisco Ribera (1528-1530)}

La lenta consolidación del proyecto de Gutierre González hace suponer que durante los primeros años los servicios musicales en la Santa Capilla se limitarían al órgano y al canto llano, estando a cargo de los primeros músicos que aparecen en los libros de cuentas más antiguos, que se remontan a 1523: el organista Diego de Palma, los mozos Diego Gámiz, Jorge Lendínez y Tomás, y algún cantor adulto como Francisco de Galta, quien en 1528 recibió un pago por asistir a las Salves y más adelante (1536) figura con un salario de 8.000 maravedís ${ }^{73}$. Avanzada la década de 1520 , coincidiendo con la adquisición de los primeros libros de polifonía que han podido documentarse -como veremos en el siguiente apartado-, surge el primer maestro que conocemos, Francisco Ribera, quien estuvo activo entre el 28 diciembre de 1528 y, al menos, 1530. Gozó de un salario de 6.000 maravedís anuales como cantor y fue despedido el 30 de octubre de 1530, siendo sustituido por Juan Moreno. Con tal circunstancia se abonaron a Ribera 2.000 maravedís por el trabajo de cuatro meses ${ }^{74}$. Con Ribera (y su sucesor Juan Moreno) asistimos al prototipo de "maestro-cantor" encargado de poner en marcha la capilla, instaurar la enseñanza musical entre los mozos, organizar el repertorio y establecer un régimen de ensayos y dirección de las interpretaciones ("echando el compás"); muy poco después se consolidará el término maestro de capilla asociado ya a la composición.

Ignoramos si este Francisco Ribera se corresponde con el Francisco Ribera que aparece, a partir de 1543 y hasta

73 AHSCSA, leg. 9, "Cuentas Hacienda 1523-1555", Libro de cuentas 1523-1530, s.f., descargos de 1523,1525 y 1528 ; leg. 10 , "Cuentas Hacienda 1531-1543", Libro de cuentas 1531-1543, f. 162r, descargo de 1536.

74 AHSCSAJ, leg. 10, “Cuentas Hacienda 1531-1543”, Libro de cuentas 1531-1543, f. 17v, descargo de 1531. 
1555, como capellán encargado de corregir libros de canto y de la enseñanza de los mozos de coro en la catedral jiennen$\mathrm{se}^{75}$. Desconocemos igualmente si existió alguna relación de parentesco entre el Francisco Ribera maestro en San Andrés y Antonio Ribera, cantor de la capilla pontificia durante los últimos años del fundador González en Roma (desde antes de 1520 hasta, al menos, diciembre de 1528, pues ya no figura en los pagos papales de 1529), y autor de varias piezas en fuentes musicales del periodo de los Reyes Católicos ${ }^{76}$.

\section{Juan Moreno (1530-1531)}

Tras ser despedido Francisco Ribera se nombró en su lugar a Juan Moreno con un salario que duplicaba al de su predecesor: 12.000 maravedís. Moreno sirvió como maestro en la Santa Capilla desde el 30 de octubre de 1530 hasta el 15 de enero de 1531; por esos dos meses y medio recibió un salario de 2.500 maravedís $^{77}$. Probablemente este músico se corresponda con el cantor y capellán Juan Moreno que el 28 de marzo de 1536, tras la correspondiente bula papal, se convirtió en el primer racionero maestro de capilla de la catedral con un salario de 10.000 maravedís y dos cahíces de trigo; aunque el sueldo ofrecido en la seo era menor, llevaba aneja una ración. Moreno sirvió como maestro en la catedral hasta 1540 (cuando se nombró a Antonio de Viana), si bien siguió vinculado a esta institución hasta al menos $1542^{78}$.

\section{Lorenzo de Jara (1532)}

Desconocemos si alguien ocupó el magisterio de capilla entre Juan Moreno y Lorenzo de Jara, siguiente maestro que hemos podido documentar. Su salario anual quedó fijado en 10.000 maravedís, según consta por un pago que cubre desde el 1 de abril de 1532 hasta la Navidad de ese año. Jara servía en la Santa Capilla con anterioridad a su nombramiento, pues en 1531 recibió un pago por cuatro libros de canto de órgano, aunque no se precisa si eran de su autoría (Ilustración 1) ${ }^{79}$.

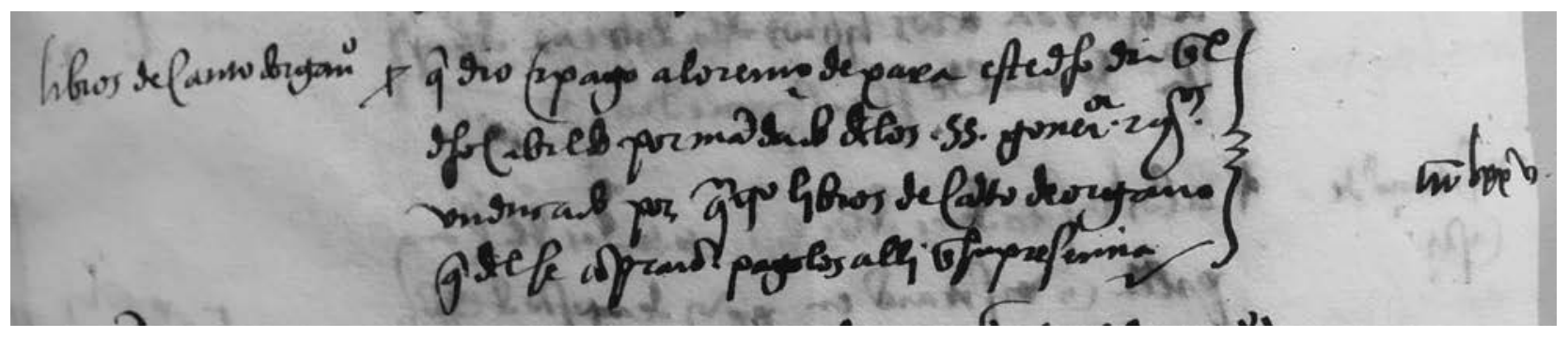

Ilustración 1. Lorenzo de Jara recibe un pago por cuatro libros de canto de órgano.

(Reproducida con autorización del Gobierno de la Santa Capilla).

75 AHDJ, $A C$, libro 2, ff. 118v-119r, 12-IX-1543; y libro 3, f. $149 \mathrm{v}, 16-\mathrm{II}-1555$.

76 KNIGHTON, Tess, 2002: 170-171. Otros destacados músicos del siglo XVI con ese apellido fueron Pedro (maestro de capilla en Xátiva, Orihuela y Murcia, donde se encuentra en 1535) y su hijo Bernardino (maestro de capilla en Lorca, Ávila, Toledo y Murcia, entre 1548-1580).

77 AHSCSAJ, leg. 10, “Cuentas Hacienda 1531-1543”, Libro de cuentas 1531-1543, f. 17v, descargo de 1531 .
78 AHDJ, leg. sin signatura, Informe sobre la ración de maestro de capilla 1536-1764, s.f.; AC, libro 2, f. 55r, 12-I-1542.

79 AHSCSAJ, leg. 10, “Cuentas Hacienda 1531-1543”, Libro de cuentas 1531-1543, f. 44v, descargo de 1531; y f. 61v, descargo de 1532. 


\section{Martín de Fuente (1533-1539 y 1544-1545)}

Martín de la Fuente sumó dos breves etapas al frente del magisterio de la Santa Capilla. La primera dio comienzo el 15 de noviembre de 1533 y se prolongó hasta 1539; debió de desempeñar el cargo provisionalmente o tras ser designado de manera directa, pues la oposición la ejercitó con posterioridad. Su salario se estableció en 14.000 maravedís, según consta por sendas libranzas de 1534 y $1536^{80}$. En el primer semestre de 1535 realizó un viaje de doce días a Sevilla, desconocemos si por asuntos musicales; por ello se le descontaron 311 maravedís de su salario ${ }^{81}$. En 1542 se le menciona como maestro de la parroquia de Santa María de Alcaudete ${ }^{82}$. Posteriormente en 1543, después de opositar al magisterio de San Andrés y ser examinado -como hemos mencionado- por el racionero Francisco de Molina y el maestro de capilla de la catedral Antonio de Viana, obtiene el puesto en propiedad y sirve, en una segunda etapa, entre el 20 de enero según las actas capitulares (25 según las libranzas) de 1544 y el 8 de agosto de 1545 , fecha en que se notifica su fallecimiento; durante este periodo fue advertido de la obligación de la enseñanza musical ${ }^{83}$. Curiosamente, por esta misma época, en 1544, aparecen unidos en un acuerdo del cabildo de la Catedral de Jaén los tres nombres citados anteriormente, Martín de la Fuente (aquí consta como racionero), Francisco de Molina y Antonio de Viana, al ordenar que Alonso Fernández Becerra, copista de libros, rehaga un libro de canto de órgano, de acuerdo con el gusto o "parecer" de los tres, concertándolo al precio de veinte reales cada cuaderno de ocho hojas ${ }^{84}$. La coincidencia de nombre y apellido nos lleva a buscar alguna relación de parentesco entre este Martín de Fuente y el músico homónimo que, según Baltasar Saldoni, fue discípulo de la Universidad de Salamanca y ejerció como maestro de capilla en la cercana Catedral de Córdoba entre 1505 y 1522, año en que falleció ${ }^{85}$.

80 En 1534 le pagaron 7.830 maravedís por servir desde el 15 de noviembre de 1533 hasta el 25 de junio de 1534; en 1536 cobró 14.000 maravedís; véase AHSCSAJ, leg. 10, "Cuentas Hacienda 1531-1543", Libro de cuentas 1531-1543, f. 82v, descargo de 1534; y f. 162r, descargo de 1536.

81 AHSCSAJ, leg. 10, “Cuentas Hacienda 1531-1543”, Libro de cuentas 1531-1543, f. 107r, descargo de 1535.

82 JIMÉNEZ CAVALLÉ, Pedro, 2007: 335.

83 AHSCSAJ, leg. 10, “Cuentas Hacienda 1531-1543”, Libro de cuentas 1531-1543, f. 249r, descargo de 1539; y $A C$, libro 2, s.f., 20-I$1544,20-\mathrm{VI}-1544$ y $30-\mathrm{VIII}-1545$.

84 AHDJ, $A C$, libro 2, f. 149r, 24-X-1544.

85 SALDONI, Baltasar, 1868-81: 169; NIETO CUMPLIDO, Manuel, 2004: 79-80. El nombre completo del maestro cordobés era Martín Rodríguez de la Fuente.

\section{Juan de Vilches (1539-1543)}

Poco sabemos de Juan de Vilches, quien figura cobrando salario de maestro en las libranzas de 1539 y dimitió, al marcharse a Granada, antes del 15 de julio de 1543 , fecha en que se convoca la plaza por su ausencia ${ }^{86}$. Aunque no hemos encontrado nada que relacione a este músico con iglesia alguna de Granada, como sería de esperar, sí aparece en la Catedral de Jaén, en junio de 1544, un Juan de Vilches, clérigo, que se recibe en dicha fecha como maestro cantor para la enseñanza de los mozos de coro, con el salario de 20.000 maravedís. Este oficio lo ejerció sólo unos pocos meses, pues en octubre del mismo año abandona tanto el servicio de la capellanía como la instrucción de los niños, de la que se ocuparía Antonio de Viana ${ }^{87}$. Hubo también en la misma catedral jiennense un racionero sochantre, cantor contrabajo, con el mismo nombre entre los años 1565 y $1577^{88}$. Ignoramos si el Juan Vilches de San Andrés tuvo algún parentesco con Bartolomé de Vílchez, maestro de capilla de la Catedral de Granada entre 1522 y $1523^{89}$. Cabe señalar que los Vilches conformaban un linaje jiennense muy vinculado a la Santa Capilla durante todo el siglo XVI, debido a que algunos de sus miembros formaron parte de la parentela del fundador González ${ }^{90}$. No sería extraño, por tanto, que el maestro de capilla Juan de Vilches perteneciese a dicha estirpe.

\section{Martín González (1543)}

A Juan de Vilches le sucedió Martín González, nombrado provisionalmente el 6 de agosto de 1543, tras los informes favorables sobre su habilidad por parte de los jueces Francisco de Molina y Antonio de Viana. El 7 de diciembre de 1543 se vuelve a anunciar la vacante del magisterio, por lo que entendemos que Martín González habría renunciado ya a su cargo o se vio obligado a dejarlo por otras circunstancias $^{91}$.

86 AHSCSAJ, leg. 10, "Cuentas Hacienda 1531-1543", Libro de cuentas 1531-1543, f. 249r, descargo de 1539; y $A C$, libro 2, s.f., 15 -VII-1543.

87 AHDJ, $A C$, libro 2, f. 136r, 14-VI-1544; y ff. 146v-147r, 3-X1544.

88 AHDJ, $A C$, libro 3, f. 345v, 1-X-1565; y libro 7, ff. 46v-47r, 7-VI-1577.

89 LÓPEZ-CALO, José, 1963: vol. 1, 151.

90 LÓPEZ ARANDIA, María Amparo, 2007: 800-804.

91 AHSCSAJ, $A C$, libro 2, s.f., 6-VIII-1543 y 7-XII-1543. 


\section{Antonio de Viana (1546-1547) y su hijo Juan Navarro}

Antonio de Viana fue maestro de capilla de la catedral jiennense desde 1540, al menos, hasta 1545 . Aunque no conocemos su lugar de nacimiento, el hecho de que, el 25 de junio de 1544 se le concediera una licencia de 40 días para ir a Barcelona nos hace sospechar que su origen no estuviera lejos de la Ciudad Condal ${ }^{92}$. El 11 del diciembre de 1545 se da cuenta de que Antonio de Viana se encuentra de maestro en la Santa Capilla ${ }^{93}$. Antes, el 25 de febrero del mismo año, se informa de que no enseña a los mozos de coro de la catedral, como es su obligación, por lo que debía pagar un real cada vez que faltase ${ }^{94}$. Estos mismos problemas los tendría en San Andrés en 1546 y $1547^{95}$, como, asimismo, su sucesor en la seo, Francisco Guerrero, quien tampoco pudo eludirlos. Durante su breve estancia en la Santa Capilla, Viana demostró un interés por renovar el repertorio, como se deduce de los libros copiados por Alonso Fernández Becerra en su época y de una petición expresa por parte del maestro en este sentido ${ }^{96}$. No cabe duda de que, cuando se trasladó de la catedral jiennense a San Andrés, echó de menos algunas obras que formaban parte del repertorio catedralicio. Su muerte se notificó el 24 de diciembre de 1547, por lo que debió fallecer pocos días antes ${ }^{97}$.
Entre los datos que aparecen en las actas sobre este maestro nos sorprende que, a principios de 1546, ofrezca al cabildo de la Santa Capilla a su hijo Juan Navarro para sustituir al organista titular Diego de Paredes si se ausentase, argumentando que "es de edad y tiene la habilidad que se requiere" (Ilustración 2) ${ }^{98}$. Ignoramos de quién se trata y de la relación real entre ellos, al no llevar, en este caso, su apellido Viana, pudiendo tratarse de un hijo putativo, sin descartar la posibilidad de que el padre utilizase un apellido toponímico, siguiendo una costumbre ampliamente extendida. Este Juan Navarro pudo seguir al servicio de San Andrés durante los siguientes años, ya que el cabildo aceptó la propuesta de Viana ("que se haga así como lo pide [el maestro] con condición [de] que cumpla lo que dice") y podría ser el Juan de Viana que en junio de 1549 se recibe como mozo de coro en la Catedral de Jaén y se asigna al entonces maestro, Francisco Guerrero ${ }^{99}$. De ser esto cierto, quedaría descartada la posibilidad de identificar a este Juan Navarro (o de Viana) con el homónimo Juan Navarro (ca. 1530-1580) que en septiembre de 1549 figura como cantor adulto en su pueblo natal, Marchena, al servicio del Duque de $\operatorname{Arcos}^{100}$, y que posteriormente aparece como tenor en la Catedral de Málaga y como maestro de capilla en diversas catedrales castellanas ${ }^{101}$. El testamento del Juan Navarro hispalense confirma que el nombre de su padre no era Antonio sino Rodrigo Navarro ${ }^{102}$.

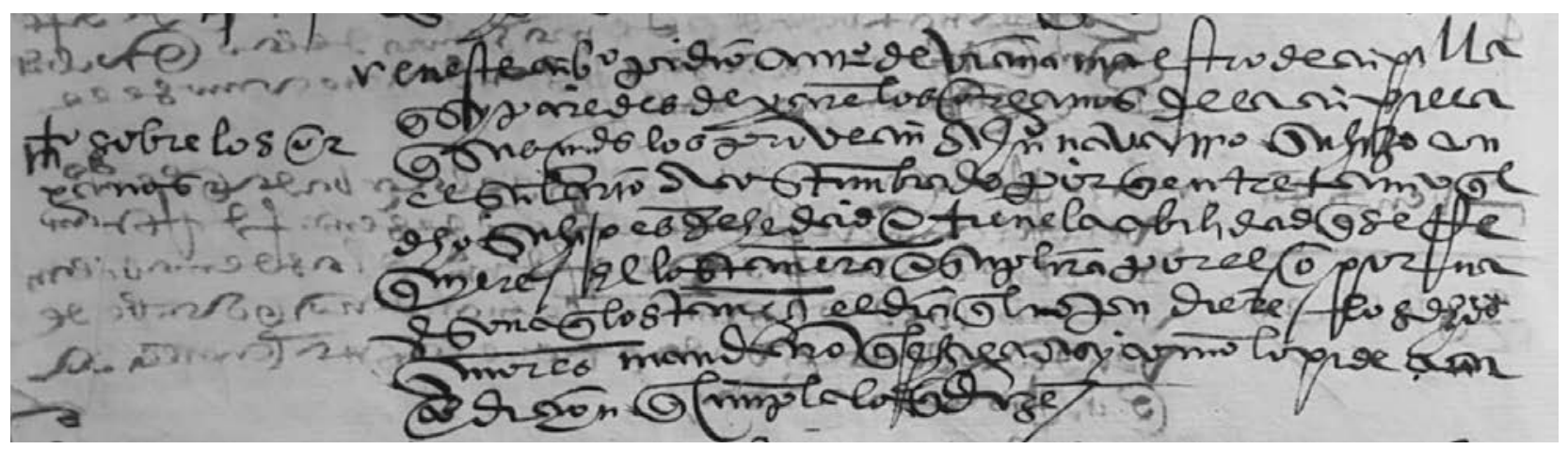

Ilustración 2. Ofrecimiento de Antonio de Viana de su hijo Juan Navarro como organista.

(Reproducida con autorización del Gobierno de la Santa Capilla).

92 AHDJ, $A C$, libro 2, f. 137r, 25-VI-1544. 93 AHDJ, $A C$, libro 3, f. 30v, 11-XII-1545. 94 AHDJ, $A C$, libro 3, f. 1v, 25-II-1545. 95 AHSCSAJ, $A C$, libro 2, s.f., 20-VI-1546. 96 AHSCSAJ, $A C$, libro 2, s.f., 21-VIII-1547. 97 AHSCSAJ, $A C$, libro 2, s.f., 24-XII-1547.
98 AHSCSAJ, $A C$, libro 2, s.f., 1-I-1546.

99 AHDJ, $A C$, libro 3, f. 22v, 6-IV-1549. Aunque es probable que Juan Navarro y Juan de Viana sean la misma persona, sorprende que en 1546 tenga la edad y habilidad requerida para tocar el órgano y tres años más tarde ingrese como mozo en la catedral.

100 ALVAREZ SOLAR-QUINTES, Nicolás, 1953: 35. Navarro figura en un recibo con un salario de 10.000 maravedís como cantor tenor en la capilla que entonces dirigía Cristóbal de Morales.

101 GÓMEZ PINTOR, María Asunción, 2000: 992; STEVENSON, Robert, 2001

102 GÓMEZ PINTOR, María Asunción, 1995: 27-46. 
Descartada la identificación entre el Juan Navarro, hijo de Antonio de Viana presentado en San Andrés, y Juan Navarro, cantor de Marchena, hay indicios que no podemos explorar en detalle aquí pero que invitan a especular con la posibilidad de que este último estuviese al servicio de la $\mathrm{Ca}$ tedral de Jaén. Sobre la base de dos actas capitulares de la Catedral de Málaga de 1553, la primera fechada el 12 de julio (en la que el sochantre propone la contratación de un "excelente tenor que canta en la Catedral de Jaén") y la segunda dos días después (con la contratación efectiva de Juan Navarro con un salario de 25.000 maravedís), Robert Stevenson propuso la identificación de este "excelente tenor" con el luego famoso Juan Navarro ${ }^{103}$. El vacío informativo en torno a este Juan Navarro durante los siete años posteriores (la siguiente noticia sobre él data de 1562, cuando se le recibe como maestro de capilla en la entonces Colegiata de Valladolid ${ }^{104}$ ) viene a coincidir con la estancia en Jaén de un tenor con el mismo apellido pero nombrado "Francisco" 105 . Este "Francisco" Navarro fue recibido en Jaén el 17 de agosto de 1555 , y dos meses después, el 23 de septiembre, le fue concedido un permiso de 20 días para ir por su hato a Málaga ${ }^{106}$, mientras que el 2 de octubre -coincidiendo con el permiso de "Francisco" en Málaga-, Juan Navarro presentó su dimisión al cabildo malagueño y pidió el abono de su mensualidad en concepto de paga "de ausencia definitiva" 107. Esta evidencia, unida a otras circunstancias (como las prolongadas ausencias de Juan Navarro en Valladolid y Ávila, coincidentes con pagos puntuales a "Francisco" en Jaén) y las dinámicas de movilidad de los músicos a mediados del siglo XVI, vendría a soportar la hipótesis de que el Juan Navarro de Málaga y el "Francisco" Navarro de Jaén pudieron ser una misma persona y que se trata de una simple confusión nominal. Pese a estas curiosas coincidencias, no podemos descartar la posibilidad de que se trate de personas distintas, dada la frecuencia de ese nombre y ese apellido en la España de la época.

103 STEVENSON, Robert, 1993: 276. En la edición española (1993) se cita de manera errónea el año 1554, que en la versión original inglesa (1961: 243) figura como 1553.

104 AIZPURÚA ZALACAÍN, Pedro, 1982: 340

105 En la Santa Capilla hemos documentado a dos tiples apellidados Navarro, Francisco y Salvador, asalariados en 1534-35 a razón de cinco ducados por año, cuya relación con Antonio de Viana y Juan Navarro ignoramos (AHSCSAJ, leg. 10, "Cuentas Hacienda 1531-1543", Libro de cuentas 1531-1543, ff. 106v-107r, descargo de 1535; y f. 162r, descargo de 1536). Desconocemos si el "Francisco" Navarro contratado en la catedral en 1555 es el mismo activo en San Andrés veinte años antes y si pudiera ser hermano de Salvador y Juan e hijo, por tanto, de Antonio de Viana.

106 AHDJ, $A C$, libro 3, 17-VIII-1555; y f. 170v, 23-IX-1555. 107 STEVENSON, Robert, 1993: 276.

\section{Diego Jiménez (1548-1553 y ¿1563?-1578p)}

Muy poca es la información que poseemos de Diego Jiménez, quien ejerció su magisterio en la Santa Capilla en dos periodos distintos, al igual que Martín de la Fuente. El primero de ellos se desarrolló desde 1548 hasta 1553, siendo muy posible que fuera la misma persona que, en 1541 , fue recibido como mozo de coro en la catedral jiennense, donde adquiriría su formación inicial ${ }^{108}$. En enero de 1549 se le pagan unos villancicos, seguramente compuestos para la Navidad anterior, que son los primeros del género que se pueden constatar en San Andrés y, en 1552, sería apercibido en al menos dos ocasiones, pidiendo perdón en 1553; el 16 de julio de este último año renuncia al cargo ${ }^{109}$. Seguramente deba identificarse a este músico con el clérigo que ejerció como maestro de capilla en la Catedral de Córdoba entre 1561 y $1562^{110}$. De ser esto cierto, Jiménez podría haber regresado a la Santa Capilla al año siguiente, pues se le documenta percibiendo un salario de 6.000 maravedís como maestro de capilla en la contabilidad de 1564; por un pago dos años posterior sabemos que adicionalmente ganaba otros 14.000 maravedís como capellán. La última noticia conocida de Jiménez data de 1578, cuando recibe una retribución de cuarenta y dos reales por un "breviario grande" 111.

\section{Gonzalo Cano (1553-1554)}

Gonzalo Cano, maestro de capilla durante los años 1553 y 1554, es otro de los ejemplos de movilidad entre las dos instituciones jiennenses; en este caso, pasó de cantor tiple de la catedral, donde fue recibido hacia el 8 de septiembre de 1545, a maestro de la Santa Capilla; en la iglesia mayor ingresó con el visto bueno del maestro Viana concediéndosele 2.000 maravedís para traer su casa, lo que implica que no era, o al menos no procedía entonces, de Jaén ${ }^{112}$. Fue nombrado maestro de la Santa Capilla el 6 de agosto de 1553 y despedido en octubre de 1554 por ciertas "irregularidades", que no se describen, después de haber

108 AHDJ, $A C$, libro 2, f. 45r, 19-VIII-1541.

109 AHSCSAJ, $A C$, libro 2 , s.f., 20-I-1549, 19-VI-1552, 11-XII$1552,19-$ II- 1553 y $16-\mathrm{VII}-1553$.

110 NIETO CUMPLIDO, Manuel, 2004: 87, da como fecha de cese en el magisterio el 28 de febrero de 1562, mientras que SALDONI, Baltasar, 1868-81: 179, indica -sin citar fuente alguna- que estuvo en el cargo hasta fin de junio de 1563 en que murió.

111 AHSCSA, leg. 11, "Cuentas Hacienda 1561-1619”, Libro de cuentas 1561-1578, s.f., descargos de 1564 y 1566; y leg. 1, "Hacienda 1534-1644", descargo de 1578.

112 AHDJ, $A C$, libro 2, f. 22r, 9-IX-1545. 
sido amonestado con anterioridad ${ }^{113}$. En febrero de 1554 lo encontramos como opositor al magisterio de capilla de la Catedral de Málaga junto al Juan Navarro hispalense, Luis de Cózar tío y su sobrino homónimo, Francisco Guerrero y Juan Dois"114. Se presentó entonces como "residente en Jaén" y obtuvo tan sólo un voto, siendo elegido Francisco Guerrero. Tras la renuncia de Guerrero en abril volvieron a realizarse oposiciones en junio y a ellas también concurrió Cano, quien tampoco resultó elegido; del nivel de estas oposiciones dan cuenta algunos de los aspirantes a la plaza, como Rodrigo de Ceballos o Juan Cepa, a la postre el vencedor.

\section{Pedro de Baeza (1555-?)}

Pedro de Baeza sucedió a Gonzalo Cano el 6 de enero de 1555 , sin que sepamos los años que ejerció el magisterio por falta de documentación ${ }^{115}$. En su época se renovó también el repertorio con las obras escritas por el referido Alonso Fernández, como ya mencionamos. Tras él debieron llegar otros maestros, entre ellos el citado Diego Jiménez y probablemente otros que no hemos podido identificar hasta que en 1595 encontramos a Gil de Ávila.

\section{Gil de Ávila (1595-1597)}

De todos los maestros del siglo XVI, acaso sea Gil de Ávila el que cuente con una historia profesional más rica y ejemplifique la tendencia contraria a la dinámica de funcionamiento habitual del magisterio de capilla en San Andrés, donde llegó tras haber adquirido un sólido bagaje en otros puestos. Quizá por ello se convirtió en el maestro de capilla con un salario más elevado durante los tres años en que estuvo al servicio de la Santa Capilla: 31.430 maravedís en $1595,38.744$ en 1596 y 24.538 por los servicios prestados hasta el 16 de febrero de $1597^{116}$. De procedencia desconocida, en un principio se pensó que este compositor, de quien se conservan dos juegos de ver- sos instrumentales en el libro de polifonía 19 de la $\mathrm{Ca}-$ tedral de Puebla (México) [MEX: Pc 19], podía ser -por tal circunstancia- un compositor posiblemente colonial ${ }^{117}$. Aunque ignoramos si como tantos otros colegas viajó al Nuevo Mundo, podemos afirmar que la mayor parte de su trayectoria profesional la desarrolló en la Península Ibérica. Hasta donde sabemos, los versos para ministriles conservados en la catedral angelopolitana son las únicas obras conocidas de Ávila y por ello ofrecemos su transcripción musical.

Gil de Ávila fue recibido, primeramente, en la Colegiata de Antequera como maestro de capilla el 21 de enero de 1574; allí fue multado en varias ocasiones por realizar funciones musicales fuera de la iglesia con los cantores. Tras una prolongada ausencia, dieron por vacante el magisterio y mandaron poner edictos convocatorios en 1582 , si bien Ávila (que parece que se encontraba entonces instalado en Úbeda), aceptó la nueva oferta del cabildo antequerano y fue nombrado maestro por el obispo Francisco Pacheco con las protestas de algunos capitulares. La peste de 1583 obligó a ausentarse de la ciudad a los miembros del capítulo de Antequera que, en 1584, volvieron a convocar nuevas oposiciones, proveyéndose el magisterio en Pedro Bermúdez ${ }^{118}$. No murió Ávila en esa epidemia, como supuso Andrés Llordén, sino que su historia continuó. En 1583 aparece como maestro de capilla del Hospital de Santiago de Úbeda, cargo que seguía ocupando en $1592^{119}$. Previsiblemente se mantuvo en ese puesto hasta que en 1595 se localiza en la Santa Capilla de Jaén sin que sepamos si medió oposición y si contó con la presencia en el jurado del salmantino Francisco Ruiz de Espinosa, maestro de capilla de la seo jiennense. Quizás la cercanía de la catedral supuso un especial atractivo para él en esos años en que la capilla de música disfrutó de un gran esplendor en manos del citado maestro ${ }^{120}$. Entre los pagos registrados durante ese periodo consta una libranza por importe de 1.938 maravedís a un mozo de coro de idéntico nombre que podría ser hijo del compositor, extremo que no hemos podido confirmar (Ilustración 3) ${ }^{121}$.
113 AHSCSAJ, $A C$, libro 2, s.f., 6-VIII-1553 y 28-X-1554. 114 LLORDÉN, Andrés, 1961: 117-119.

115 AHSCSAJ, $A C$, libro 2, s.f., 6-I-1555.

116 AHSCSAJ, leg. 12, “Cuentas Hacienda 1590-1604”, Libro de cuentas 1590-1604, s.f., descargos de 1595, 1596 y 1597.
117 STANFORD, Thomas y SPIESS, Lincoln, 1969: 48.

118 LLORDÉN, Andrés, 1977: 115-165.

119 MARÍN LÓPEZ, Miguel Ángel, 2002: 148; JIMÉNEZ CAVALLÉ, Pedro, 2007: 334.

120 JIMÉNEZ CAVALLÉ, Pedro, 1983: 9-22.

121 AHSCSAJ, leg. 12, “Cuentas Hacienda 1590-1604”, Libro de cuentas 1590-1604, s.f., descargo de 1595. 


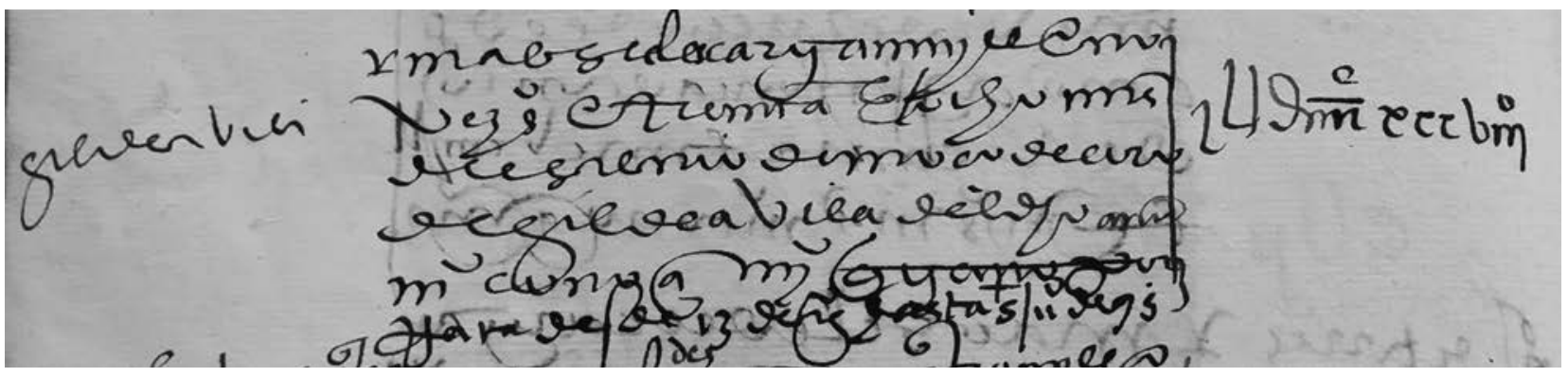

Ilustración 3. Pago al mozo de coro Gil de Ávila.

(Reproducida con autorización del Gobierno de la Santa Capilla).

El 10 de enero de 1597, tras ganar la correspondiente oposición (cuyos edictos convocatorios se enviaron a Granada, Córdoba, Jaén, Úbeda y Baeza), Ávila es nombrado maestro de seises de la Catedral de Sevilla por el tiempo que viviera el maestro Francisco Guerrero. Sin embargo, y tras solicitar un adelanto de su salario nada más llegar, Ávila renunció al cargo a los ocho meses y en su lugar fue nombrado Juan Baca. Se trata de la última noticia localizada de este itinerante músico ${ }^{122}$.

\section{Cristóbal de Zafra (1597-1602)}

Los libros de fábrica nos informan de que el sucesor de Gil de Ávila fue Cristóbal de Zafra, maestro de capilla en San Andrés entre 1597 y 1602, y que su salario quedó fijado en 26.000 maravedís, si bien tuvo que reclamarlo a finales de $1598^{123}$. Probablemente, este Cristóbal de Zafra sería el mismo que sirvió en la catedral en 1607 y 1608 como organista ${ }^{124}$ y que ejercería este oficio en la iglesia de San Ildefonso de Jaén a partir de $1614^{125}$. Es muy posible que su nombre se corresponda con un mozo de coro de la catedral que aparece en $1584^{126}$, y que pertenezca a la fami-

122 GONZÁLEZ BARRIONUEVO, Herminio, 2000: 213. De manera coincidente a la estancia en Sevilla del músico, un Gil González de Ávila, descendiente de otro Gil González de Ávila o Dávila (14801526), uno de los primeros conquistadores de las actuales Costa Rica y Nicaragua, solicitó un permiso para pasar a Nueva España con dos criados el 24 de diciembre de 1596; véase Archivo General de Indias, Indiferente, 2069, N.5, 24-XII-1596, licencia concedida el 17-I-1597. Un tercer González de Ávila (ca. 1570-1658) fue cronista de Felipe IV. 123 AHSCSAJ, $A C$, libro 4, f. 3r, 22-XII-1598; y leg. 12, "Cuentas Hacienda 1590-1604”, Libro de cuentas 1590-1604, s.f., descargo de 1598.

124 AHDJ, $A C$, libro 9, f. 335v, 8-VIII-1607; y f. 344v, 15-X1607.

125 JIMÉNEZ CAVALLÉ, Pedro, 1991: 94.

126 AHDJ, $A C$, libro 9, f. 196r, 28-VII-1584. lia de los Zafra, una saga de organistas que incluyó, entre otros, a Pedro de Zafra, organista de la catedral jiennense desde 1594, y a Fernando de Zafra, de la Capilla Real de Granada $^{127}$. Se trata de otro ejemplo más de la importancia de los vínculos familiares en la transmisión del oficio musical. Cristóbal de Zafra fue sustituido en 1602 por Cristóbal Suárez, quien se mantuvo en el cargo hasta 1611 , periodo en el que, como muchos de sus antecesores, intentó opositar a otras prebendas (en este caso a la Colegiata de Antequera) para así mejorar la corta renta ofrecida por la Santa Capilla ${ }^{128}$.

\section{EL REPERTORIO POLIFÓNICO}

En su origen, el repertorio polifónico interpretado en la Santa Capilla de San Andrés debió estar formado por una mezcla de música local e internacional, donde obviamente no faltarían las obras en latín (en particular para la Misa y el servicio de Vísperas, según requiere el calendario litúrgico incluido en los estatutos), ni tampoco las piezas en romance compuestas por los maestros de la institución; más, muy posiblemente, las correspondientes a los músicos de la catedral. A ellos se añadirían los grandes nombres de la polifonía española de la época, así como algunos foráneos franco-flamencos o italianos de amplia difusión entre las capillas eclesiásticas hispanas. No podemos descartar que, siguiendo una práctica bien establecida entre los clérigos, el propio Gutierre González enviase alguna colección impresa, recién salida de las prensas romanas, o algunas obras manuscritas, como las ya apuntadas de Francisco de Peñalosa o algún otro cantor-compositor de la Cappella Si-

127 AHDJ, $A C$, libro 10, f. 449v, 20-VI-1594; LÓPEZ-CALO, José, 2005: acuerdos 123 y 127.

128 LLORDÉN, Andrés, 1977: 126. 
stina a los que debió conocer, utilizando redes comerciales o los múltiples contactos que mantenía en y desde Roma con las gentes de Jaén ${ }^{129}$. Pero en realidad no tenemos documentación al respecto que nos confirme el hecho bastante probable.

La pérdida del archivo de papeles de música y varios libros de actas, correspondientes a una gran parte de la centuria estudiada, impide que documentemos el repertorio interpretado en la Santa Capilla que, probablemente, sería un centro más activo como receptor que como creador de polifonía ${ }^{130}$. En la documentación contable consultada de los primeros años hay diversas noticias relacionadas con la adquisición y encuadernación de libros litúrgicos y de canto. Así, en 1524 se adquirió un misal "de papel bueno" y en 1526 se registran dos pagos al librero Antonio de Medina, uno por el pergamino y las encuadernaciones de "los libros de canto" y otro más general "por los libros de cantoría". Más adelante, en 1531, se registra la compra de un libro "de marca mayor de seis manos" con misas por seis reales ${ }^{131}$. A veces conocemos el nombre de la persona que actúa como mediador de la compra, casi siempre cantores de la propia capilla, como ocurrió ese mismo año de 1531: el cantor Garabatea recibió cuatro ducados y medio el 20 de agosto por "un libro de canto de órgano", mientras que a Lorenzo de Jara le pagaron cierta cantidad de dinero por "cuatro libros de canto de órgano", que probablemente serían libretes de $\operatorname{partes}^{132}$. Aunque las colecciones no se pueden identificar, se constata la importante presencia de la música en la Santa Capilla desde la década de 1520 .

129 LÓPEZ ARANDIA, María Amparo, 2007: 287-294 y 349-381, donde documenta el envío de varios libros manuscritos e impresos con el ideario que González quería implantar en su cofradía.

130 Para evitar la dispersión del patrimonio musical de la Santa Capilla se acordó, en 1693-94, colocar todos los papeles de música en un arca bajo doble llave; véase LÓPEZ ARANDIA, María Amparo, 1995: 151.

131 AHSCSA, leg. 9, "Cuentas Hacienda 1523-1555”, Libro de cuentas 1523-1530, f. 23r, descargo de 1524; s.f., descargo de 1526; leg. 10, "Cuentas Hacienda 1531-1543", Libro de cuentas 1531-1543, ff. $41 \mathrm{v}$, descargo de 1531 .

132 AHSCSAJ, leg. 10, “Cuentas Hacienda 1531-1543”, Libro de cuentas 1531-1543, ff. 16r y 44r, descargo de 1531.
No hemos localizado ningún inventario en los libros de visita consultados correspondientes a los siglos XVI y XVII que arroje información sobre los libros de polifonía, aunque sí sobre libros litúrgicos y de canto llano ${ }^{133}$. Un inventario muy posterior contiene alguna información adicional sobre libros de polifonía que todavía se conservaban en 1813 pero que, según anota una mano más tardía, desaparecieron después (Tabla 3 ). La vaguedad en la descripción no permite identificar la naturaleza manuscrita o impresa de los volúmenes polifónicos ni tampoco a los autores, aunque sí los principales géneros (misas, salmos y magníficats para Vísperas y los polifuncionales motetes), el formato de conservación (libretes de partes en el caso de los nos. 15 y 16; libros de facistol en los restantes) y la condición de "antiguo" de uno de ellos (no. 13) ${ }^{134}$. Señala igualmente la presencia de dieciséis "libros de coro de pergamino" (no. 9) que seguramente se correspondan con los libros de canto llano hoy conservados ${ }^{135}$. Otras noticias relativas a la adquisición, aderezo o encuadernación de los libros confirman que, al igual que ocurría en las catedrales, la Santa Capilla contó con una nutrida colección de libros de polifonía para cubrir sus necesidades litúrgicas ${ }^{136}$.

133 AHSCSAJ, legs. 1, 23, 24, 317 y 318. En el leg. 1, "Hacienda 1534-1644", se incluye las visitas de 1556 y 1582, en las que se referencia un misal grande nuevo, un pasionario viejo, un cuaderno viejo para la bendición de la pila, un breviario de media cámara, un misal grande del Nuevo Rezado y ocho libros dominicales y santorales.

134 AHSCSAJ, leg. 65, "Inventario de las alhajas, ropa y demás efectos de la iglesia y sacristía de la Santa Capilla de la Parroquial de San Andrés de esta ciudad practicado por el Sr. D. Mariano Pérez, consiliario, en virtud de la comisión que se le confirió por los señores del gobierno de ella en cabildo de 1 de marzo de 1813, por el secretario de la misma, que con distinción de alhajas y clases de que se compone y corre a cargo del sacristán de la citada Santa Capilla es como sigue", s.f. [ff. 16r-v].

135 En la Sala de Juntas hay diecisiete cantorales, todos manuscritos a excepción de uno impreso en 1868. Algunos libros llevan fecha y nombre del copista (Diego Melero, 1770; Juan de Santamaría, 1777; Juan de López y Fernández, 1790) en tanto que otros pudieran ser del siglo XVI; véase LÓPEZ ARANDIA, María Amparo, 1995: 152-158.

136 AHSCSAJ, $A C$, libro 6, f. 45r, 19-IX-1632, recoge una petición del entonces maestro, Manuel del Portillo, relativa a cómo "unos libros de canto tenía necesidad que se aderezasen de encuadernación". 
Tabla 3. Misales, breviarios y libros de música en la Santa Capilla de San Andrés en 1813.

Nota: los añadidos en otra mano (posterior) se indican en cursiva.

N 1 Dos misales de cámara entera forrados de damasco carmesí, eon sus fundas de badana

N 2 Siete misales de media cámara.

N 3 Tres cuadernos de misa de requiem, el uno forrado en pergamino.

N 4 Dos ídem de epístolas y evangelios.

N 5 Dos pasionarios.

N 6 Dos cuadernillos de rezos de santos nuevos y del Obispado [al margen: "no existen"]

N 7 Đos-Un manuales el uno nuevo con corchetas. No hay más de uno.

Tresdos breviarios, el uno inservible.

N 8 Un breviario de cámara entera. Fres breviarios de cámara el uno nuevo.

N 9 Quince [encima: “diez y seis"] libros de coro de pergamino. son diez y seis

N 10 Otro de canto [de] órgano ídem no existe

N 11 Otro para la procesión del Domingo de Ramos ídem no lo hay

$\mathrm{N} 12$ Un libro de papel de marca de salmos y magníficats. no existe.

N 13 Otro de canto de órgano antiguo. no existe

$\mathrm{N} 14$ Otro de cuatro tomos en cuarto de canto [fol. 16v] [de] órgano con motes [sic = motetes] y misas. no existe

$\mathrm{N} 15$ Juego de libros de canto [de] órgano, encuadernados en pergamino. no existe

N 16 Un breviario veneciano de marca nuevo.

N 17 Dos epistolarios nuevos, dorados con sobre forro de valdes [sic] carmesí. no existe

N 18 Un libro de facistol para la música, nuevo. no existe

Cuatro breviarios con sus fundas.

Como vemos, las referencias a los libros de música suelen ser genéricas y no precisan en ningún caso el repertorio que contenían los volúmenes ni tampoco los compositores representados. Una notable excepción en lo que respecta al asunto de las autorías lo constituye el pago realizado en 1534 al librero Antonio de Medina por la compra de un libro "de canto de órgano de las obras de Jusquino" (Ilustración $4)^{137}$. Aunque la referencia es demasiado vaga como para proponer una identificación fiable, es probable que dicho libro de facistol fuese un impreso (no se mandó copiar, sino que directamente se compró), siendo la hipótesis más factible el Liber Quindecim Missarum (Roma, Andrea Antico, $\left.1516^{1}\right)$, de inmensa popularidad en el ámbito ibérico, donde fue conocido como el "libro de las quince misas de Josquin", aunque incluía también obras de otros compositores. El volumen está presente en los inventarios de muchas bibliotecas españolas, tanto de particulares como de catedrales (entre ellas la de Jaén, según revela un inventario de 1548 al que más adelante nos referiremos), por lo que su presencia en la Santa Capilla no constituiría ninguna anomalía. Sea o no este libro de misas, la presencia de música del legendario Josquin des Prez en el Archivo de la Santa Capilla da cuenta del nivel alcanzando por su capilla de cantores y su conocimiento de un repertorio de renombre y difusión internacional sólo unos pocos años después de su publicación y de manera casi simultánea a su aparición en destacados centros eclesiásticos hispanos ${ }^{138}$.
137 AHSCSAJ, leg. 10, "Cuentas Hacienda 1531-1543”, Libro de cuentas 1531-1543, f. 114r, descargo de 1534.
138 Por mencionar dos de los casos más tempranos, en la Catedral de Granada se compró música de Josquin en 1529 y en la de Toledo en 1532, si bien consta que su música circuló en la Península de manera manuscrita desde principios de siglo; véase LÓPEZ-CALO, José, 1963: vol. 1, 125; y NOONE, Michael, 2007: 249. 


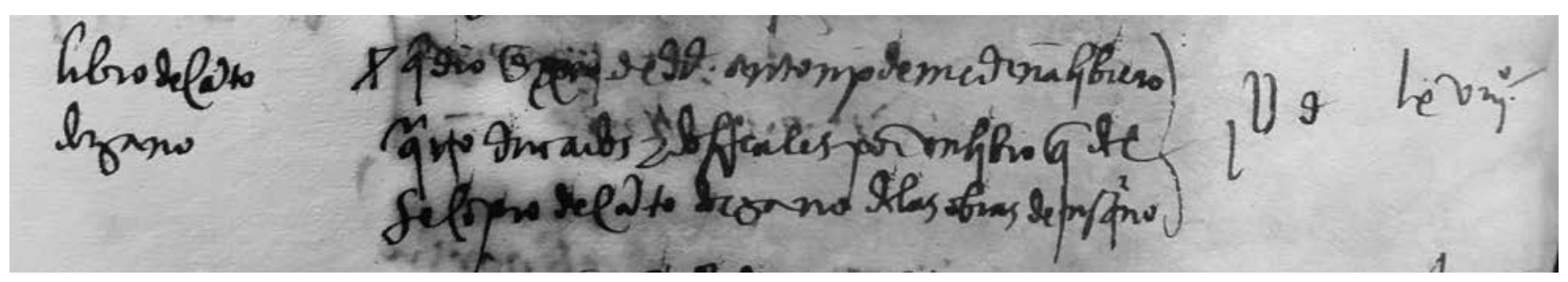

Ilustración 4. Pago al librero Antonio de Medina por un libro con obras de Josquin.

(Reproducida con autorización del Gobierno de la Santa Capilla).

En cuanto a la posibilidad de que se interpretasen en la Santa Capilla las obras habituales en la catedral, hay algo que llama poderosamente nuestra atención: el hecho de que el copista de libros de canto de órgano de la Santa Capilla sea, a partir de 1546, el mismo que el de la iglesia mayor, Alonso Fernández Becerra, quien copió diversos libros para San Andrés al menos en 1546, 1547, 1548, 1555, 1556 y 1566 , tanto por iniciativa propia como por encargo de la cofradía $^{139}$. Ello nos induce a pensar que el repertorio de ambas instituciones contendría muchas obras en común y que la música de los maestros de la catedral disfrutaría de una presencia importante en la parroquial. Además, hay que dar por hecho que el intercambio de materiales entre ambas capillas musicales, gracias a la movilidad de los músicos y a las redes sociales de los cantores, sería algo natural como ocurría en Granada entre la Capilla Real y la propia catedral. En este sentido, resulta muy revelador un inventario musical de la Catedral de Jaén fechado en 1548 que nos pone sobre la pista de los libros de polifonía al cuidado del entonces maestro catedralicio, Francisco Guerrero, cuyo contenido sería hipotéticamente conocido en San Andrés gracias a la labor del copista Alonso Fernández Becerra a mediados del siglo XVI (Ilustración 5).

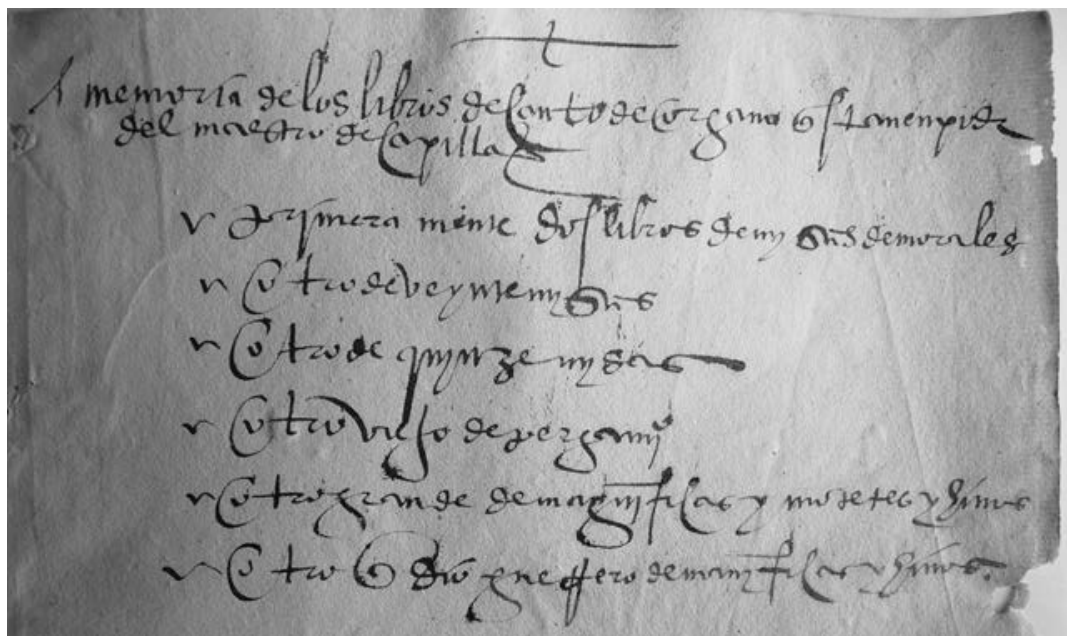

Ilustración 5. Inventario de los libros de polifonía de la Catedral de Jaén en $1548^{140}$. (Reproducida con autorización del Excmo. Cabildo Catedral de Jaén).

139 AHSCSAJ, $A C$, libro 2, s.f., 16-V-1546, 20-VI-1546, 21VIII-1547, 19-II-1548, 15-IX-1555, 19-I-1556; leg. 11, "Cuentas Hacienda 1551-1619", Libro de cuentas 1561-1578, s.f., descargo de 1567. Este copista tuvo un hijo llamado Alonso Becerra, natural de Jaén y formado en las catedrales de Jaén, Baeza y Córdoba que, siendo capellán de la iglesia mayor de Alcaudete y Valdepeñas, concurrió en 1577 a las oposiciones al magisterio de capilla de la Catedral de Málaga, donde quedó en segundo lugar tras Pedro Periáñez; al año siguiente aparece como maestro en la Catedral de Guadix; véase LLORDÉN, Andrés, 1961: 141-142; y CORRAL BÁEZ, Francisco Javier, 1999: 919.
140 AHDJ, leg. 448, "Libro de los ornamentos de la Santa Iglesia de Jaén, año de 1548”, s.f., última página, detalle. 
Los volúmenes mencionados pueden identificarse claramente: los "dos libros de misas de Morales" se corresponden con el Missarum Liber Primus y su Missarum Liber Secundus de Cristóbal de Morales, impresos ambos por primera vez en Roma por los hermanos Valerio y Ludovico Dorico en 1544 (RISM M3580 y M3582); reimpreso el primero en una versión casi idéntica por Jacques Moderne en Lyon en 1545 (RISM M3581) y el segundo en 1552 (M3583). Ambos volúmenes, dedicados respectivamente a Cosimo I de Médici y al Papa Paulo III, contenían un total de dieciséis misas, entre ellas su misa de difuntos, de amplia aceptación ${ }^{141}$. El "libro de veinte misas" no es otro que el Liber Viginti Missarum Musicalium (París, Attaingnant, 1532 $2^{1-7}$ ), una antología de veinte misas de autores franceses y francoflamencos editada en siete fascículos en formato de libro de coro $^{142}$. Más popularidad alcanzó aun si cabe el nombrado en el siguiente asiento, "otro de quince misas", identificable con el Liber Quindecim Missarum antes citado. La importancia de este libro, compuesto "per excellentissimos musicos" según señala el título, es fundamental, ya que fue la primera gran antología de música sacra publicada en Roma, de ahí que se convirtiese en modelo para colecciones análogas (incluidos los dos libros de misas de Morales) y que gozase de una amplia circulación en bibliotecas hispanas. Su cuidada preparación, simulando el diseño y formato de los libros manuscritos, y su dedicatoria al melómano papa León $\mathrm{X}$, representado en la portada junto al editor que le ofrece un libro con un canon (Vivat Leo Decimus Pontifex Maximus) (Ilustración 6), no debió de pasar desapercibida a su protonario apostólico. Los tres volúmenes citados sumaban medio centenar de misas de los más destacados compositores continentales y evidencian, por sí mismos, la importancia de las colecciones impresas en la diseminación del repertorio polifónico. Figuran a continuación tres de las recopilaciones manuscritas que contendrían el repertorio local: "otro [libro] viejo de pergamino", "otro grande de magníficats y motetes e himnos" y "otro que dio Guerrero de magníficats e himnos". Este último volumen es particularmente relevante, ya que contendría las versiones musicales más tempranas de los

141 Sobre la circulación de los impresos de Morales en España, véase KNIGHTON, Tess, 2007: 161-175.

142 Los compositores representados son Claude de Sermisy (Philomena praevia, IX Lectionum, Plurium motetorum, Requiem y Domini est terra), Nicholas Gombert (Quam pulcra es y Da pacem), Lupus Hellink (Jam non dicam y Panis quem ego dabo), Jean L'Héritier (Osculetur me y Impetum), Pierre de Manchicourt (Deus in adjutorium y Surge et illuminare), Jean Mouton (Tuae est potentia y D'Allemaigne), Jean Richarfort ( $O$ genitrix y Requiem), Antonius Divitis (Quem dicunt homines), Mattheus Gascogne (Nigra sum) y Johannes Prioris (Requiem). himnos de Guerrero, que publicaría en versión revisada y ajustada textualmente al Nuevo Rezado en su Liber Vesperarum de $1584^{143}$.

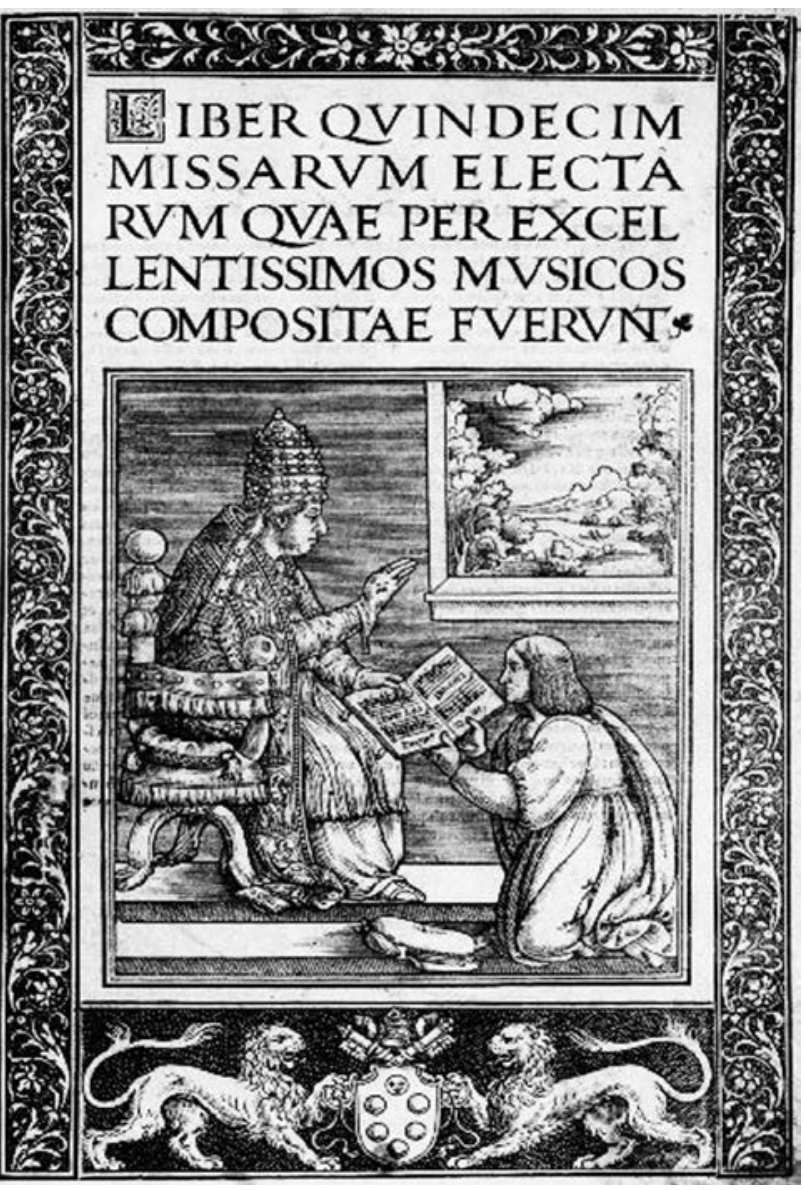

\section{Ilustración 6. Portada del Liber Quindecim Missarum de 1516.}

(Reproducción tomada de un repositorio institucional libre $)^{144}$.

143 El ciclo himnódico pretridentino de Guerrero, citado en el inventario de 1548, se ha conservado parcialmente en las catedrales de Guatemala y Toledo, tal y como estudiaron SNOW, Robert J., 1987: 178-201; y NOONE, Michael, 2003: 21-22.

$144 \mathrm{La}$ ilustración procede del ejemplar de la British Library [GB: Lbl K.9.a.12], disponible en el Royal Holloway Digital Repository $<$ https://repository.royalholloway.ac.uk/items/9245820b-59e6-4c1c979b-eec9c6fc4320/1/>. Existe otra digitalización de este libro, a partir de un ejemplar conservado en Bolonia [I: Bc R.169], en la Petrucci Music Library <http://imslp.org>. 
Un inventario de 1657 de la propia Catedral de Jaén confirma que tres de los cuatro volúmenes impresos citados en 1548 seguían en el archivo (se había perdido el libro de las veinte misas) y añade otros nombres internacionales conocidos en el ambiente musical jiennense del siglo XVI: Pierluigi Palestrina (ca. 1525-1594), el mítico maestro de la Cappella Giulia -la capilla musical de San Pedro de Roma-, o Thomas Crecquillon (ca. 1505/15-1557), miembro de la capilla flamenca del emperador Carlos $\mathrm{V}^{145}$. Por otro lado, dos inventarios de otra institución de patronazgo privado como era la Sacra Capilla de El Salvador de Úbeda, fechados en 1563 y 1568 , confirman la popularidad del repertorio veinte años después, pues en ellos reaparecen los libros de las quince y veinte misas y los dos libros de misas de Morales. Además, añade a este selecta nómina los nombres del ya mencionado Andreas de Silva, primero de los «cantores e musici secreti» en obtener la posición de maestro privado del papa León X, y Nicolas Gombert (ca. 1495-ca. 1560), maestro de la capilla flamenca de Carlos V, representado cada uno de ellos con un juego de cuatro libretes de motetes ${ }^{146}$. El precitado inventario de 1657 contiene colecciones de otros compositores del siglo XVI ya difuntos en la época como Francisco Guerrero o Tomás Luis de Victoria, algunas de cuyas obras previsiblemente llegarían a la Santa Capilla de manera impresa o manuscri$\operatorname{ta}^{147}$, de la misma manera que lo hicieron a otras capillas musicales de la diócesis como la de la Catedral de Baeza ${ }^{148}$.

\section{DOS VERSOS INTRUMENTALES DE GIL DE ÁVILA}

Si en lo que respecta al repertorio foráneo es posible establecer algunas hipótesis, no podemos decir lo mismo en lo relativo a los maestros al servicio de la Santa Capilla, cuya producción musical se ha perdido de manera generalizada. En este contexto, adquiere particular relevancia la aparición de dos juegos de fabordones o versos instrumentales atribuidos claramente a Gil de Ávila (o "Dávila", como también se le cita), maestro de capilla entre 1595 y 1597, en el Ms. 19

145 El inventario de Jaén fue dado a conocer de manera preliminar en 1990 por Pedro Jiménez Cavallé. Más recientemente Javier Marín López ha acometido una identificación completa de sus registros y un amplio estudio en el contexto de otros inventarios ibéricos del siglo XVII; véase JIMÉNEZ CAVALLÉ, Pedro, 1990: 67-76; y MARÍN LÓPEZ, Javier, 2015: 108-160.

146 GALERA ANDREU, Pedro, 2012: 130.

147 En concreto, se citan de Victoria sus colecciones impresas de misas (1576), himnos (1581), magníficats (1581), misas (1592) y su antología de música sacra (1600), y de Guerrero su primer y segundo libro de misas (1566 y 1582, respectivamente), sus magníficats (1563) y sus motetes (1597), entre otros libros.

148 MARÍN LÓPEZ, Javier, 2007: 319-346. de la Catedral de Puebla [MEX: Pc 19]; un libro con música para ministriles probablemente copiado en 1672 por el instrumentista José de Burgos, si bien la mayor parte del repertorio que contiene es del siglo XVI ${ }^{149}$. Se trata de un caso más de compositor activo en instituciones andaluzas cuya obra musical se conserva al otro lado del Atlántico ${ }^{150}$. Aunque no es posible determinar si estas piezas fueron concebidas para la Santa Capilla, dada la zigzagueante carrera desarrollada por Ávila y su fugaz paso por Jaén, su mera localización constituye una noticia que ha de recibirse con entusiasmo: son las únicas obras conservadas de un maestro al servicio de la venerable cofradía y su estilo musical no sería muy distinto del que interpretasen los chirimías de Jaén en aquel tiempo.

El Ms. 19 es la típica antología de música para ministriles, compartiendo repertorio y características con los otros tres libros de facistol de origen español con música instrumental: el Ms. 975 de la Biblioteca Falla de Granada [E: GRmf 975] (copiado en la década de 1560, probablemente para la Capilla Real de Granada) y los dos códices de Lerma (conservados uno en la propia iglesia de San Pedro de Lerma [E: LERC 1], y otro -Lerma Codex-en la Universidad de Utrecht [NL: $U u$ 3.1.16], y copiados en torno a 1590) ${ }^{151}$. Puebla 19 se inicia con una serie de versos instrumentales en orden modal ascendente para el Oficio (sección donde figura Ávila) y le siguen 9 himnos de polifonistas ibéricos, 27 canciones o madrigales de autores internacionales, 8 motetes, un fragmento de misa y una sección final con 6 canciones de maestros peninsulares. La fama que Ávila tuvo en su época debió de ser alta, a tenor de los emblemáticos autores con los que comparte protagonismo en el manuscrito poblano: Orlando di Lasso, Clément Jannequin, Thomas Crecquillon o Philippe Rogier entre los extranjeros; Francisco Guerrero, Hernando Franco, Juan Navarro, Rodrigo de Ceballos y Pedro Rimonte entre los peninsulares ${ }^{152}$. Sus obras debieron incorporarse al repertorio de ministriles y seguramente fueron llevadas a Nueva España por algún maestro de capilla o instrumentista, situación que pudo verse favorecida por la estancia de Gil de Ávila en Sevilla, puerto y puerta de Indias.

Las dos piezas atribuidas a Ávila son fabordones o juegos de versos instrumentales. A diferencia del fabordón vocal, que consiste básicamente en la armonización homofónica de una fórmula salmódica escrita a cuatro voces -aunque puede

149 Archivo del Venerable Cabildo de la Catedral de Puebla, $A C$, libro 16, f. 200v, 12 agosto 1672.

150 Sobre la difusión de los compositores andaluces en Hispanoamérica, véase MARÍN LÓPEZ, Javier, 2010: 95-132.

151 Para una visión de conjunto sobre el repertorio y funciones de estos libros, véase RUIZ JIMÉNEZ, Juan, 2004: 199-239.

152 Para un inventario de Puebla 19, véase KREITNER, Kenneth, 2009: 282-285. 
ser a más o a menos- que declaman silábicamente el texto, el fabordón instrumental presenta una mayor variedad estilística, con versos y secciones rigurosamente imitativas ${ }^{153}$. Estos fabordones para ministriles estaban destinados a interpretarse en el Oficio de las Horas en alternancia ya sea con el canto llano, con la capilla vocal y/o con el órgano (o con todos juntos), ofreciendo un cuadro sonoro de notable variedad tímbrica. Este tipo de alternancias se daba en las Salves, magníficats, himnos y en especial en los salmos, de ahí que generalmente se asignen los versos a uno de los tonos salmódicos, cuyas fórmulas en los fabordones instrumentales son tratadas con mayor libertad que en los vocales. Así, el primero de los juegos (ff. $31 v-35 r$ ), es a cuatro voces, para sexto tono y se integra por 7 versos. El segundo de los juegos (ff. 38v-43r) es también para sexto tono, pero aumenta el número de voces a cinco; su número de versos, en cambio es menor (5), lo que haría posible su interpretación en rígido alternatim en un salmo de 10 versos como Dixit Dominus (n $\left.{ }^{\circ} 109\right)$, Laudate Pueri (no. 112) o Lauda Jerusalem (no. 147), todos ellos de uso frecuente en las Vísperas de los domingos y demás fiestas "de guardar". Sin embargo, no hay que descartar que estos versos se interpretasen en un orden distinto al que están en el manuscrito o se repitiesen para adecuarse al número específico de versos de un determinado salmo y al plan de alternancia establecido con el canto llano, la capilla vocal y el órgano. Asimismo, es probable que, en aras de la mayor variedad, los versos repetidos se interpretasen con glosas o adornos improvisados por los ministriles, y que hubiese cambios de instrumentación de un verso a otro, utilizando los principales tipos sonoros (chirimías, cornetas, sacabuches, bajones y flautas), tanto puros como mezclados, prácticas todas ellas ampliamente respaldadas en la documentación de la época ${ }^{154}$.

El contraste antes mencionado a propósito del timbre aflora en la propia música que, si bien se mueve en el marco de las convenciones propias de la construcción polifóni-

$153 \mathrm{El}$ término, que podía obedecer a realidades musicales muy distintas dependiendo de la época, la institución y su carácter vocal o instrumental, se utilizaba tanto en su forma adverbial («a fabordón» o «en fabordón») para referirse a un estilo o práctica de canto, como de manera sustantivada («fabordón») en alusión a las piezas así compuestas; véase ZAUNER, Sergi, 2015: 47-77. Existía otra acepción del término fabordón, fuera del ámbito litúrgico, alusiva a la práctica de "improvisar nuevas voces sobre una melodía preexistente utilizando terceras paralelas por debajo y cuartas por encima de la voz principal", es decir, una tradición popular de polifonía; véase FIORENTINO, Giuseppe, 2013: 1854-63.

154 Resultan representativas, en este sentido, las conocidas instrucciones dadas por Guerrero a los ministriles de la Catedral de Sevilla en 1586; véase GONZÁLEZ BARRIONUEVO, Herminio, 2000: 250. Existe una explicación más detallada sobre la interpretación de los versos de ministriles en KIRK, Douglas, 1993: vol. 1, 130-137. ca de su tiempo, presenta un fuerte sabor modal y un cierto arcaísmo compositivo en las resoluciones armónicas y en la conducción melódica. Así, es notoria la búsqueda de variedad textural contraponiendo secciones homofónicas con otras contrapuntísticas, y no sólo entre versos sino dentro de cada uno de ellos, divididos ocasionalmente en dos mitades (como ocurre en el verso $6^{\circ}$ del juego a 4 voces y el verso $1^{\circ}$ del juego a 5). También contribuye a esta diversidad el enfrentamiento de bloques sonoros en valores largos -de semibreve y mínima-con ágiles diseños de figuras cortas -como semimínimas y corcheas- (como se aprecia en los versos $1^{\circ}, 4^{\circ}, 5^{\circ}$ y $6^{\circ} \mathrm{del}$ juego 4 y los versos $2^{\circ}, 3^{\circ}$ y $4^{\circ}$ del juego a 5). Cabe señalar que los versos a 4 están escritos en un contrapunto más fluido e imitativo que los versos a 5, en general más homofónicos y solemnes; las distintas imitaciones del primer juego se producen en contrapunto simple -como los versos $2^{\circ}$ y $7^{\circ}-$ o a dúo -versos $4^{\circ}$ y $5^{\circ}-$. Si en el primer juego, Ávila aporta variedad a través de la rítmica, con desplazamientos de la acentuación y el uso de contratiempos (cc. 15-18, 43-51 o 131-141), en el segundo opta por permanecer más sujeto al tactus, con grupos de acordes en mínimas y semimínimas, principalmente. Pese a sus marcadas diferencias, ambas obras están escritas en compás binario, pero terminan con un verso en ritmo ternario con unidad de pulso en semibreve; este cambio métrico obedecía al hecho de que, por convención, algunos salmos y cánticos con los que estos versos alternaban presentaban un cambio de mensuración en los versículos conclusivos de la Doxología Menor ("Gloria Patri”).

Este breve análisis indica que, frente al resto de géneros representados en estas antologías de ministriles (en su mayor parte, versiones para instrumentos de motetes o canciones de origen vocal), los versos de Ávila parecen haber sido concebidos originariamente para su interpretación instrumental. Esta circunstancia, unida a su cotidiana presencia en el servicio de Vísperas, hacía de estas miniaturas polifónicas, escritas con pretensiones más funcionales que estéticas, uno de los géneros más característicos y asiduamente interpretados por los ministriles de la época. Dada su rareza y originalidad y el hecho de que apenas se conozcan ejemplos de este género en los siglos XVI y XVII ${ }^{155}$, ofrecemos transcripción completa de ambos juegos, que sirve de complemento a su reciente grabación discográfica ${ }^{156}$. Esperamos de esta manera haber

155 Entre los escasos ejemplos de versos para ministriles del siglo XVII figuran los de Zaragoza (anónimo) y Quito (Manuel Blasco); véase STEVENSON, Robert, 1970: ejemplo musical 2, 1-4; y GONZÁLEZ MARÍN, Luis Antonio, 1993: 211-219.

156 Ministriles Novohispanos. Obras del manuscrito 19 de la Catedral de Puebla de los Ángeles, Ensemble La Danserye. Notas al libreto de Javier Marín López. Madrid, Sociedad Española de Musicología, serie ‘El patrimonio musical hispano' no 31, DISCAN/DCD309, 
contribuido al conocimiento de la música practicada durante el siglo XVI en uno de los grandes centros de producción, consumo, difusión y enseñanza musical del Jaén renacentista: la Santa Capilla de San Andrés.

\section{TRANSCRIPCIÓN DE DOS JUEGOS DE VERSOS PARA MINISTRILES DE GIL DE ÁVILA}

\section{Criterios de edición}

- Nombre de las voces. Se han normalizado ortográficamente, añadiendo un número en romano -por orden de altura- a las voces de idéntico nombre para su correcta diferenciación. En el primer sistema se han mantenido las denominaciones completas, que en los siguientes se han abreviado con S I para Superius I, S II para Superius II, A para Altus, T para Tenor y B para Bassus.

- Claves y armaduras. Se han modernizado las claves, sol 2 para S I, S II y A; sol 2 octavada para T; y fa 4 para B. Se conservan las armaduras primigenias, ya que no se ha realizado ningún transporte tonal.

- Compás. Los compases usados originalmente en las dos obras son $2 / 4$, con unidad de pulso en mínima, y $3 / 2$, con unidad de pulso en semibreve. Para facilitar la interpretación, hemos realizado la transcripción con la misma unidad de pulso pero duplicando el compás, aplicando así las convenciones rítmicas actuales y convirtiendo el $2 / 4$ en $2 / 2$ y el $3 / 2$ en $3 / 1$.

- Modificaciones del original. Los pasajes, notas o signos que se han modificado en la edición por error obvio del copista, por ser discutibles o por impedir el correcto estudio e interpretación de la obra, se recogen en el aparato crítico, señalando el verso, el número de compás, nota afectada en superíndice, abreviatura de la voz y la modificación realizada.

- Alteraciones accidentales. Como norma general se mantienen todas, suprimiéndose las redundantes y las que implican una disonancia armónica evidente -explicada y resuelta en el aparato crítico-. Los sostenidos que anulan el bemol de la armadura han sido sustituidos por becuadros. Cuando una nota está alterada y se sobreentiende que se repite así al inicio del siguiente compás, se incorpora la alteración en el propio pentagrama. Las alteraciones añadidas por motivos melódicos, armónicos o estilísticos -como las fictas- se sitúan encima de la nota; las sugeridas o dudosas se encuentran entre corchetes. Los demás cambios se anotan en el aparato crítico.

2013, pistas 8-12 y 29-35. Recomendamos también la amplia reseña de este CD realizada por KIRK, Douglas, 2014: 663-671. Los versos de sexto tono se estrenaron en 2012 en el marco del Festival de Música Antigua de Úbeda y Baeza; véase MARÍN LÓPEZ, Javier y SÁNCHEZ LÓPEZ, Virginia (eds.), 2012: 95-98.
- Barrado. Aunque la notación mensural del manuscrito no contiene líneas de separación de compás, se han añadido siguiendo las pautas modernas para favorecer su estudio e interpretación.

- Ligaduras y ennegrecimientos. Las ligaduras se indican con un corchete horizontal sobre las notas unidas en el original. Los ennegrecimientos característicos de la notación hispana, que avisan del desplazamiento de la acentuación -como síncopas y hemiolias-, han sido señalados sobre el mismo pasaje ennegrecido en el manuscrito con un ángulo recto, direccionado a la derecha para señalar el inicio y a la izquierda para el final. Las notas que, aun precisándolo, no han sido ennegrecidas por olvido o error del copista también han sido marcadas por coherencia con el resto; en estos casos se ha hecho entre corchetes como añadido editorial.

- Plicas. El copista escribe todas las corcheas con las plicas separadas. Como la música no contiene letra alguna, y la agrupación o no de las plicas no implica aquí diferenciación silábica o prosódica, hemos determinado juntarlas atendiendo al pulso del compás moderno utilizado en cada caso.

- Íncipit musical. Al comienzo de la obra presentamos el íncipit, con las claves, armadura, notas (dos compases completos) y silencios de cada voz tal y como están en el manuscrito. Se ha confeccionado a partir de la notación original usada por el copista de $M E X: P c 19$, cuyos elementos han sido seleccionados y digitalizados expresamente para esta edición. A continuación se añade un compás con el rango completo de la tesitura de las voces, de agudo a grave, marcadas con dos figuras simples de cabeza ennegrecida.

\section{Aparato crítico}

Versos de sexto tono a 4 (MEX: Pc 19, ff. 31v-35r)

Esta obra está escrita en claves altas: sol 2 para S i y $\mathrm{S}$ II, do 2 para el A y do 4 para el B. Según las prácticas de la época convendría un transporte de cuarta descendente, pero al realizarlo el A queda excesivamente grave, convirtiéndose en un tenor, lo que plantearía una incongruencia terminológica en las tesituras. Además, el Verso de sexto tono a 5 , usando claves bajas para A, T y B, también presenta clave de sol en S I y S II, sin estar en este caso justificado el transporte y presentando tesituras similares en S I y S II. Por todo ello, por mantener la unidad de las dos obras en $f a$ y por conservar la configuración modal característica del sexto tono salmódico, hemos decidido editar la pieza sin transporte alguno.

VERSO $1^{\circ}$, ff. $31 \mathrm{v}-32 \mathrm{r}$.

- c. $19^{1-2}, \mathrm{~S}$ I: algunas de las alteraciones accidentales que presenta este manuscrito parecen añadidas con posterioridad a la copia original; en algunos casos proponen una armonía dura, inadecuada o fuera de estilo. En esta ocasión, 
aunque las alteraciones imprimen cierta brusquedad, hemos visto conveniente dejar los dos $f a$ sostenidos semimínimas por no presentarse un error evidente -añadiendo por coherencia armónica la propuesta de alteración a los dos fa mínimas del c. $19^{1-2}, S_{\text {II }}$ que no están presentes en el códice-; si bien recomendamos que todos los $f a$ del pasaje se interpreten sin sostenidos.

- c. 23, S II: originalmente un la breve con calderón; cambiamos por un la semibreve con calderón para cuadrar el $\mathrm{S}$ I con la cadencia realizada por el resto de las voces.

VERSO $2^{\circ}$, ff. $31 \mathrm{v}-32 \mathrm{r}$.

- c. $48^{3}, \mathrm{~S}$ II: originalmente un sol semimínima. Parece una errata del copista ya que esta figura, tal y como está, resta medio tiempo a la melodía a partir de ese punto, provocando un desajuste entre esta voz y las tres restantes; por ese motivo, ha sido cambiada por un sol mínima.

- c. $50^{3-4}, \mathrm{~S}$ I: originalmente dos $f a$ sostenidos semimínimas. Tal como está en la copia nos obligaría a alterar de igual forma los dos $f a$ del c. $50^{3-4}$, S II y el $f a$ corchea del c. $51^{1}$, S II -que no aparecen en el manuscrito-, generándose, además de una brusca modulación armónica, una disonancia con los si bemoles de $\mathrm{S}_{\text {I y }} \mathrm{B}$ que resulta inadecuada desde nuestro punto de vista. Por tanto, se ha cambiado por dos $f a$ naturales semimínimas.

VERSO $3^{\circ}$, ff. $32 \mathrm{v}-33 \mathrm{r}$.

- cc. 82-85, A: originalmente un do breve con calderón; cambiamos por un do longa con calderón para cuadrar el A con la cadencia realizada por el resto de las voces.

VERSO $4^{\circ}$, ff. $32 \mathrm{v}-33 \mathrm{r}$.

- cc. 109-112, S II: originalmente un do breve con calderón; cambiamos por un do longa con calderón para cuadrar el S II con la cadencia realizada por el resto de las voces.

VERSO 5 ${ }^{\circ}$, ff. $33 \mathrm{v}-34 \mathrm{r}$.

- c. 144, S II: originalmente un do breve con calderón; cambiamos por un do semibreve con calderón para cuadrar el $\mathrm{S}$ II con la cadencia realizada por $\mathrm{S}$ i y $\mathrm{B}$.

- c. 144, A: originalmente un la breve con calderón; cambiamos por un la semibreve con calderón para cuadrar el A con la cadencia realizada por S i y B.

VERSO $6^{\circ}$, ff. $33 \mathrm{v}-34 \mathrm{r}$.

- c. $149^{1}, \mathrm{~S}$ I: originalmente un la mínima con puntillo. Se trata de un error del copista, un añadido posterior o una marca accidental, ya que en ningún caso puede ser una prolongación de la figura que le antecede; por tanto, ha sido eliminado el puntillo sin más indicio dejando un la mínima.
- c. 172, S II: originalmente un la breve con calderón; cambiamos por un la semibreve con calderón para cuadrar el $\mathrm{S}$ II con la cadencia realizada por el resto de las voces.

VERSO $7^{\circ}$, ff. 33v-34r.

- c. 191, S II: originalmente un do breve sostenido con puntillo y calderón. Se ha eliminado la alteración por generar una fuerte disonancia con A y $\mathrm{B}$; cambiamos por un $d o$ breve natural con puntillo y calderón.

\section{Versos de sexto tono a 5 (MEX: Pc 19, ff. 38v-43r) VERSO $1^{\circ}$, ff. 38v-39r.}

- cc. 19-21, S I: originalmente dos silencios de semibreve. Se trata de un error de copia, ya que para encajar esta voz con las otras cuatro faltaría un silencio de semibreve más; cambiamos por tres silencios de semibreve.

VERSO $2^{\circ}$, ff. 39v-40r.

- cc. $52^{3-4}$ y 53 , A: originalmente un mi semimínima, un $d o$ mínima, un $s i$ bemol semimínima y un $d o$ mínima. El pasaje de esta línea melódica es disonante con el conjunto, parece transportado por error una segunda baja; cambiamos por un $f a$ semimínima, un re mínima, un do semimínima y un re mínima por coherencia armónica y modal del A con el resto de las voces.

- c. 70, A: originalmente un do breve con calderón; cambiamos por un do semibreve con calderón para cuadrar esta voz con la cadencia realizada por el resto de las voces.

VERSO $3^{\circ}$, ff. 40v-41r.

- cc. 108-110, A: originalmente un $f a$ breve con calderón; cambiamos por un $f a$ breve con puntillo y calderón para cuadrar esta voz con la cadencia realizada por el resto de las voces.

VERSO $4^{\circ}$, ff. $41 \mathrm{v}-42 \mathrm{r}$.

- cc. 131-133, A: originalmente un do breve con calderón; cambiamos por un $d o$ breve con puntillo y calderón para cuadrar esta voz con la cadencia realizada por el resto de las voces.

VERSO $5^{\circ}$, ff. $42 \mathrm{v}-43 \mathrm{r}$.

- cc. 147-149, S II: originalmente un sol breve con puntillo, un $f a$ semibreve, un sol mínima, un re semibreve, un $m i$ mínima, un $f a$ semibreve, un silencio de mínima, un la mínima y un si bemol semibreve. Aunque de este modo la voz se ajusta correctamente en el conjunto hasta el último compás, este pasaje genera fuertes disonancias con la armonía general, y el motivo rítmico en el c. 148 -semibreve-mínima / semibreve-mínima- presenta una configuración impropia de la tendencia a contratiempo del resto del verso. Además de dejarlo tal y como está en el manuscrito -con las complica- 
ciones expuestas-, existirían dos posibilidades editoriales: modificar la altura de las notas disonantes - principalmente subir una segunda mayor los dos $f a$ semibreves- o eliminar el puntillo del sol breve, si bien hay que añadir un silencio de semibreve antes del silencio de mínima en el c. $149^{2}$. Hemos elegido la segunda opción, que permite un mejor ajuste de la armonía, y que el motivo rítmico del c. 148 retome la configuración a contratiempo del movimiento y coincida en su configuración con el c. 141, S II. Por tanto, cambiamos por sol breve, un $f a$ semibreve, un sol mínima, un re semibreve, un mi mínima, un $f a$ semibreve, un silencio de semibreve, un silencio de mínima, un la mínima y un si bemol semibreve. 


\section{Versos de sexto tono a 4}

Fuente: $M E X: P c 19$, ff. $31 \mathrm{v}-35 \mathrm{r}$

Gil de Ávila (fl. 1574-1597)

Edición: J. Marín, V. Sánchez,

J. A. Gutiérrez y P. Jiménez

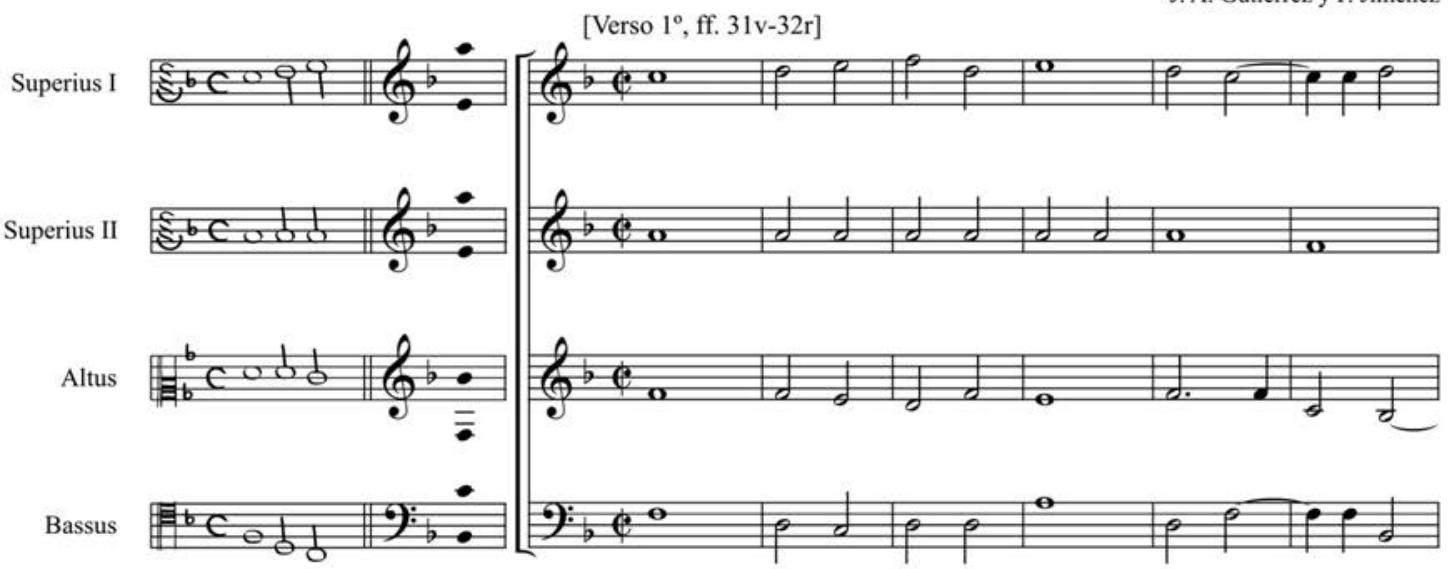

S I

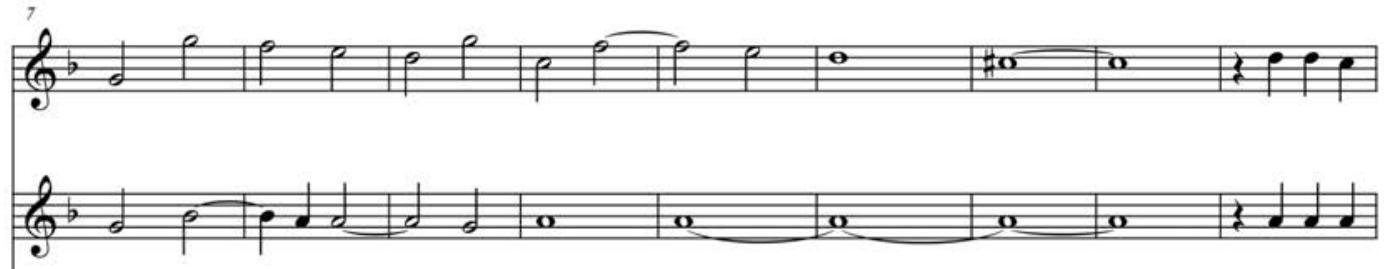

A

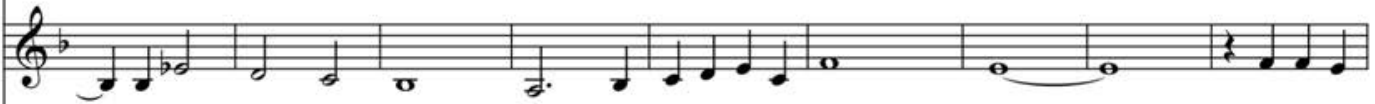

B

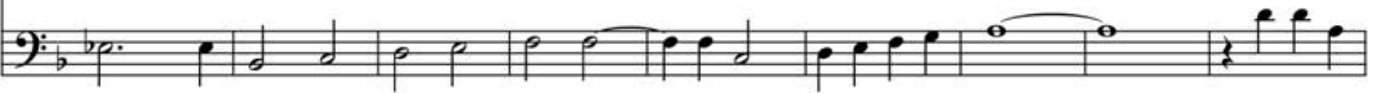

S I

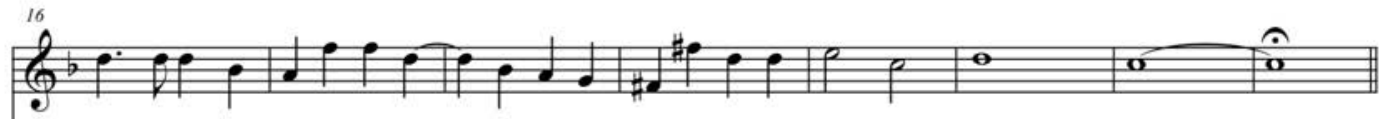

S II

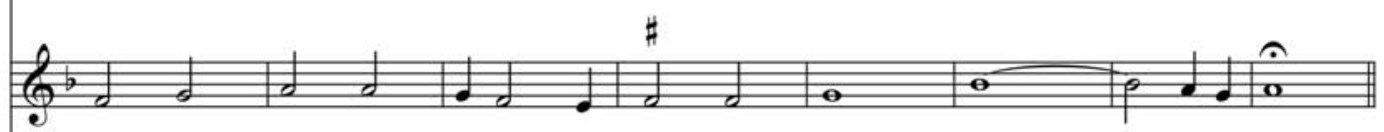

A

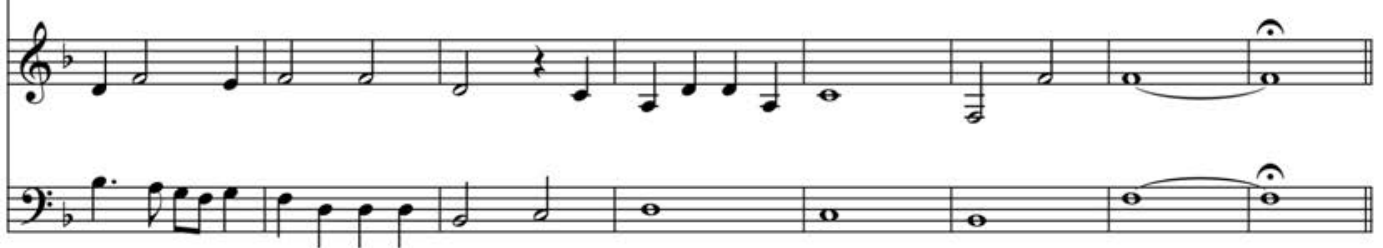



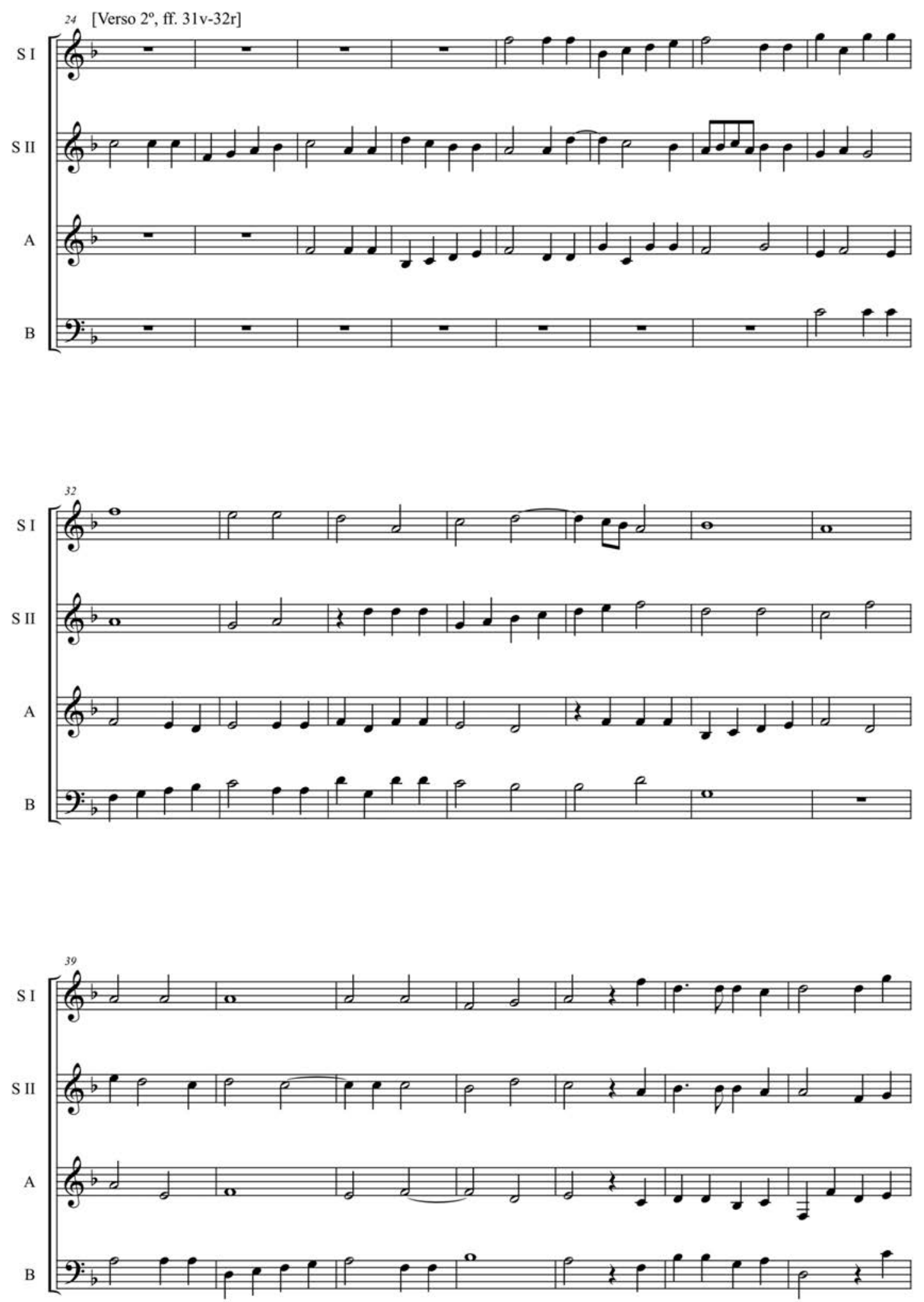

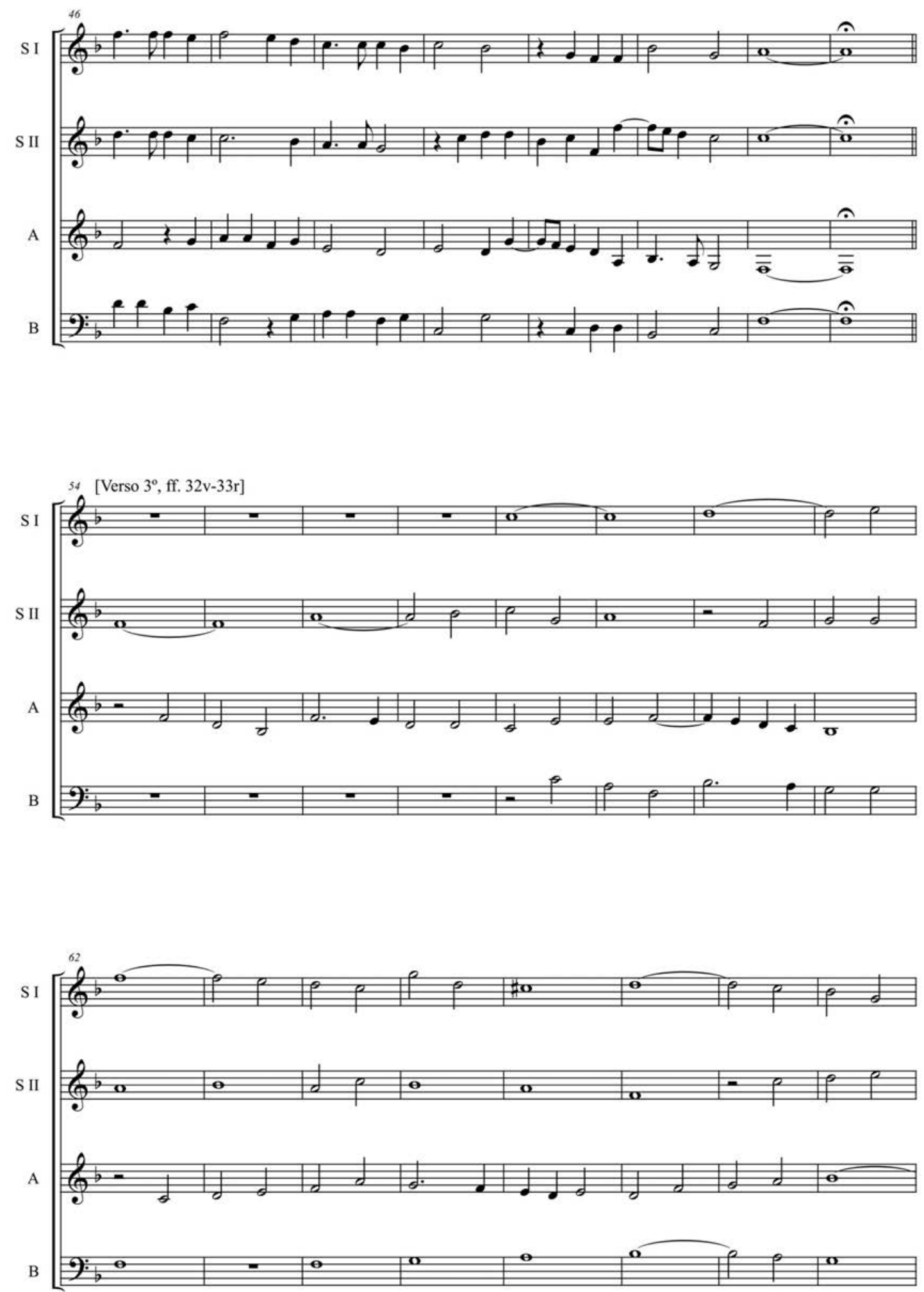

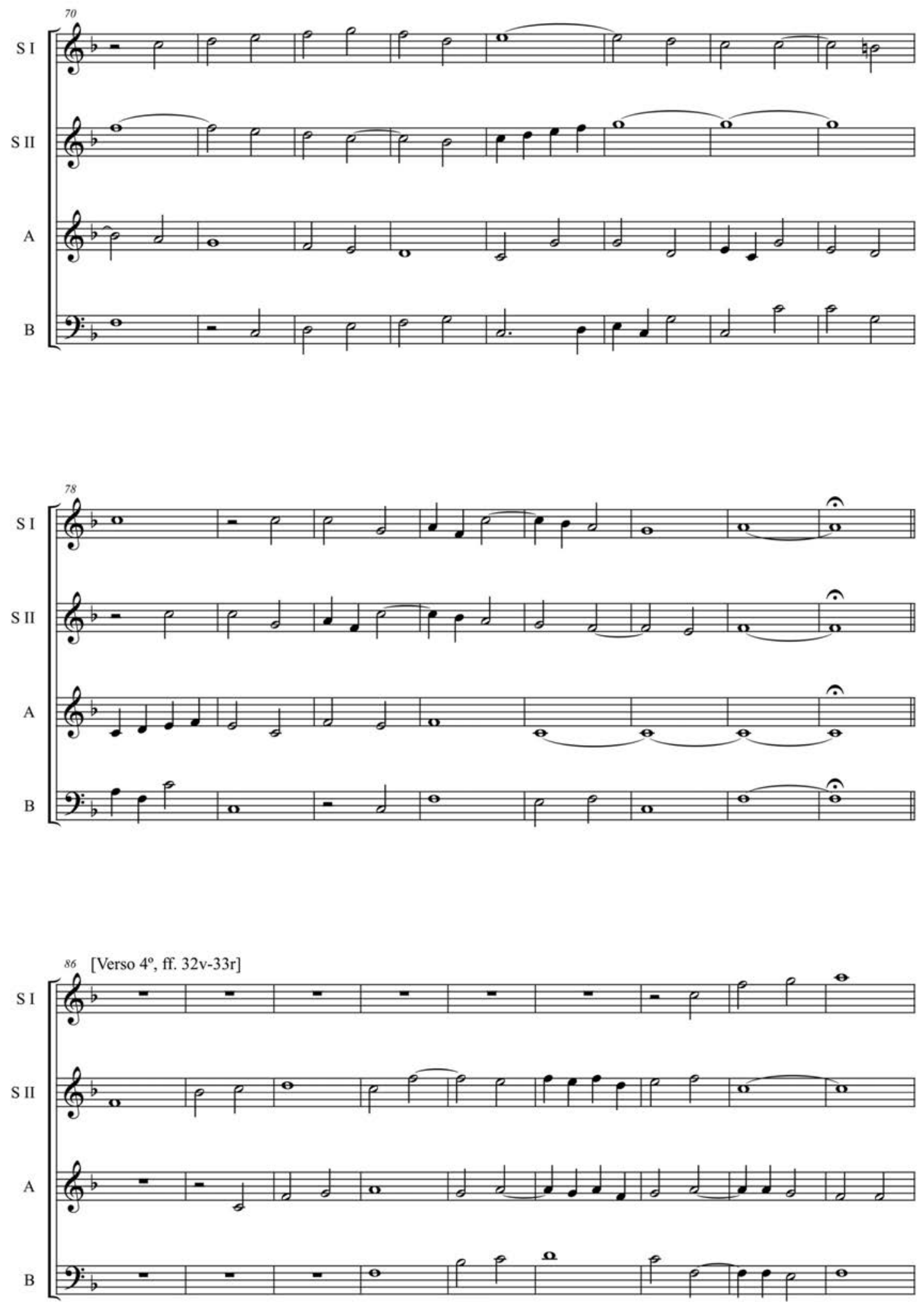

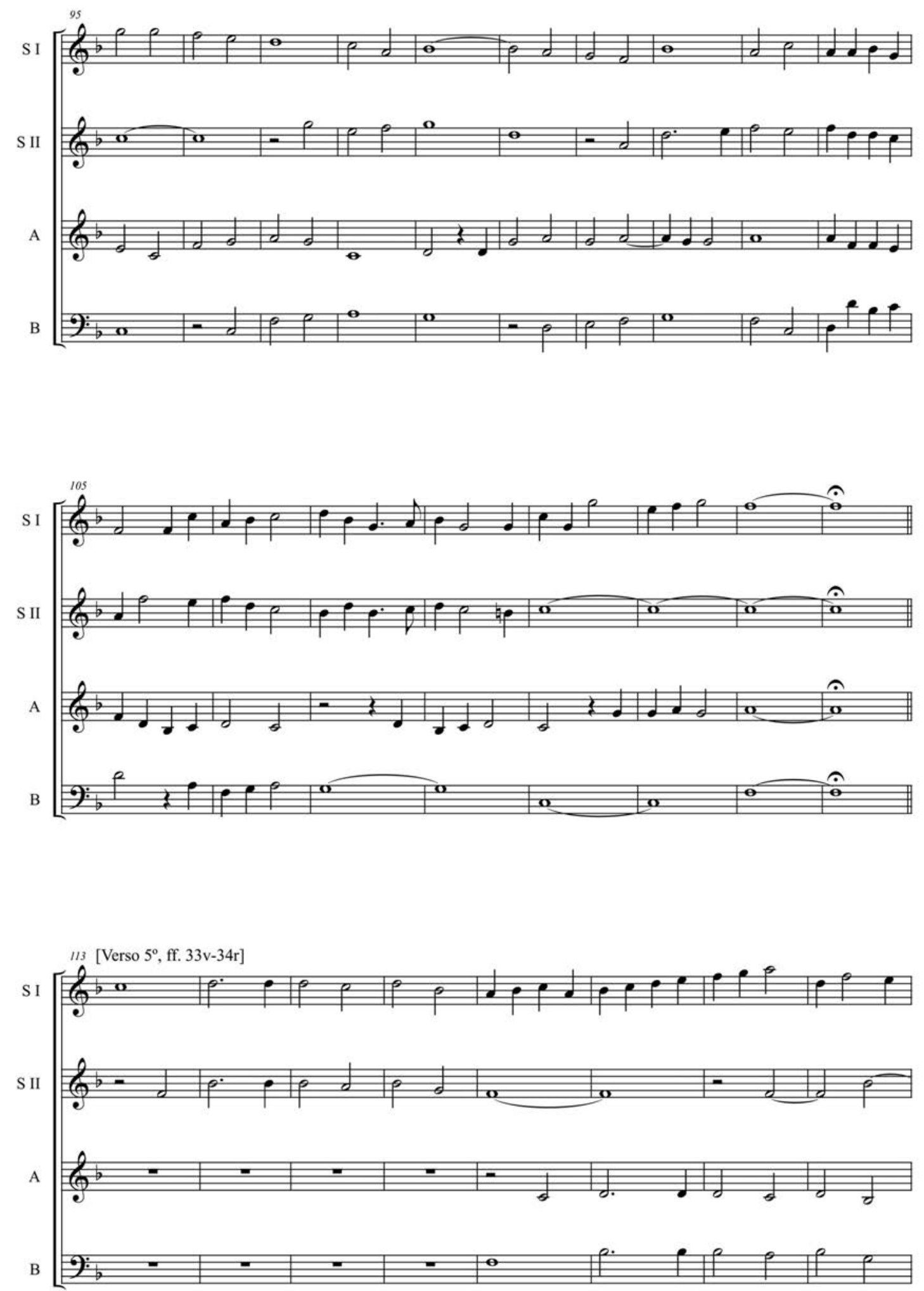

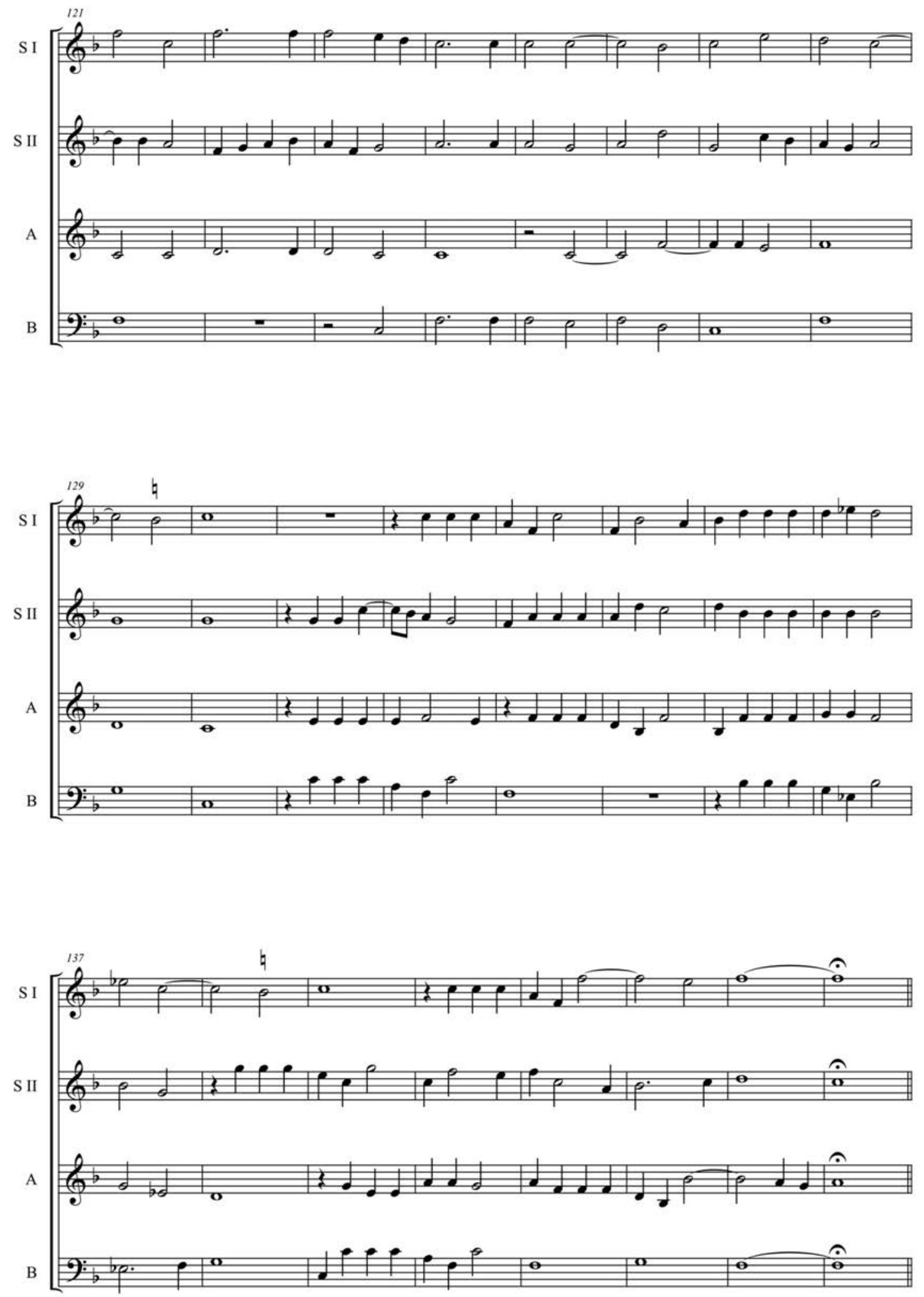

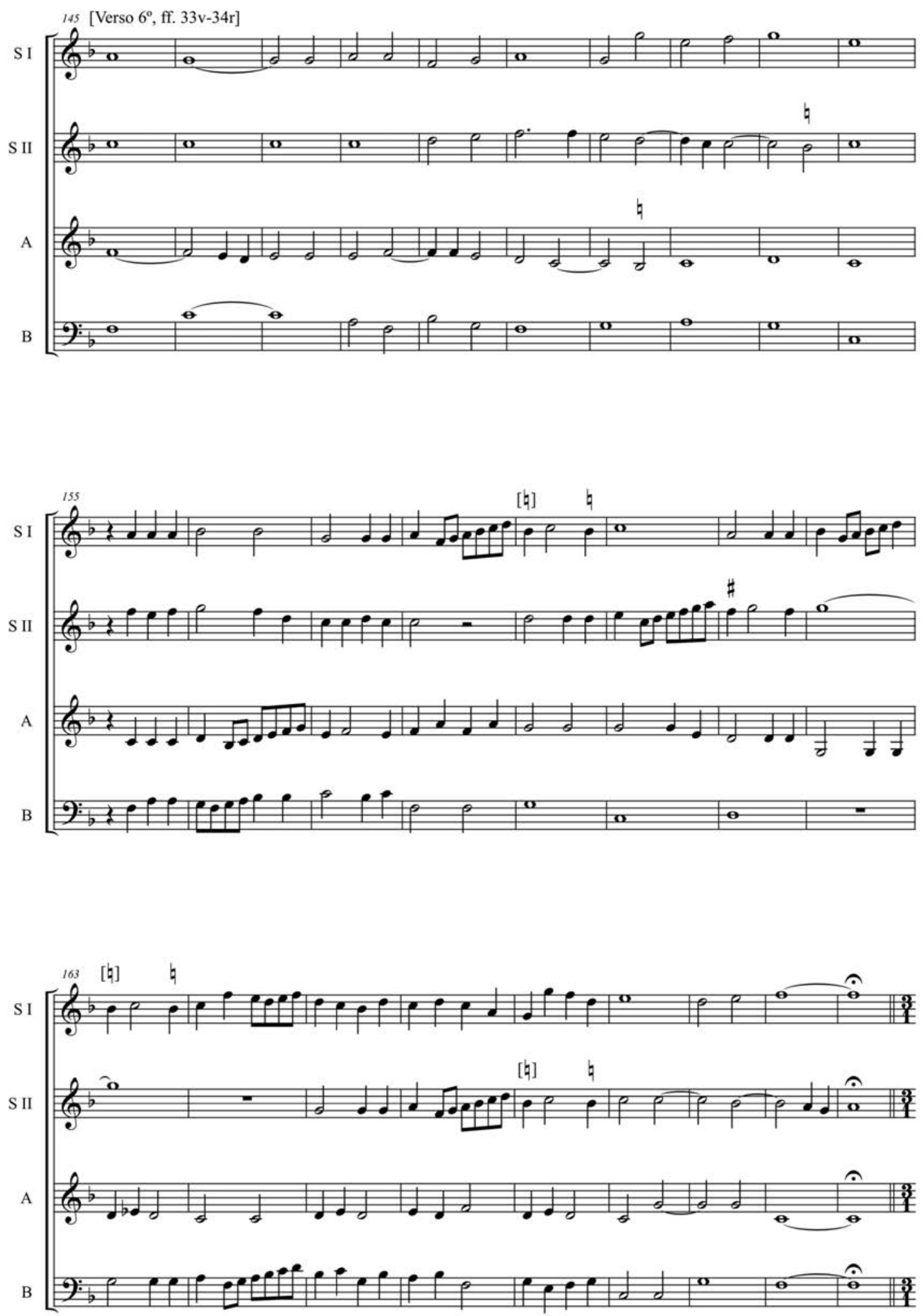

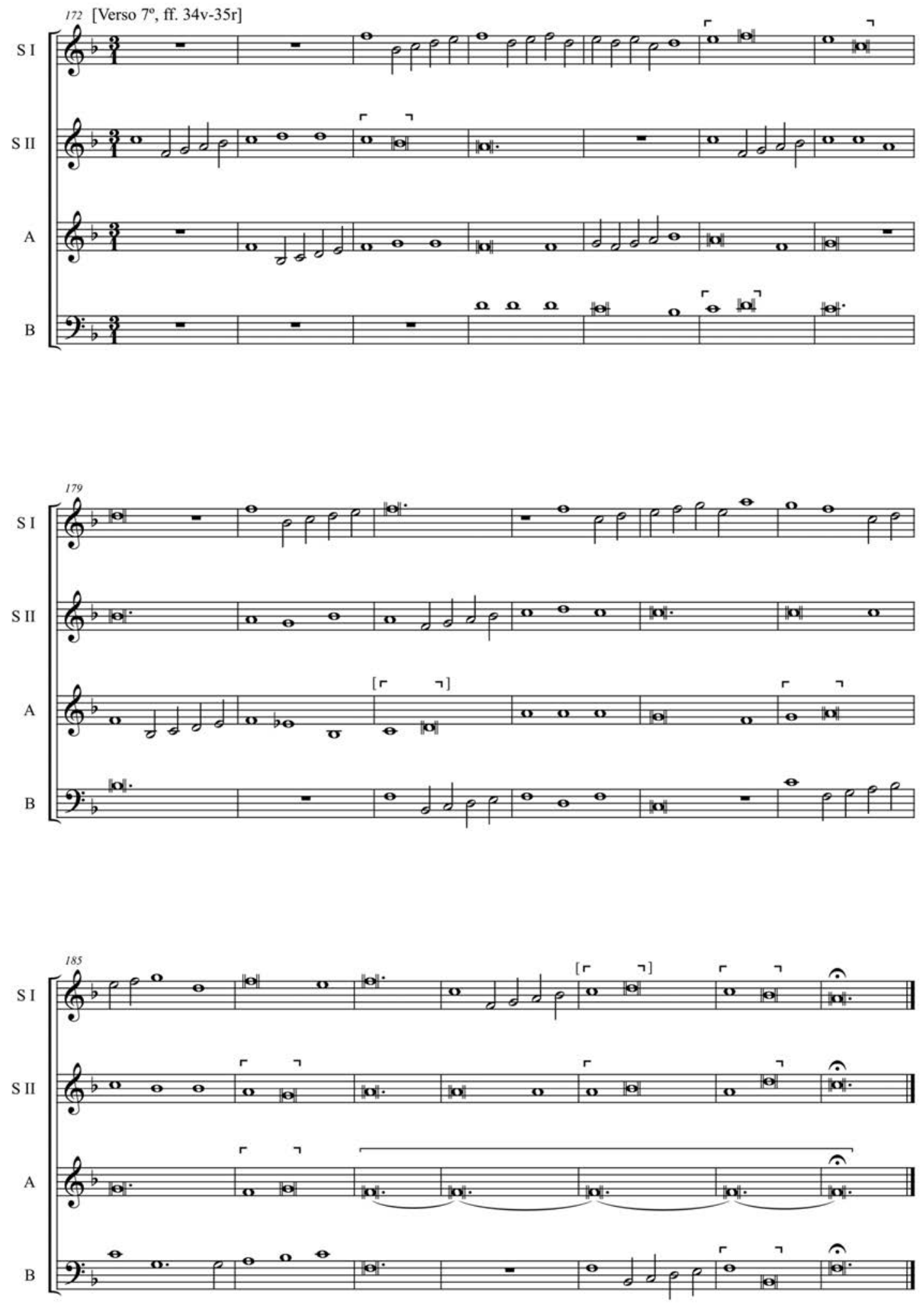


\section{Versos de sexto tono a 5}

Fuente: $M E X: P c 19$, ff. $38 \mathrm{v}-43 \mathrm{r}$
Gil de Ávila (fl. 1574-1597)

Edición: J. Marín, V. Sánchez, J. A. Gutiérrez y P. Jiménez
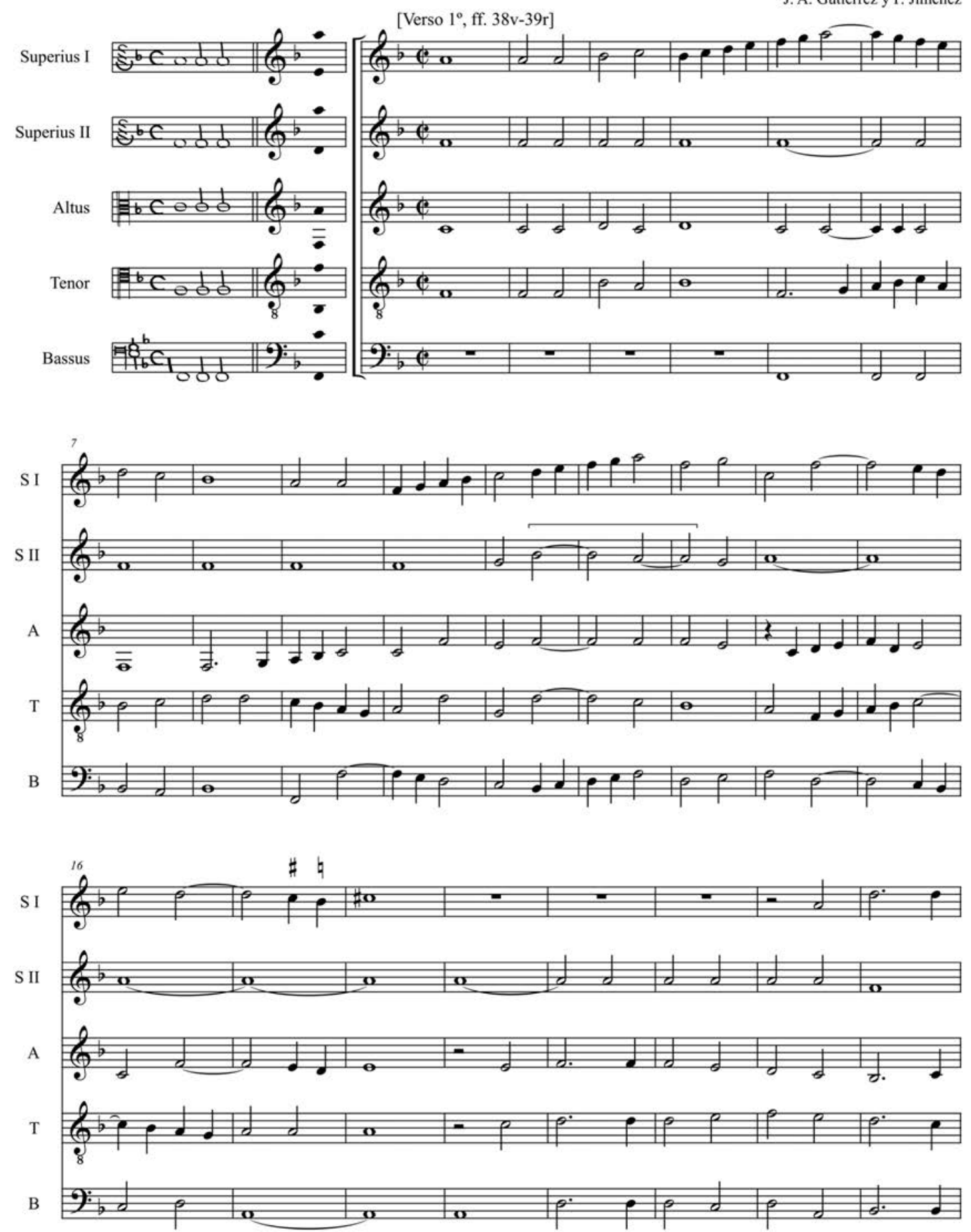

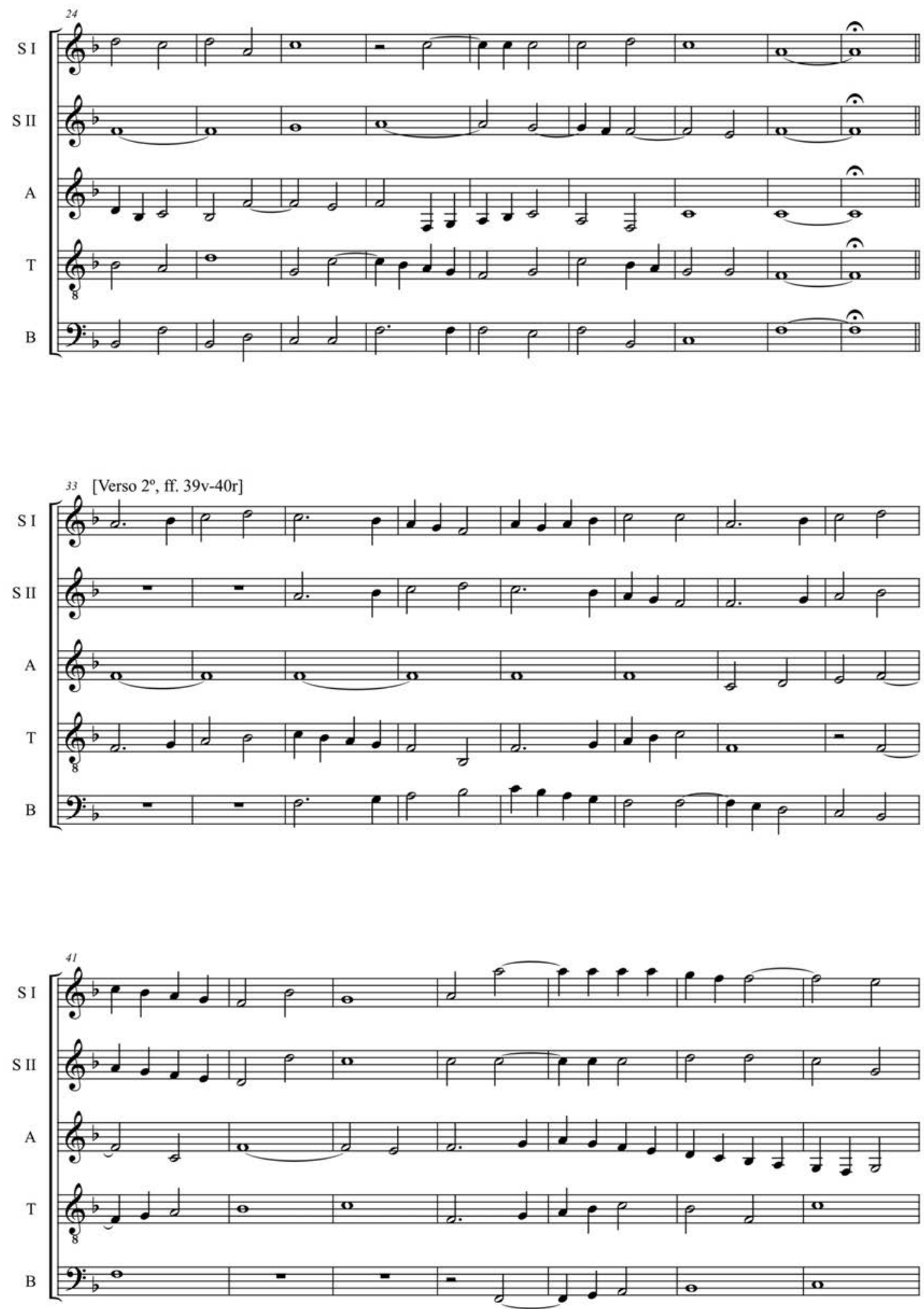

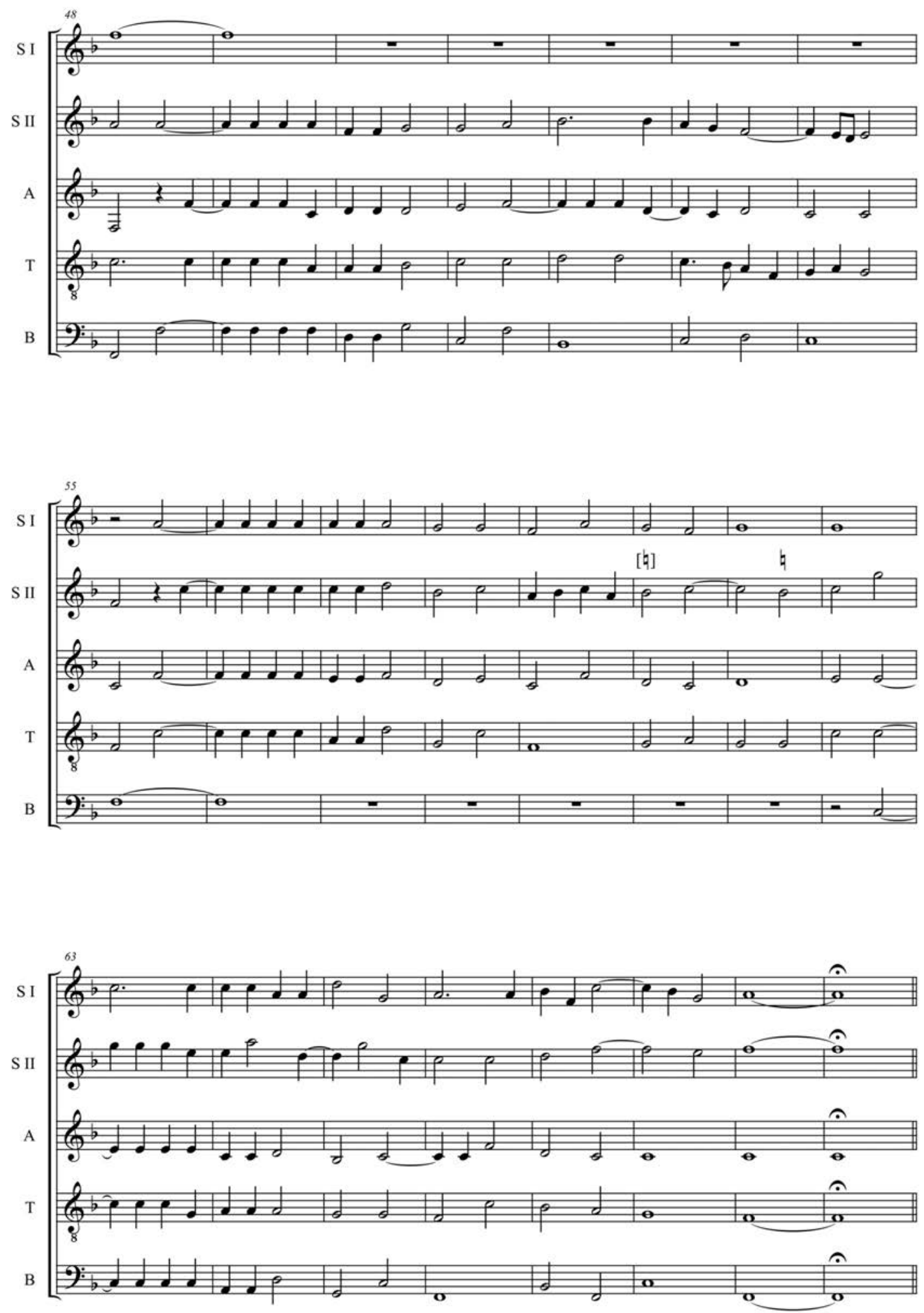

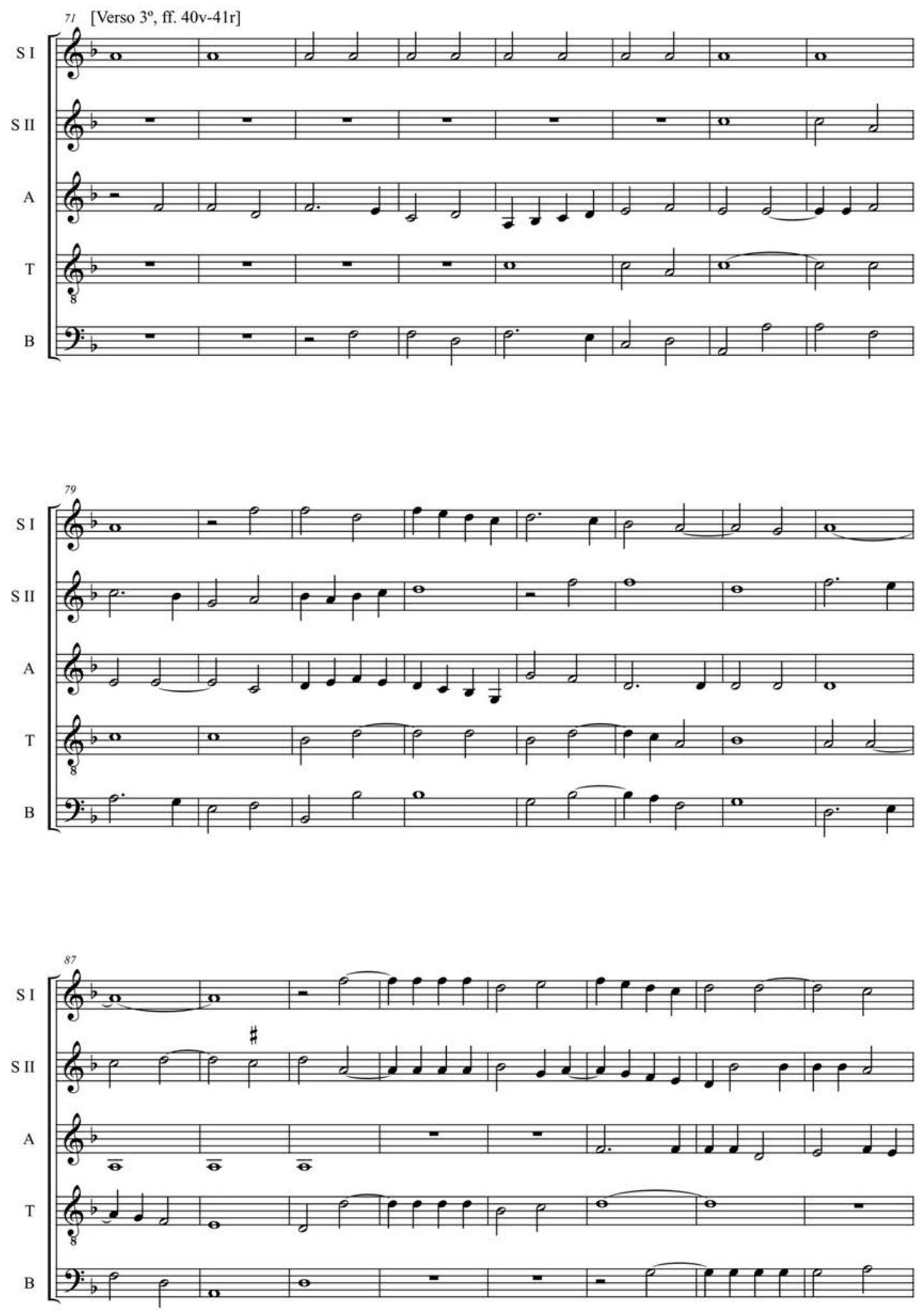

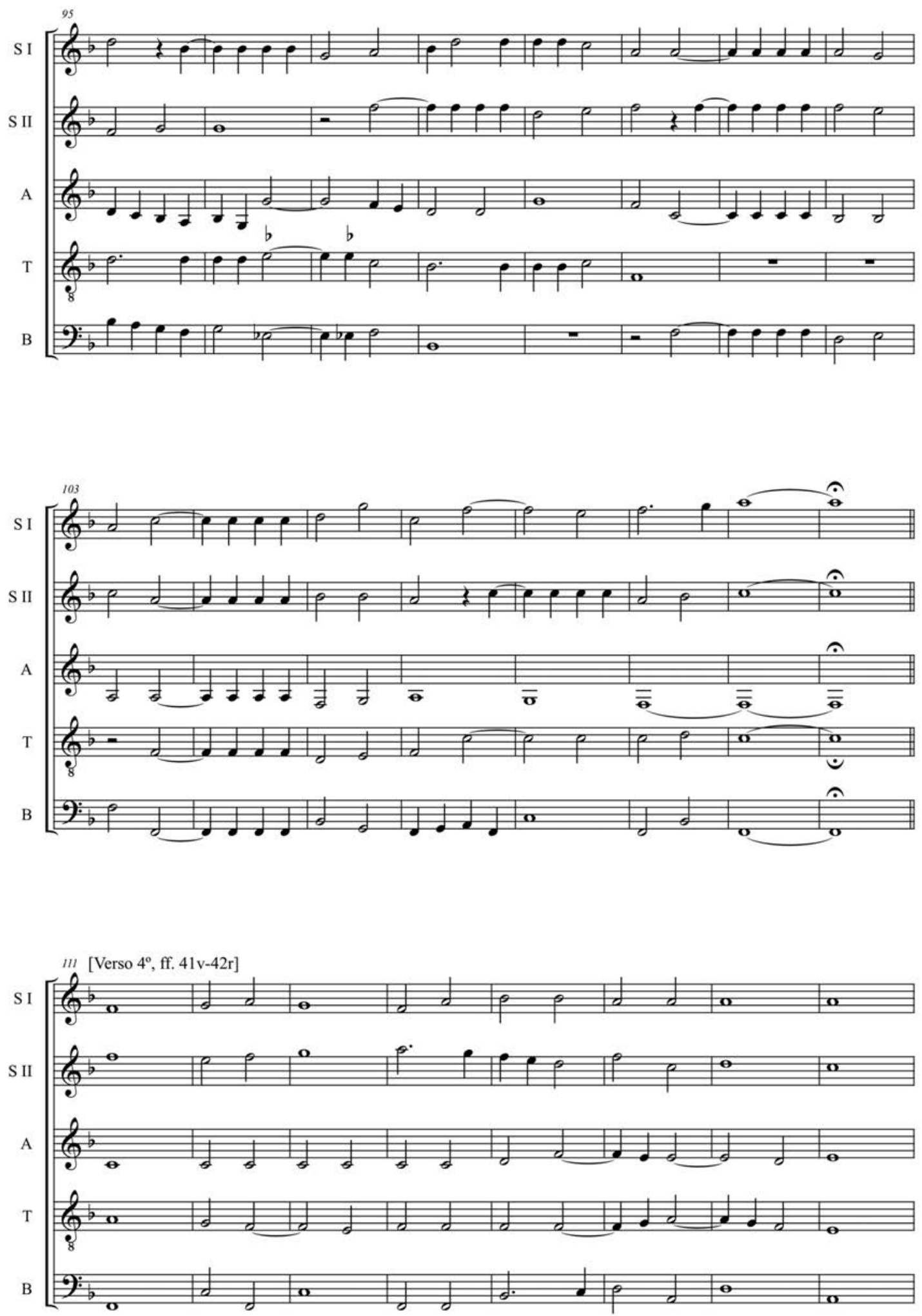

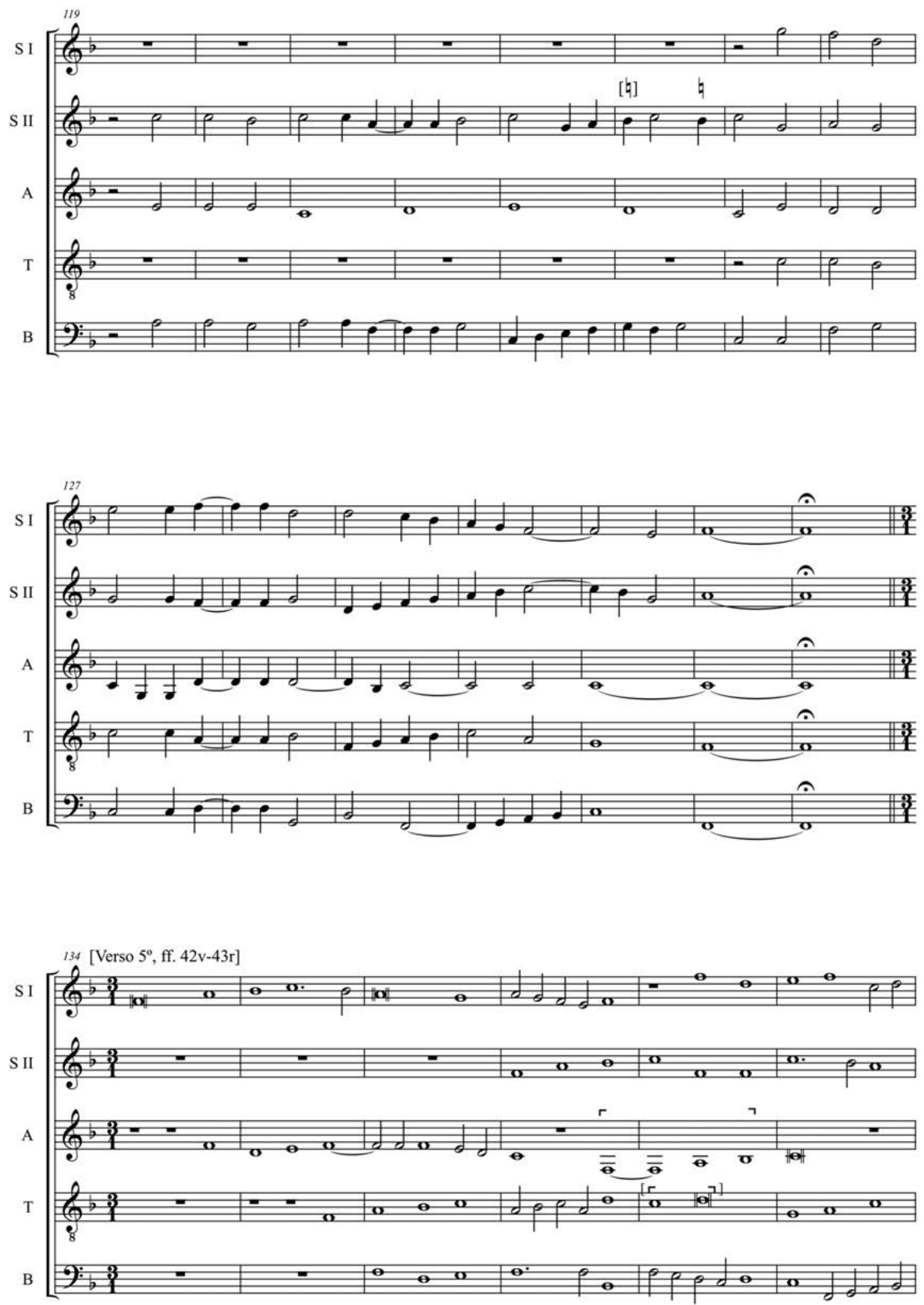

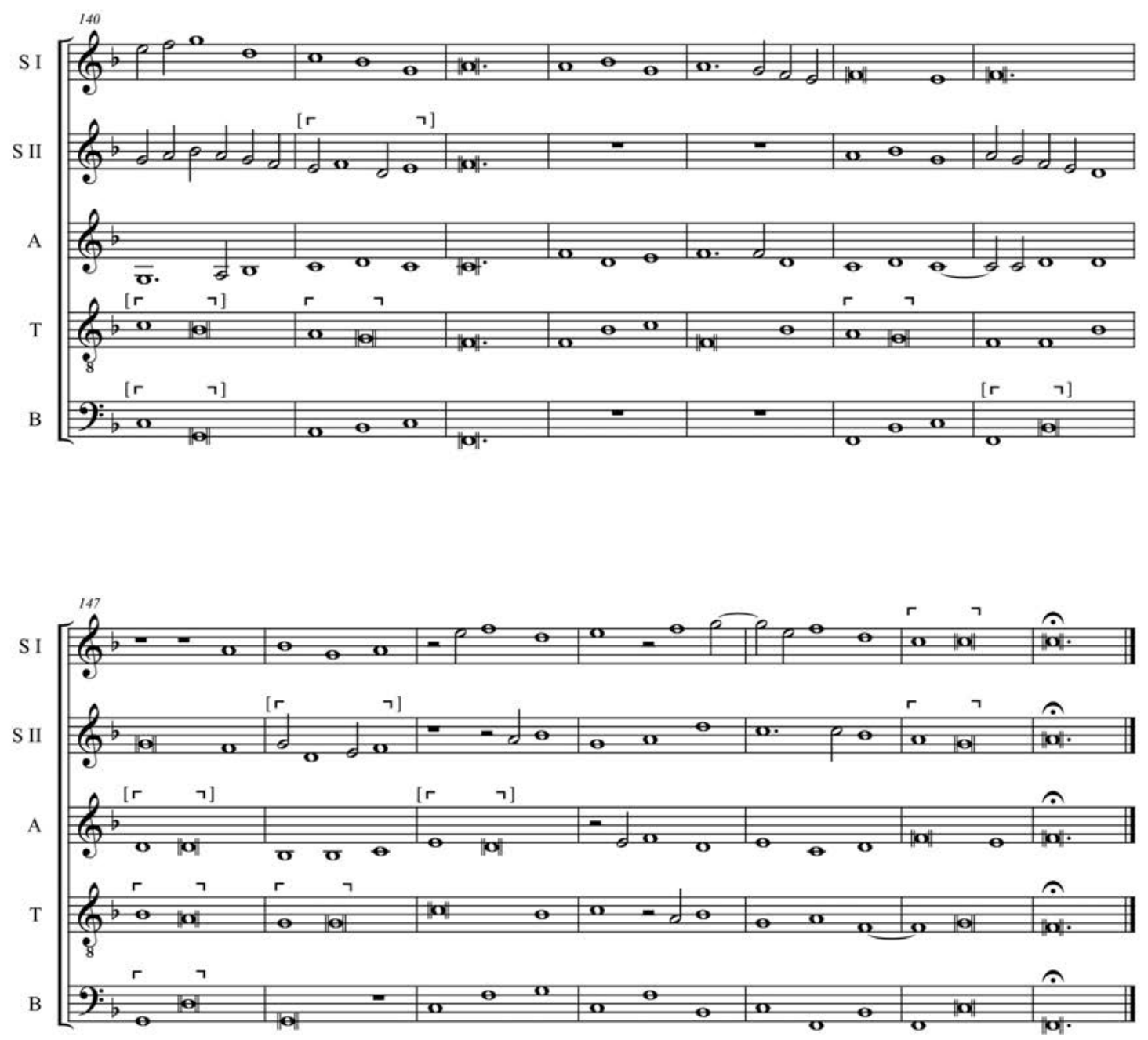


\section{BIBLIOGRAFÍA}

Aizpurúa Zalacaín, Pedro, 1982: “Juan Navarro en la Catedral de Valladolid". Revista de Musicología, vol. 5/2, 339-345.

Álvarez Solar-Quintes, Nicolás, 1953: "Morales en Sevilla y Marchena. Estampa de una época”. Anuario musical, vol. 8, 27-38.

Annibaldi, Claudio, 1993: La musica e il mondo. Mecenatismo e committenza musicale in Italia tra Quattro e Settecento. Bolonia, Il Mulino.

Bejarano Pellicer, Clara, 2013: El mercado de la música en la Sevilla del Siglo de Oro. Sevilla, Universidad de Sevilla y Fundación Focus-Abengoa.

Black, Christopher F., 1989: Italian Confraternities in the Sixteenth Century. Cambridge, Cambridge University Press.

Blackburn, Bonnie, 1992: "Music and Festivities at the Court of Leo X: A Venetian View". Early Music History, vol. 11, 1-37.

Burgess, Clive y Wathey, Andrew, 2005: "Cartografías del paisaje sonoro: la música sacra en las ciudades inglesas, 1450-1550". En Bombi, Andrea; Carreras, Juan José; y Marín, Miguel Ángel (eds.), Música y cultura urbana en la Edad Moderna. Valencia, Universitat de València, 69-105.

Caballero Venzalá, Manuel y Almansa Tallante, Rufino, 2009: Diccionario Bio-Bibliográfico del Santo Reino de Jaén. Jaén, Instituto de Estudios Giennenses.

Corral Báez, Francisco Javier, 1999: "Guadix”. En Casares Rodicio, Emilio (dir.), Diccionario de la música española e hispanoamericana. 10 vols. Madrid, SGAE, vol. 5, 915-926.

Covarrubias, Sebastián de, 1611: Tesoro de la lengua castellana o española. Madrid, Luis Sánchez.

De Vicente, Alfonso, 2007: "Música, propaganda y reforma religiosa en los siglos XVI y XVII: cánticos para la 'gente del vulgo' (1520-1620)". Studia Aurea, 1 [<http://www.studiaaurea.com $>$ ].

Fabronius, Angelo, 1797: Leonis X Pontificis Maximi Vita auctore Angelo Fabronio Acadamiae Pisanae Curatore. Pisa, A. Landius.

Fiorentino, Giuseppe, 2013: “Cantar 'por uso' y cantar 'por razón': tradiciones orales de polifonía en la España del Renacimiento". En Marín López, Javier et al. (eds.), Musicología global, musicología local. Madrid, Sociedad Española de Musicología, 1854-63.

Galera Andreu, Pedro, 2012: "Don Francisco de los Cobos, magnificente y virtuoso". En Camacho Martínez, Rosario y Asenjo Rubio, Eduardo (eds.), Patronos y modelos en las relaciones entre Andalucía, Roma y el Sur de Italia. Málaga, Universidad de Málaga, 89134.

García de Quesada y Martínez, Manuel, 1950: La Santa Capilla de S. Andrés. Jaén, s.e.

Glixon, Jonathan, 2003: Honoring God and the City: $M u$ sic at the Venetian Confraternities, 1260-1807. Nueva York, Oxford University Press.

Gómez Muntané, Maricarmen, 1996: "La música laica en el reino de Castilla en tiempos del Condestable Don Miguel Lucas de Iranzo". Revista de Musicología, vol. 19/1-2, 25-45.

Gómez Pintor, María Asunción, 1995: "Fuentes documentales inéditas sobre la figura del polifonista Juan Navarro, El Hispalensis". Cuadernos de Arte de la Universidad de Granada, vol. 26, 27-46.

Gómez Pintor, María Asunción, 2000: "Navarro, Juan (II)". En Casares Rodicio, Emilio (dir.), Diccionario de la música española e hispanoamericana. 10 vols. Madrid, SGAE, vol. 7, 992-994.

González Barrionuevo, Herminio, 2000: Francisco Guerrero (1528-1599). Vida y obra. La música en la catedral de Sevilla a finales del siglo XVI. Sevilla, Cabildo Metropolitano de la Catedral de Sevilla.

González López, Luis, 1960: "La Santa Capilla de S. Andrés". Paisaje, s/n, 2119-23.

González Marín, Luis Antonio, 1993: “Dos nuevas piezas españolas del siglo XVII para conjunto instrumental". Nassarre, vol. 9/2 (1993), 211-219.

González Marín, Luis Antonio, 2010: "Regir la capilla o el oficio de director antes de que existieran los directores". Quodlibet, vol. 46, 81-117.

Hagg, Barbara, 1992: "The meeting of sacred ritual and secular piety: endowments for music". En Knighton, Tess y Fallows, David (eds.), Companion to Medieval and Renaissance Music. Londres, J. M. Dent \& Sons, 60-68.

Higueras Maldonado, Juan, 1985: “Documentación latina en el archivo de la Santa Capilla de San Andrés". Actas de la I Asamblea de Estudios Marianos. Jaén, Universidad de Jaén y Cajasur, 241-302.

Jiménez Cavallé, Pedro, 1983: "Francisco Ruiz, maestro de capilla en la Catedral de Jaén de 1565 a 1598". Guadalbullón, vol. 1,9-22.

Jiménez Cavallé, Pedro, 1987: "La música en la Santa Capilla de San Andrés. Notas históricas". Boletín del Instituto de Estudios Giennenses, vol. 129, 9-31.

Jiménez Cavallé, Pedro, 1990: "Los inventarios de música de la Catedral de Jaén en los siglos XVI y XVII". Senda de los Huertos, vol. 17, 67-76. 
Jiménez Cavallé, Pedro, 1991: La música en Jaén. Jaén, Diputación Provincial de Jaén.

Jiménez Cavallé, Pedro, 1996: "Francisco Carrillo, organista y canónigo de la Catedral de Jaén (1580-1620?). Notas biográficas". Nassarre, vol. 12/2, 185-195.

Jiménez Cavallé, Pedro, 1998: Documentario Musical de la catedral de Jaén. I. Actas capitulares. Granada, Centro de Documentación Musical de Andalucía.

Jiménez Cavallé, Pedro, 2007: "Música renacentista en Jaén”. En Rincón González, María Dolores (ed.), Doce calas en el Renacimiento y un epílogo. Jaén, Universidad de Jaén, 317-348.

Jiménez Patón, Bartolomé, 1628: Historia de la antigua y continuada nobleza de la ciudad de Jaén. Jaén, Pedro de la Cuesta.

Kirk, Douglas, 1993: Churching the Shawms in Renaissance Spain: Lerma, Archivo de San Pedro MS. Mus. 1. Tesis doctoral, 2 vols. McGill University.

Kirk, Douglas, 2014: "Instrumentistas modernos que evocan el sonido de los ministriles de Granada del siglo XVI y Puebla del siglo XVII". Revista de Musicología, vol. 37/2, 663-671.

Kirsch, Winfried, 2001: "De Silva, Andreas". Grove Music Online [<http://www.oxfordmusiconline.com>].

Knighton, Tess, 1997: "Spaces and contexts for listening in 15th-century Castile: the case of the Condestable's palace in Jaén". Early Music, vol. 25/4, 661-677.

Knighton, Tess, 2002: "Ribera [Ribeira], Antonio de". En Casares Rodicio, Emilio (dir.), Diccionario de la música española e hispanoamericana. 10 vols. Madrid, SGAE, vol. 9, 170-171.

Knighton, Tess, 2002: "Francisco de Peñalosa: New Works Lost and Found". En Crawford, David y Wagstaff, Grayson (eds.), Encomium Musicae. Essays in Memory of Robert J. Snow. Hillsdale, Pendragon Press, 231-257.

Knighton, Tess, 2007: "Morales in Print: Distribution and Owership in Renaissance Spain”. En Rees, Owen y Nelson, Bernadette (eds.), Cristóbal de Morales. Sources, Influences, Reception. Woodbridge, The Boydell Press, 161-175.

Kreitner, Kenneth, 2009: "The repertory of the Spanish cathedral bands". Early Music, vol. 37/2, 267-286.

Libro de los Estatutos de la Santa Capilla y Noble Cofradía de la Limpia Concepción de Nuestra Señora la Virgen María, sita en la Iglesia Parroquial de San Andrés. Madrid, Imprenta de D. A. Pérez Dubrull, 1882.

Llordén, Andrés, 1961: "Notas históricas de los maestros de capilla y organistas, mozos de coro y seises de la Ca- tedral de Málaga (1498-1583)". Anuario Musical, vol. $16,99-148$.

Llordén, Andrés, 1977: "Notas históricas de los maestros de capilla de la Colegial de Antequera". Anuario Musical, vols. 31-32, 115-165.

Llorens Cisteró, José María, 1957: “Juan Escribano, cantor pontificio y compositor". Anuario Musical, vol. 12, 96-122.

López Arandia, María Amparo, 1995: Catálogo documental de la Santa Capilla de San Andrés de Jaén. Jaén, inédito.

López Arandia, María Amparo, 2007: Rinascimento y Reformatio. El proyecto de Gutierre González en Jaén. Jaén, Universidad de Jaén.

López Arandia, María Amparo, 2010: "De Castilla a Michoacán. La obra de Gutierre González en la educación del siglo XVI". Revista de Antropología Experimental, vol. 10, 129-147 [<http://revista.ujaen.es/rae>].

López Molina, Manuel, 1997: “Ministriles en Jaén en 1619”. Boletín del Instituto de Estudios Giennenses, vol. 167, 345-351.

López Molina, Manuel, 1998: "De la música en los entierros en el Jaén del siglo XVII". Boletín del Instituto de Estudios Giennenses, vol. 168, 57-61.

López Molina, Manuel, 2001: “Compañía de ministriles en Jaén en el año 1586". Senda de los Huertos. Revista Cultural de la Provincia de Jaén, vols. 61-62, 93-96.

López Pérez, Manuel, en prensa: La Santa Capilla de S. Andrés, un monumento ignorado. Jaén.

López-Calo, José, 1963: La música en la Catedral de Granada en el siglo XVI. 2 vols. Granada, Fundación Rodríguez Acosta.

López-Calo, José, 2005: Documentario musical de la Capilla Real de Granada. Vol. 1. Actas capitulares. Granada, Centro de Documentación Musical de Andalucía.

Marín López, Javier, 2007: "Un tesoro musical inexplorado: los libros de polifonía de la Catedral de Baeza". En Moreno Moreno, María Águeda (ed.), Estudios de Humanismo Español. Baeza en los siglos XVI y XVII. Baeza, Ayuntamiento de Baeza, 319-346.

Marín López, Javier, 2010: "Patrones de diseminación de la música catedralicia andaluza en el Nuevo Mundo (ss. XVI-XVIII)". En García-Abasolo, Antonio (ed.), La música en las catedrales andaluzas y su proyección en América. Córdoba, Universidad de Córdoba y CajaSur, 95-132.

Marín López, Javier, 2015: "Music Books for an 'iglesia principal y calificada': the 1657 Inventory of Jaén Cathedral in Context". En Knighton, Tess y Ros-Fábregas, Emilio (eds.), Recent Research in Early Iberian 
Music in an International Context. Kassel, Reichenberger, 108-160.

Marín López, Javier y Sánchez López, Virginia (eds.), 2012: Paisajes sonoros urbanos. XVII Festival de Música Antigua de Úbeda y Baeza. Baeza, Festival de Música Antigua.

Marín López, Miguel Ángel, 2002: "Una historia imposible. Música y devoción en Úbeda durante el Antiguo Régimen". En Moreno Mendoza, Arsenio y Almansa Moreno, José Manuel (eds.), Úbeda en el siglo XVI. Úbeda, Fundación Renacimiento y Editora El Olivo, 141-166.

Martínez Gil, Carlos, 2008: "El magisterio de capilla en las catedrales y colegiatas de España: orígenes, configuración e importancia en la Edad Moderna”. Memoria ecclesiae, vol. 31, 131-172.

Mozas Mesa, Manuel, 1925: Una institución giennense del siglo XVI: la Santa Capilla de S. Andrés. Jaén, Tip. El Pueblo Católico.

Nieto Cumplido, Manuel, 2004: "La música en la Catedral de Córdoba (1236-1577)". En Moreno Calderón, Juan Miguel (ed.), El Patrimonio histórico-musical de Córdoba. II Jornadas sobre Patrimonio. Córdoba, Área de Cultura del Excmo. Ayuntamiento, 59116.

Noone, Michael, 2003: Códice 25 de la Catedral de Toledo. Polifonía de Morales, Guerrero, Ambiela, Boluda, Josquin, Lobo, Tejeda, Urrede y Anónimos. Madrid, Fundación Caja de Madrid y Alpuerto.

Noone, Michael, 2007: "Printed Polyphony acquired by Toledo Catedral, 1532-1669”. En Fenlon, Iain y Knighton, Tess (eds.), Early Music Printing and Publishing in the Iberian World. Kassel, Reichenberger, 241-274.

O’Regan, Noel, 1994: "Music at the Roman Archconfraternity of San Rocco in the Last Sixteenth Century". En Antolini, Bianca Maria; Morelli, Arnaldo; y Spagnolo, Vera Vita (eds.), La musica a Roma atraverso le fonti d'archivo. Atti del Convegno Internazionale - Roma 4-7 giugno 1992. Luca, Libreria Musicale Italiana, 521-552.

O'Regan, Noel, 1994: "Victoria, Soto and the Spanish Archconfraternity of the Resurrection in Rome". Early Music, vol. 22/2, 279-295.

O'Regan, Noel, 1995: Institutional Patronage in Post-Tridentine Rome: Music at Santissima Trinita dei Pellegrini 1550-1650. Londres, Royal Music Association.

Ortega Sagrista, Rafael, 1961: “Arte y artistas en la Santa Capilla”. Boletín del Instituto de Estudios Giennenses, vol. 30, 23-63.
Pérez-Mancilla, Victoriano, 2013: "Historiografía musical de las parroquias en España: estado de la cuestión". Anuario Musical, vol. 68, 47-80.

Pietschmann, Klaus, 1999: "Músicos y conjuntos musicales en las fiestas religiosas de la Iglesia nacional española de Santiago en Roma antes del Concilio de Trento". Anthologica Annua, vol. 46, 451-476.

Pirro, André, 1935: "Leo X and Music". Musical Quarterly, vol. 21/1, 1-16.

Preciado, Dionisio, 1986-1991: Francisco de Peñalosa. Opera omnia, 4 vols. Madrid, Sociedad Española de Musicología.

Querol, Miguel, 1988: "El humanismo musical español”. Nassarre, vol. 4/1-2, 213-225.

Robledo, Luis, 1998: "La música en el pensamiento humanista español". Revista de Musicología, vol. 21/2, 385430.

Ros-Fábregas, Emilio, 2001-2002: "Libros de música en bibliotecas españolas del siglo XVI (I-III)". Pliegos de Bibliofilia, vols. 15, 16 y 17, 39-62, 33-46 y 17-54.

Ruiz Jiménez, Juan, 2004: “Ministriles y extravagantes en la celebración religiosa". En: Griffiths, John y Suárez-Pajares, Javier (eds.), Políticas y prácticas musicales en el mundo de Felipe II. Madrid, ICCMU, 199-239.

Ruiz Jiménez, Juan, 2014: "Música tras la muerte: dotaciones privadas y espacios rituales en la Catedral de Sevilla (siglos XIII-XVI)". Revista de Musicología, vol. 37/1 (2014), 53-88.

Saldoni, Baltasar, 1868-81: Diccionario biográfico-bibliográfico de efemérides de músicos españoles. 4 vols. Madrid, Isidro Torres.

Sherr, Richard, 1982: "A Note on the Biography of Juan del Encina”. Bulletin of the Comediantes, vol. 34, 159-172.

Sherr, Richard, 1992: "The 'Spanish Nation' in the Papal Chapel, 1492-1521”. Early Music, vol. 20/4, 601-609.

Sherr, Richard, 2001: "Rome. 2. The Renaissance (14201600)". Grove Music Online [<http://www.oxfordmusiconline.com $>$ ].

Snow, Robert J., 1987: "Music by Francisco Guerrero in Guatemala". Nassarre, vol. 3/1, 153-202.

Stanford, Thomas y Spiess, Lincoln, 1969: An Introduction to certain mexican musical archives. Detroit, Information Coordinators.

Starr, Pamela F., 1997: "Josquin, Rome, and a Case of Mistaken Identity”. The Journal of Musicology, vol. 15/1, 43-65.

Stevenson, Robert, 1970: Renaissance and Baroque Musical Sources in the Americas. Washington, D.C., Organization of the American States. 
Stevenson, Robert, 1993: La música en las catedrales españolas del Siglo de Oro. Madrid, Alianza.

Stevenson, Robert, 2001: "Navarro, Juan (I)". Grove Music Online [<http://www.oxfordmusiconline.com $>$ ].

Suárez-Pajares, Javier, 2004: "Dinero y honor: aspectos del magisterio de capilla en la España de Francisco Guerrero". En Griffiths, John y Suárez-Pajares, Javier (eds.), Políticas y prácticas musicales en el mundo de Felipe II. Madrid, ICCMU, 149-197.

Vega, María José, 2007: "La unión de poesía y música en el Renacimiento: breve historia". En Rincón González, María Dolores (ed.), Doce calas en el Renacimiento y un epílogo. Jaén, Universidad de Jaén, 269-316.
Zauner, Sergi, 2015: "El fabordón hispánico como res facta salmódica a comienzos de la Edad Moderna. Ensayo terminológico". Revista de Musicología, vol. 38/1, 4777.

\section{DISCOGRAFÍA}

Ministriles Novohispanos. Obras del manuscrito 19 de la Catedral de Puebla de los Ángeles, Ensemble La Danserye. CD. Madrid, Sociedad Española de Musicología, serie "El patrimonio musical hispano" no 31 , DISCAN/DCD309, 2013.

Recibido: 23.07.2015

Aceptado: 08.06.2017 